\title{
Denizli ve Çevresinde Yer Alan Bazı Câmilerin Yapı Elemanlarının Değerlendirmesi
}

Nilgün Çevrimli*

\begin{abstract}
Öz
Denizli ve çevresinde bulunan birçoğu vakıf yapısı olarak inşa edilen, bilgi ve belgelerine ulaşılabilen bir grup cami, yapı elemanları açısından düz tavanlı ve kubbeli camiler olarak gruplandııılması sonrası yetmiş bir düz tavanlı, beş kubbeli cami tespit edilmiştir. Düz tavanlı camiler de kendi içerisinde göbeksiz, tekne tavanlı, kubbeli tavanlı, kademeli tavanlı, çıtalı göbekli tavanlı ve tonozlu tavanlı şeklinde sınıflandırılmaya gidilmiştir. Her iki ana grup düz tavanlı ve kubbeli camiler; örtü düzeni ve taşıyıcı elemanlar, malzeme ve teknik bakımından incelenmiştir. İncelenen eserlerin en erken tarihlisi 13.yüzyıl, en geç tarihlisi ise 20.yüzyılın ikinci yarısına tarihlenmektedir. Çalışma yöredeki benzer yapılardaki yapı elemanları ile ilgili genel bir fikir vermesi ve bazı yapıların ilk kez belgelenmesi açısından oldukça önem arz etmektedir.
\end{abstract}

Anahtar Kelimeler: Denizli, Câmi, örtü sistemi, tavan, ahşap, tavan göbeği, kubbe, sınıflandırma, yapı, mimari.

\section{The Evaluation of a Group of Mosques in Denizli and Its Environs in Relation to the Structure Elements}

\begin{abstract}
In this study, a group of mosques have been identified and examined many of which were built as waqfs in Denizli centre and surrounding regions. These mosques are classified into two groups depending on their building structures; whether they have flat ceilings or domes. There are 71 mosques with flat ceiling and 5 with domed structure. The mosques with flat ceilings are classified among themselves as boat ceilings, vaulted ceilings, stepped ceilings, slatted ceilings and core vaulted ceilings. Both groups of mosques were examined in terms of layout, cover material, load-bearing structural elements, construction materials and techniques. The oldest of the mosques dates back to 13th century, while the latest work is dated to the second half of the 20th century. Study is quite important as it documents common characteristics of similar mosques in terms of structural properties and it reports some of the mosques in the region for the first time.
\end{abstract}

Key Words: Denizli, mosque, cover system, ceiling ,wooden, ceiling belly dome, classicifiation, structure, architecture. 


\section{Giriş}

Denizli'nin tarihteki yeri ve önemi ile ilgili çok sayıda çalışmanın varlığı bilinmektedir. Ancak Sanat Tarihi Araştırmaları bakımından konu ele alındığında, önceki dönemlerde Selçuklu Dönemi yapılarından Akhan ve Çardak Han hakkında yeterli araştirmalar yapıldığı, ancak geç dönem yapılarına ait araştırmaların ise yok denecek kadar az olduğu anlaşılır. Bununla birlikte son yıllarda Denizli ve çevresinde bulunan Selçuklu, Beylikler ve Osmanlı Dönemlerine ait dini mimariden câmi, tekke, türbe; sivil mimari örneklerden han, hamam, sarnıç, köprü, çeşme gibi yapılarla ilgili çalışmaların arttğı gözlemlenir.

Çalışmamıza konu olan bazı yapılarla ilgili en kapsamlı çalışma 1991 yılında, Şakir Çakmak tarafindan yapıların plan, malzeme, teknik ve süsleme bakımından incelendiği "Denizli ili'ndeki Türk Anıtları" adlı yüksek lisans tezidir. Bu bağlamda Kasım İnce'ye ait Vakıflar Genel Müdürlüğü Arşivi'ndeki Babadağ'a Ait Vakfiyeler ve Babadağ'daki Türk Eserleri (1999), Yukarı Câmii/Akköy-Denizli (2001), Tavas ve Çevresindeki Osmanlı Mimarî Eserleri (2003) adlı bildiri ve makaleler de yöredeki eserlerin tespiti açısından önemli çalışmalardır. Ayrıca Kadir Pektaş'ın Denizli Çevresindeki Türk Dönemi Tarihi Eserleri (2003a), Acıpayam ve Çevresindeki Türk Dönemi Eserlerinden Bir Kesit (2003b) adlı çalışmaları ile Saim Cirtil'in Denizli Türbeleri (2006), Çivril Bayat Köyü Câmi (2007); Nazlı İpek Mavuşoğlu’nun "Savranşah Köyü Câmi Restorasyon Projesi" (2008) adlı yüksek lisans tezleri gibi bölge yapılarının yapıların ele alındığı genel ya da monoğrafik çalışmalar mevcuttur.

Çalışmamızda Denizli ve Yöresinde bulunan, henüz hiçbir yayında yer almayan, tespiti tarafimızdan yapılmış ${ }^{1}$ geç döneme ait düz ahşap tavanlı bazı câmilerle Vakıflar Genel Müdürlüğü Arşivin-

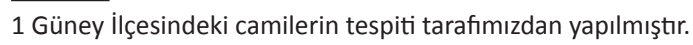

$\mathrm{de}^{2}$ vakıf yapısı olanlara ait bilgi ve belgeleri mevcut olan yetmiş altı câmi, yapı elemanları açısından bütüncül bir anlayışla ele alınıp incelenmiştir. Bu çerçevede tarafimızdan irdelenen söz konusu yapıların, yapı elemanları ana başlığı altında örtü sistemleri esas alınarak 1- Düz tavanlı, 2- Kubbeli şeklinde tasnif edilmiş ve yapılar yapıldıkları yer ve tarihlere göre sıralanmışlardır.

Düz tavanlı câmiler de kendi içerisinde yine örtü sistemine göre; Düz göbeksiz tavanlı, düz çökertme tekne göbekli tavanlı, düz çıtalama göbekli tavanlı, düz -kubbeli tavanlı, düz tonozlu tavanlı ve düz-kademeli tavanlı câmiler şeklinde alt başlıklarla tanımlanmışlardır. Bu gruplarda yer alan yapılar yapım yeri ve tarihi bakımından irdelenirken, yapı elemanları taşıyıcılar (duvarlar, destekler), örtü düzeni, malzeme ve teknik şeklinde ayrı başlıklar altında karşılaştırmalı olarak incelenmiştir. İncelenen toplam yetmiş alt eserin en erken tarihlisi 13.yüzyıl en geç tarihlisi ile 20.yüzyılın ikinci yarısına tarihlenmektedir.

\section{Denizli Ve Çevresinde Yer Alan Bazı Ahşap Ta- vanlı Câmiler Ve Yapı Elemanları}

\section{1- Düz Tavanlı Câmiler}

Anadolu'da düz tavanlı ya da düz ahşap tavanlı, ahşap direkli câmi inşa etme geleneğinin Anadolu Selçukluları'nın ardından beylikler döneminde devam ettiği bilinmektedir. Bu dönemde Ankara, Konya, Beyşehir, Kastamonu, Niğde ve Afyonkarahisar başta olmak üzere Anadolu'nun birçok yöresinde ahşap direkli ve tavanlı câmilerle karşılaşılır. (Kuran, 1972: 182; Önge, 1975:181-184; Eskici, 1998:110-113; Erdemir, 1999:109; Çal, 2003: 3-8, 28; Uysal, 2001).

Araştırma kapsamında Denizli ve çevresinde gerek yerinde inceleme gerekse belgelerine ulaşı bilinen toplam 71 adet düz tavanlı yapı tespit edilmiş olup, tarih sıralamasına göre aşağıda listelenmiştir.

2 Vakıflar Genel Müdürlüğü Arşivi metin içerisinde VGMA olarak kısaltılmıştır. 
Tablo 1. Düz Tavanlı Ahşap Câmiler

\begin{tabular}{|c|c|c|c|}
\hline 1 & Tavas & Ulukent (Mescidi) Câmi & $1530 \mathrm{M}$. \\
\hline 2 & Kızılcabölük & Hanönü Câmi & 1697 M./H.1109 \\
\hline 3 & Tavas & Ali Ağa Câmi & 1733M./H.1146 \\
\hline 4 & Bekilli & Çoğaşlı Köyü Câmi² & 1743 M./H. 1156 \\
\hline 5 & Güney & Çarşı Câmi & 1747-48 М./H.1161 \\
\hline 6 & Baklan & Boğaziçi Köyü Eski Câmi & 1774-75 М./H.1186 \\
\hline 7 & Sarayköy & Çarşı Câmi & (18.yy), \\
\hline 8 & Çivril & Savran Köyü Serbanşah Câmi & 18. Yüzyılın üçüncü çeyreği \\
\hline 9 & Baklan & Tekke Câmi & 18.yüzyıl sonu 19.yüzyıl başı \\
\hline 10 & Çal & Kuyucak Köyü Câmi ${ }^{4}$ & $1893-94$ \\
\hline 11 & Güney & Hacı Habib Câmi & 1796M./H.1211 \\
\hline 12 & Akköy & Yukarı Câmi & 18.yy.sonu-19.yybaşı \\
\hline 13 & Baklan & Çataloba Köyü Câmi & 18.yy-sonu-19.yy başı \\
\hline 14 & Çivril & Bayat Köyü Câmi & 1872 \\
\hline 15 & Çal & Kocaköy Şalvan Câmi & 19.yy.başı \\
\hline 16 & Babadağ & Kırcıtaş Mescidi/Câmi & 1801-1802 M./H.1216 \\
\hline 17 & Acıpayam & Yazır Çarşı Câmi & 1802 M./H.1217 \\
\hline 18 & Güney & Dere Câmi & 1802 M./H.1227 \\
\hline 19 & Güney & El-Hac Hasan ibn el-Hac Halilzade Câmi & 1803M./H.1218 \\
\hline 20 & Tavas & Yukarı Câmi & 1810-1820 М./H.1225 \\
\hline 21 & Yatağan & Teke Müsellim Câmi & 1811 M./H.1266 \\
\hline 22 & Bozkurt & Baklankuyucak Köyü Câmi & 1814-15 M. \\
\hline 23 & Kale & Cevher Paşa Câmi & 1819-20 M./H.1235 \\
\hline 24 & Babadağ & Düvenönü Câmi & 1842M./H.1258 \\
\hline 25 & Serinhisar & Ağalar (Hacı Hamza) Câmi & 1859 M./H.1276 \\
\hline 26 & Tavas & Çarşı Câmi & 1860 M./H.1277 \\
\hline 27 & Kale & Pazaryeri Câmi & 1867 М./H.1284 \\
\hline 28 & Güney & Hacı Hüseyin Câmi & $1867 \mathrm{M}$ \\
\hline 29 & Tavas & Dedeli Câmi & 1871 М./Н.1288 \\
\hline 30 & Denizli & Kuşpınar Hasan Fevzi Efendi Câmi & $1872 \mathrm{M}$. \\
\hline 31 & Güney & Belenardıç Köyü Câmi & $1884 \mathrm{M}$. \\
\hline 32 & Çivril & Gümüşsu Dere Câmi & 19.yy. \\
\hline 33 & Tavas & Çayırlık Câmi & 19.yy.2.yarı. \\
\hline 34 & Tavas & Kavaklı Câmi & 19.yy.2.yarı. \\
\hline 35 & Tavas & Aydoğdu Köyü Câmi & 19.yy.2.yarı. \\
\hline 36 & Tavas & Paşalılar Câmi & 1899 М./Н.1317 \\
\hline
\end{tabular}




\begin{tabular}{|c|c|c|c|}
\hline 37 & Tavas & Mestan Ağa Câmi & 19.sonu-20.yy başı \\
\hline 38 & Denizli & Ulu Câmi & 1920 tamirat \\
\hline 39 & Denizli & Kiremitçi Câmi (Darıverenli) & \\
\hline 40 & Denizli & İncekara Câmi & \\
\hline 41 & Denizli & Saray Mahallesi Hacılar Câmi & \\
\hline 42 & Denizli & Pelitlibağ Câmi & 20.yy. \\
\hline 43 & Denizli & Akkonak Câmi & \\
\hline 44 & Denizli & Öküz batt Mescidi & \\
\hline 45 & Denizli & Odun Pazarı Câmi & 1923 \\
\hline 46 & Denizli & Saltak Câmi & \\
\hline 47 & Denizli & Değirmenci Câmi & \\
\hline 48 & Güney & Çolacık Câmi & 20.yy başı \\
\hline 49 & Güney & Said Ağa Câmi & 20.yy. başı \\
\hline 50 & Güney & Mestan Câmi & 20.yy başı \\
\hline 51 & Buldan & Dört Eylül Câmi & 20.yy başı \\
\hline 52 & Buldan & Hacı Bekir Câmi & 20.yy başı \\
\hline 53 & Buldan & Çarşı Câmi & 20.yy başı \\
\hline 54 & Buldan & Gür oluk Câmi & 20.yy başı \\
\hline 55 & Buldan & Karşıyaka Câmi & 20.yy başı \\
\hline 56 & Buldan & Şükür Cami & \\
\hline 57 & Babadağ & Hamidiye Câmi & 1901-1902 \\
\hline 58 & Sarayköy & Hükümet Önü Câmi & 1906 \\
\hline 59 & Babadağ & Aşağı Tepeardı Câmi & 1906M./H.1323 \\
\hline 60 & Babadağ & Yukarı Kuzere Ahmet Paşa Câmi & 20.yy başı \\
\hline 61 & Tavas & Avdan Baba Câmi ${ }^{8}$ & 1909 M./H.1327 tamir \\
\hline 62 & Acıpayam & Ova yurt/ Taraş Köyü Câmi & 1910 \\
\hline 63 & Acıpayam & Apa Köyü Câmi & \\
\hline 64 & Acıpayam & Yassıhöyük Eski Câmi & 1942 tamir \\
\hline 65 & Denizli & Hacı Kaplan Câmi & \\
\hline 66 & Denizli & Hatipoğlu Câmi & \\
\hline 67 & Çardak & Gemiş Câmi & \\
\hline 68 & Çardak & Söğüt Köyü Câmi & \\
\hline 69 & Çivril & İğdir Köyü Câmi & \\
\hline 70 & Sarayköy & Hisar köy & \\
\hline 71 & Sarayköy & Hasköy & \\
\hline
\end{tabular}




\section{1. Örtü Sistemi}

Düz tavanlı câmilerde örtü sistemine bakıldığında günümüzde genellikle dıştan kırma çat şeklindedir ve kiremit kaplıdır. Ancak ileride bahsedileceği üzere bazı örneklerin önceleri düz toprak damla kaplı iken, onarımlar sonrasında kiremit çattyla kaplandığı görülmüştür. Yapıların çoğu tamamen düz tavan şeklinde olabildiği gibi ahşap tavan ortasında göbek, tekne biçimli çökertme, çıtalama göbek, kubbe, tonoz şeklinde taşıyıcı olmayan dekoratif elemanlar yer alır. Bazı örneklerde de ters tavan şeklinde yapılmış iç örtünün orta sahın üzeri kademeli tavan şeklinde düzenlendiği görülür.

\subsection{Düz Göbeksiz Tavanlı Câmiler}

Denizli ve çevresinde yer alan ahşap tavanlı câmilerden üst örtü bazen desteklerle taşınırken bazen de tamamen duvarlar tarafindan taşınmaktadır. Bu yapılarda yer alan düz tavanlar hiçbir dekoratif görünümü olmayan yapının durumuna göre enine veya boyuna uzunlamasına çıtalarla oluşturulmuştur.

$\mathrm{Bu}$ başlık altında gruplandırılan yapılar, dıştan kırma çatılı ve kiremitli olup, içerde sade ahşap tavanlıdırlar. Bir tek Kale Cevher Paşa Câminde tavan kirişlemesi üstten yapılmıştır. Denizli İnce Kara Câmiinde ise tavan göbeğinde ve köşelerde kalem işi süslemeler vardır (Resim 1a-1b). ${ }^{3}$

3. Vakıflar Genel Müdürlüğü Arşivinden alınan resimlerde belirli bir arşiv kodu bulunmadığından il kodu ve belgelendikleri yıla göre verilmişlerdir.
Tablo 2. Düz Göbeksiz Tavanlı Câmiler

\begin{tabular}{|c|c|c|}
\hline 1 & Babadağ & Kırcıtaş/Kırcataş Câmi \\
\hline 2 & Babadağ & Düvenönü Câmi \\
\hline 3 & Baklan & Çataloba Köyü Câmi \\
\hline 4 & Buldan. & Dört Eylül Câmi \\
\hline 5 & Buldan & Hacı Bekir Câmi \\
\hline 6 & Buldan. & Çarşı Câmi \\
\hline 7 & Buldan. & Şükür Câmi \\
\hline 8 & Buldan & Güroluk Câmi \\
\hline 9 & Buldan & Karşıyaka Câmi \\
\hline 10 & Bozkurt & Baklankuyucak Câmi $^{9}$ \\
\hline 11 & Çal & Kuyucak Köyü Câmi \\
\hline 12 & Denizli & Ulu Câmi \\
\hline 13 & Denizli & $\begin{array}{l}\text { Kuşpınar Hasan Fevzi Efendi } \\
\text { Câmi }\end{array}$ \\
\hline 14 & Denizli & Kiremitçi Câmi (Darıverenli) \\
\hline 15 & Denizli & İncekara Câmi \\
\hline 16 & Denizli & Saray Mahallesi Hacılar Câmi \\
\hline 17 & Denizli & Pelitlibağ Câmi \\
\hline 18 & Denizli & Akkonak Câmi \\
\hline 19 & Denizli & Öküzbattı Mescidi \\
\hline 20 & Denizli & Un (Odun) Pazarı Câmi \\
\hline 21 & Denizli & Saltak Câmi \\
\hline 22 & Denizli & Değirmenci Câmi \\
\hline 23 & Güney & Hacı Hüseyin Câmi \\
\hline 24 & Güney & Çarşı Câmi \\
\hline 25 & Güney & Çolacık Câmi \\
\hline 26 & Güney & Said Ağa Câmi \\
\hline 27 & Güney & Mestan Câmi \\
\hline 28 & Güney & $\begin{array}{l}\text { El-Hac Hasan ibn el-Hac } \\
\text { Halilzâde Câmi }\end{array}$ \\
\hline 29 & Güney & Hacı Habib Câmi \\
\hline 30 & Kale & Kale Pazaryeri Câmi \\
\hline 31 & Kale & Kale Cevher Paşa Câmi \\
\hline 32 & Tavas & Çayırlık Câmi \\
\hline 33 & Tavas & Paşalılar Câmi \\
\hline 34 & Tavas & Ulukent Câmi \\
\hline
\end{tabular}




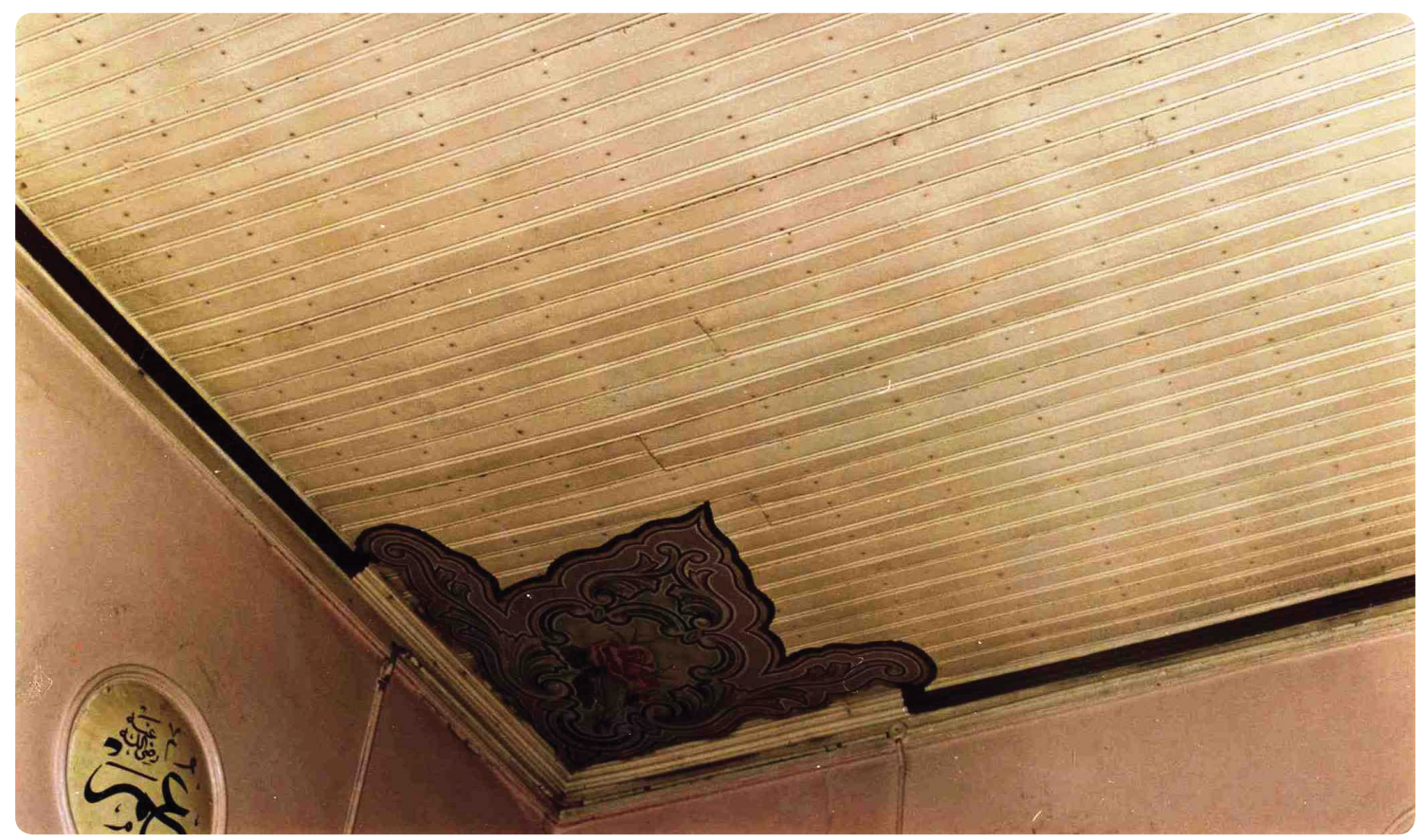

Resim 1.a-b incekara Câmi (VGMA, 20: 1990)

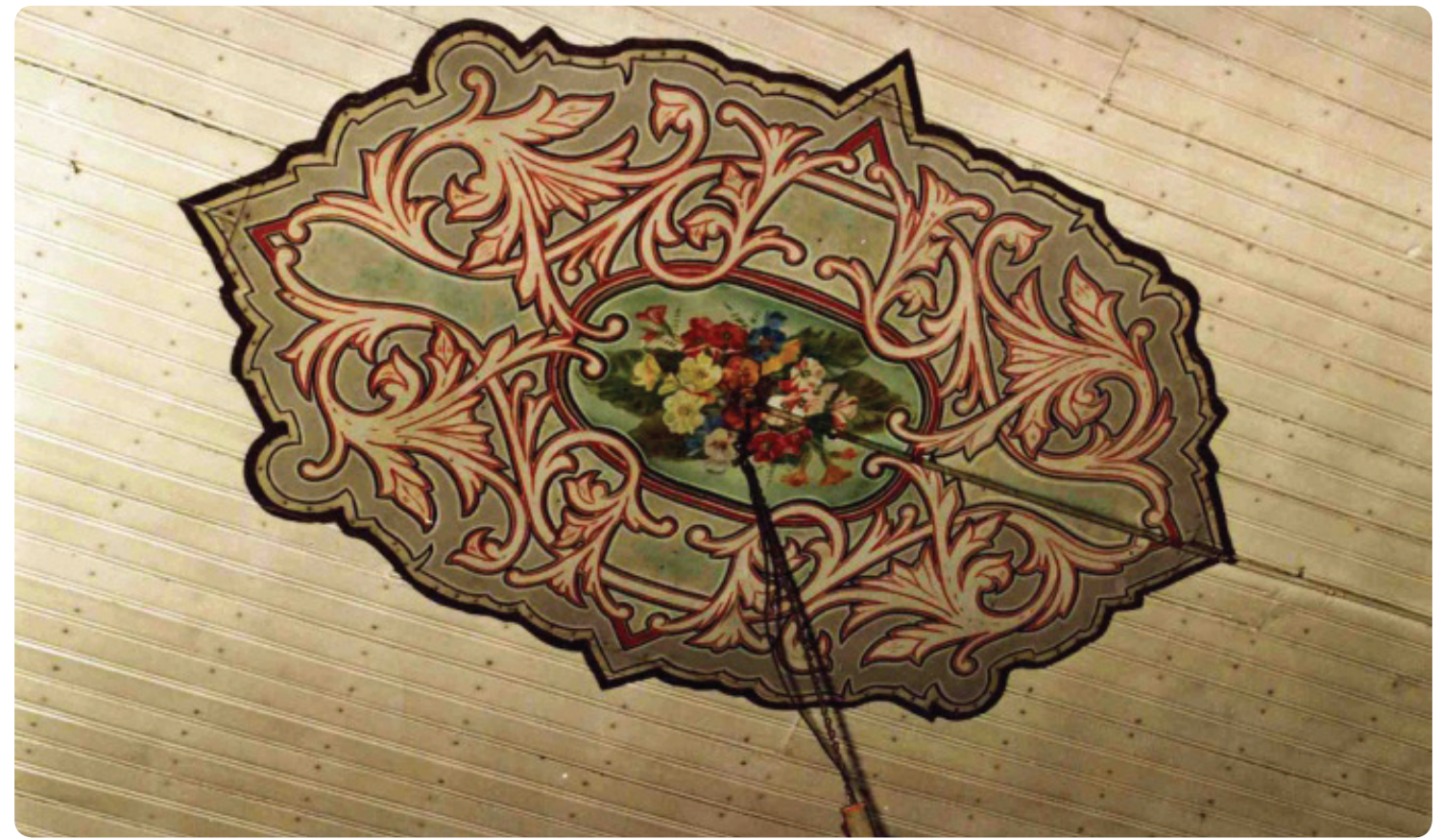

Resim 2.a-b Bozkurt Baklankuyucak Köyü Câmi 
Bozkurt Baklankuyucak Câmi (1814-15 M./ Kale Cevher Paşa Câmi(1819-20 M./H.1235) H.1230), ${ }^{4}$ (Resim 2-3). Çataloba Köyü Câmi düz tavan ahşap destekler tarafindan taşın(18.yy-sonu-19.yy başı) ve Çal Kuyucak Köyü, maktadır.
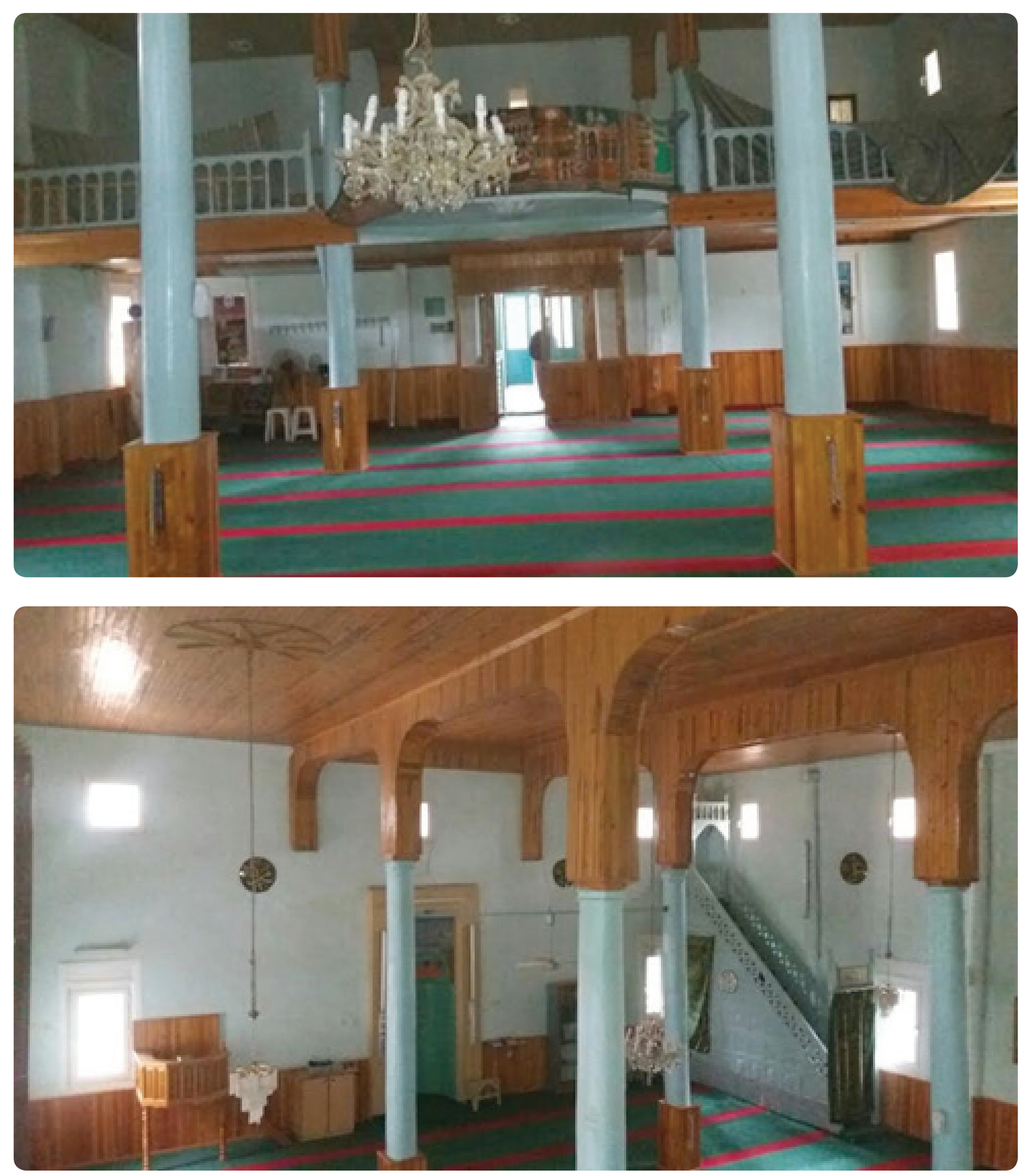

Resim 2 a-b Bozkurt Baklankuyucak Köyü Câmi Onarım Sonrası Harim Görünümü (Nisan 2017)

4. Kitabesine göre Çorbacı zade Seyyid Abdülkadir Ağa tarafindan yaptrıılmıştı. Onarım öncesinde çıtalı tavanla kaplı olduğu bilinen Yapı günümüzde yeniden inşa edilmiş olup eski halinden eser kalmamıştr. Elimizde eski haline ait siyah beyaz resimler olmasına rağmen resim kalitesi açısından yayında yer verilmemiştir (Çakmak, 1991: 72). 
Baklan Çataloba Köyü Câmi'nde (18.yy. sonu 19.yy. başı) destekler üzerine kuzey-güney yönünde yerleştirilen kirişler düz tavanı taşımakta ve kirişlerin üzeri doğu-bat yönünde çakılan düz çıtalarla örtülü iken (Çakmak 1999:res.250). Günümüzde yapı tamamen betonarme olarak inşa edilmiş olup eski görünümünden eser kalmamıştı (Resim 3). ${ }^{5}$

Kale Cevher Paşa Câmi'nde örtü düzeni önceki iki yapıya göre biraz farklıdır. Destekler üzerindeki kompozit başlıklar ve onun üzerinde de ikinci bir gövde izlenimi veren ağaçtan yapılmış yüzeyleri tahtalarla kaplanmış dikdörtgen prizma şeklinde ahşap destekler yer almaktadır. Bunların üzerinde ise profilli yastiklar oturur. Kuzey-güney doğrultusundan gelen kirişlerle doğu-bat yönünde uzanan kirişlerin kavuşma noktaları yastıklar üzerine denk getirilmiştir. Tavan ise düz tavan şeklinde olup, kirişlemesi üstten yapılmıştır. Dıştan kırma çat ve kiremit kaplıdır (Resim 4).

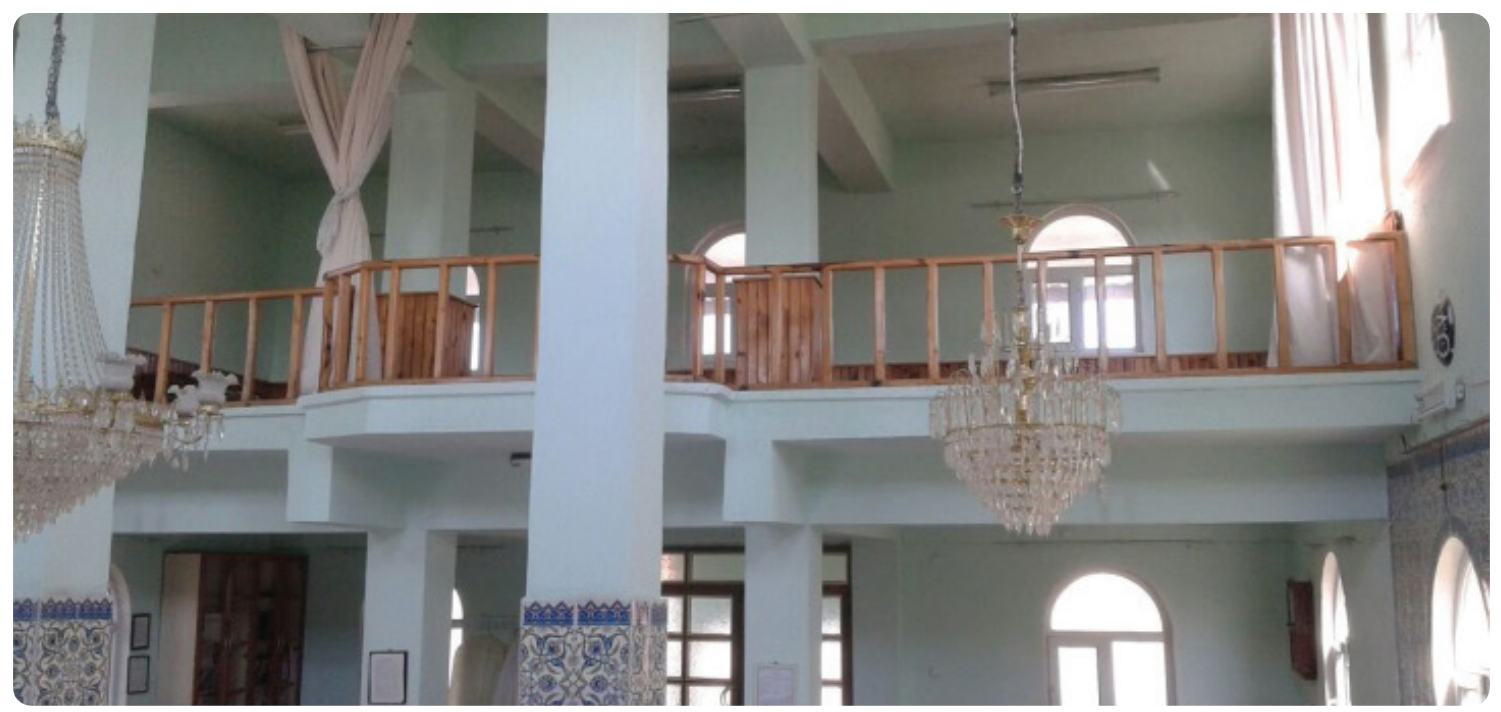

Resim 3 Baklan Çataloba Köyü Câmi Kadınlar Mahfili (26 Mart 2017)

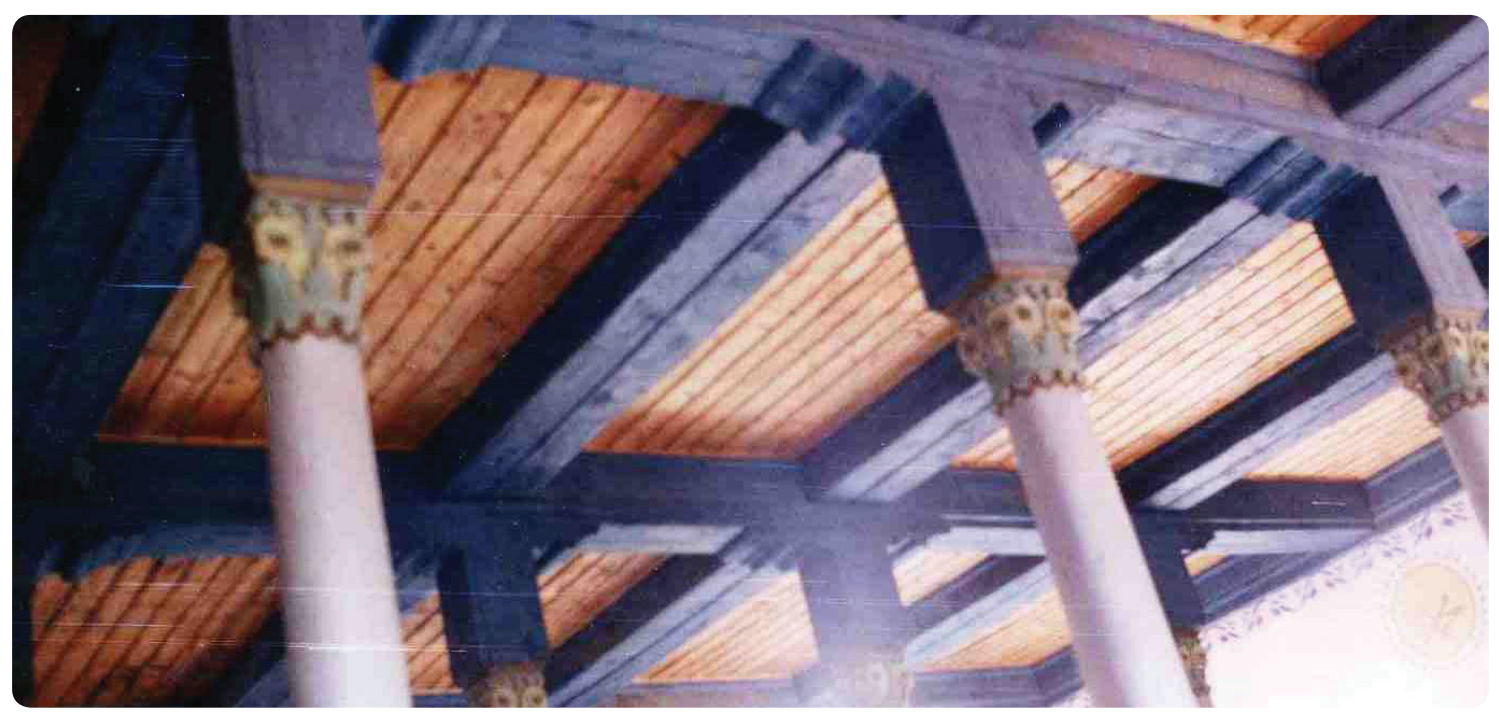

Resim 4. Kale Cevher Paşa Câmi Ahşap Kirişler ve Profilli Yastiklar (VGMA,20: 2006).

5. Köylülerden alınan bilgiye göre cami 2007 'de yeniden yapılmıştr. 


\subsection{Düz Çökertme Tekne Göbekli Tavanlı Câmiler}

Düz ahşap tavanlı câmilerin tavanlarında rastlanan diğer bir uygulama ise, çökertme göbekli tavanlardır. Tavanların tam ortasında, genellikle kare şeklinde sembolik, tavan yüzeyinden daha derince bir bölüm oluşturularak içi basit kalem işi süslemelerle bezenmiştir.

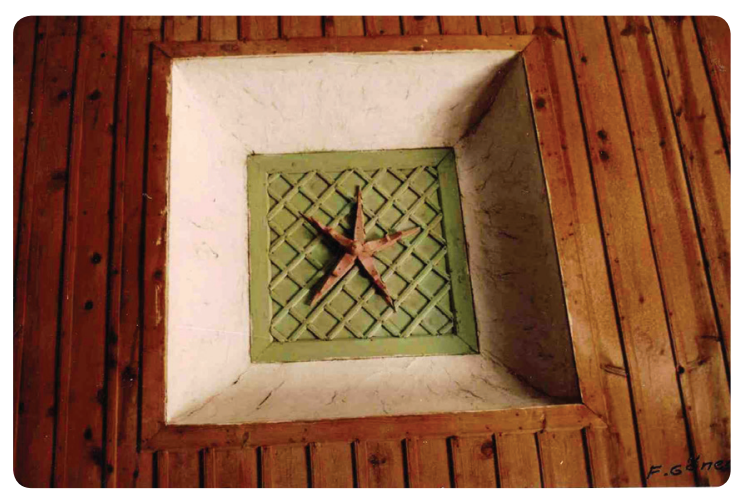

Resim 5. Tavas Avdan Baba Câmi (VGMA, 20:2010)

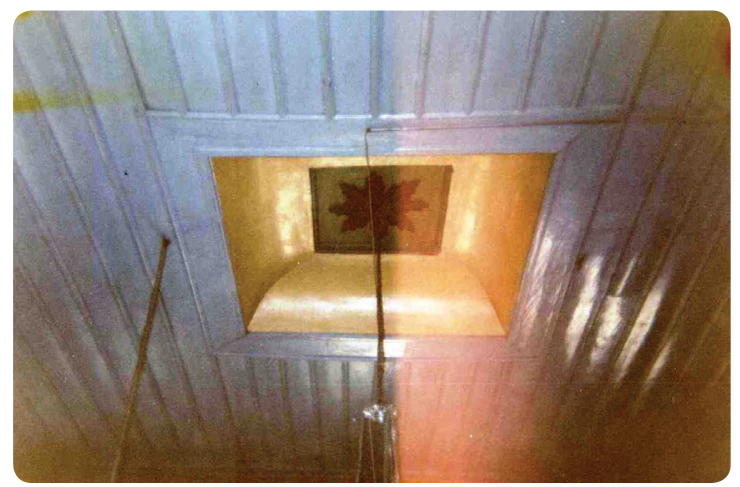

Resim 6. Sarayköy Hükümetönü Câmi(VGMA,20:2004)

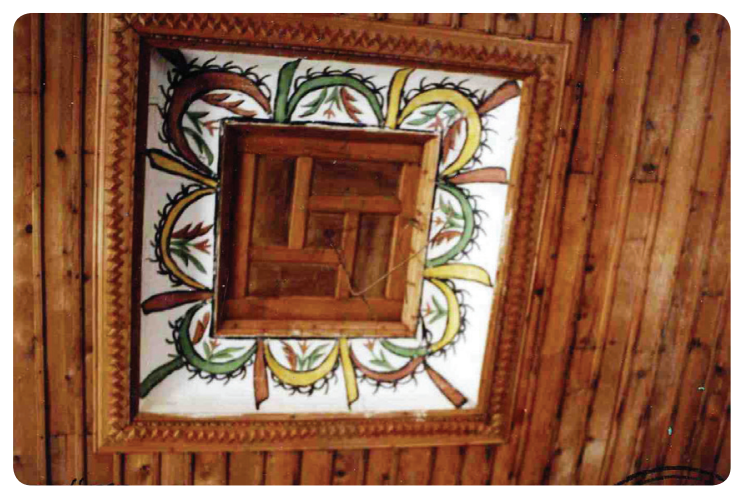

Resim 7. Tavas Aydoğdu Köyü Câmi( VGMA,24:2004)
1909 M./H.1327 tarihli Tavas Avdanbaba Cami (Resim 5), 1906 tarihli Sarayköy Hükümetönü Câmi (Resim 6), 19.yy.2.yarıya ait Tavas Aydoğdu Köyü Câmi (Resim 7), 1910 tarihli Acıpayam Ovayurt/Taraş Köyü Câmi (Resim 8), 19.yy. sonu-20.yy başına ait Tavas Mestanağa Câmi (Resim 9), 1733 M./H.1146 tarihli Tavas Ali Ağa Câmi (Resim 10a-b),

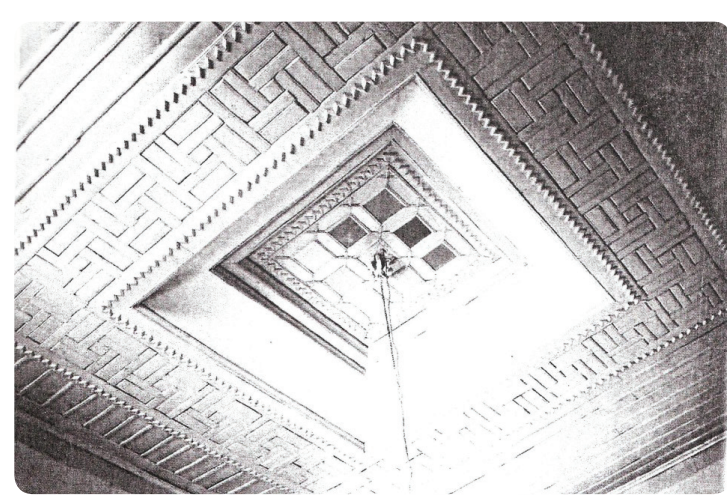

Resim 8. Acıpayam Ovayurt Taraş Köyü Câmi (Ince, 2003:446)

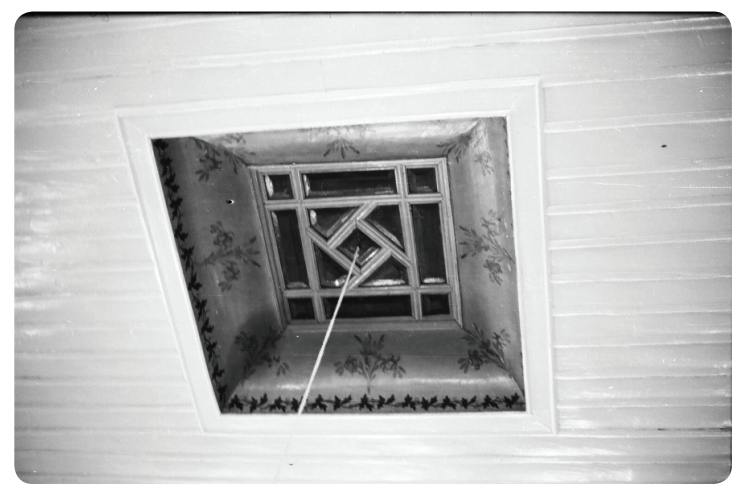

Resim 9. Tavas Mestanağa Câmi (VGMA, 20 :1998)

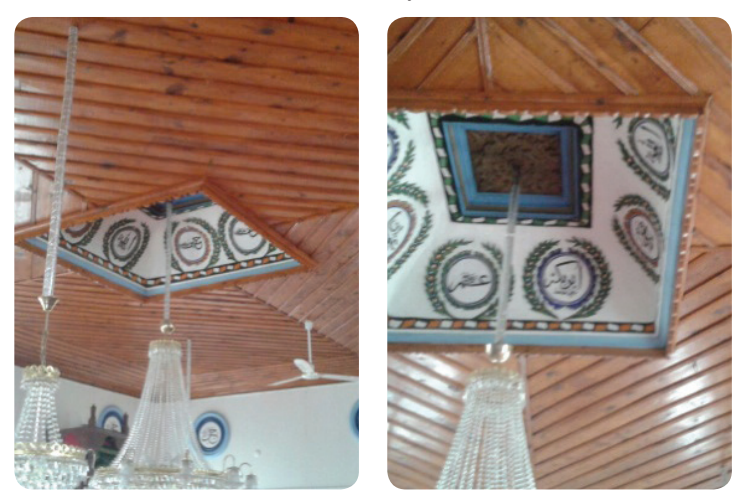

Resim 10a-b. Tavas Ali Ağa Câmi (6 Nisan 2017) 
1859 M./H.1276 tarihli Serinhisar Ağalar (Hacl Hamza) Câmi, 1860 M./H.1277 tarihli Tavas Çarşı Câmi, 1871 M./H.1288 tarihli Tavas Dedeli Câmi, Kızılcabölük Hanönü Câmi, 19011902 tarihli Babadağ Hamidiye, 19.yy.2.yarısına ait Kavaklı Câmi, Tavas Yukarı Câmi (İnce, 2007:169) Acıpayam Apa Köyü Câmi (Pektaş, 2003b:430) gibi örneklerde tavan ortasında kare göbek şeklinde çökertme göbek uygulamalar mevcuttur.

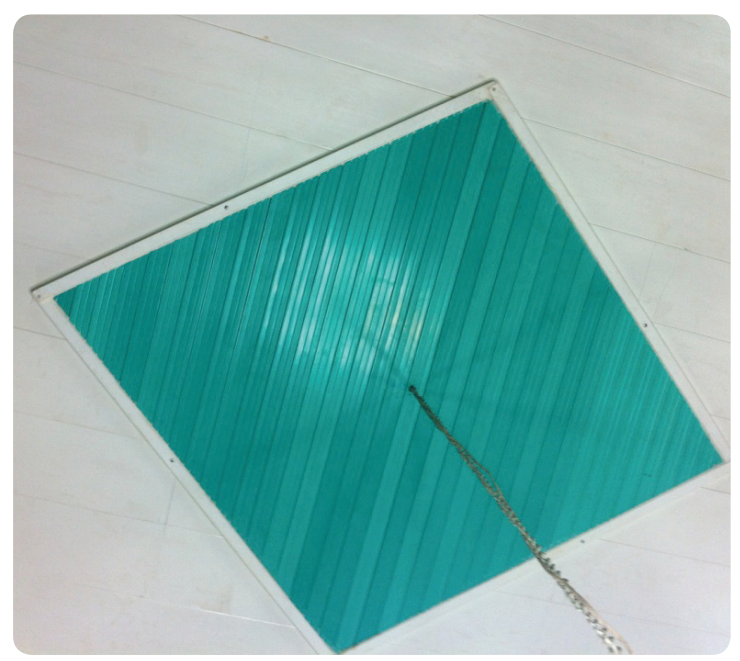

Resim 11. Güney Dere Câmi (Çevrimli, 2012)

\subsection{Düz Çıtalama Göbekli Tavanlı Câmiler}

Güney Dere Câmi'nde (1802 M./H.1227) ise basit çıtalı baklava şeklinde bir tavan göbeğine yer almaktadır (Resim 11). Babadağ Yukarı Kuzere Ahmet Paşa Câmi (1870) (Resim 12) ile Sarayköy Çarşı Câmi'nde (18.yy) düz tavanın küçük kareler şeklinde çıta kârî olarak yapıldığı görülür (Resim 13). Ortada kare şeklinde yine çıtalarla oluşturulmuş yüzeyden hafif çıkıntılı birer göbek mevcuttur. Çökertme göbekli tavanlar başlığı altında verilen Tavas Ali Ağa Câmi (1733 M./H.1146) ile kubbeli göbekli Akköy Yukarı Câmi'inde (18 yy. sonu 19. yy. başı) ta-

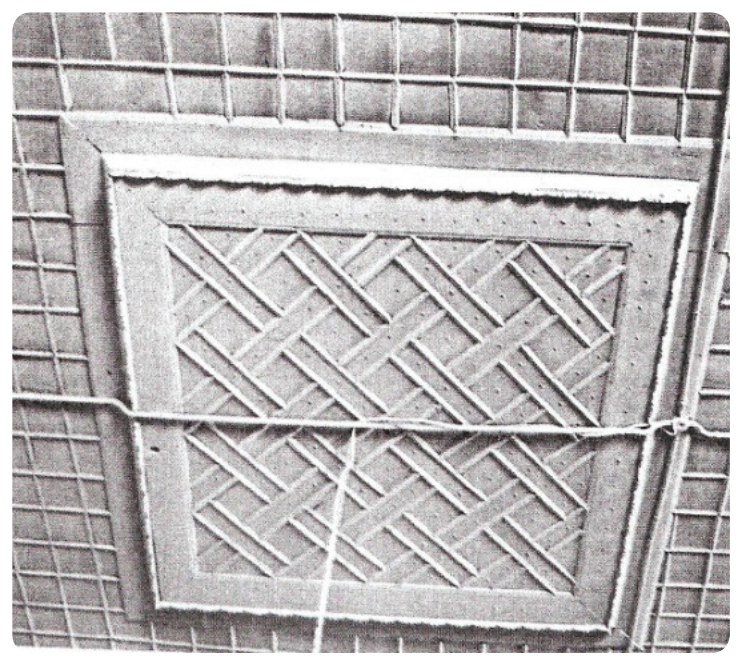

Resim 12. Yukarıkuzere Ahmet Paşa Câmi Tavanı (Ince, 1999:496)

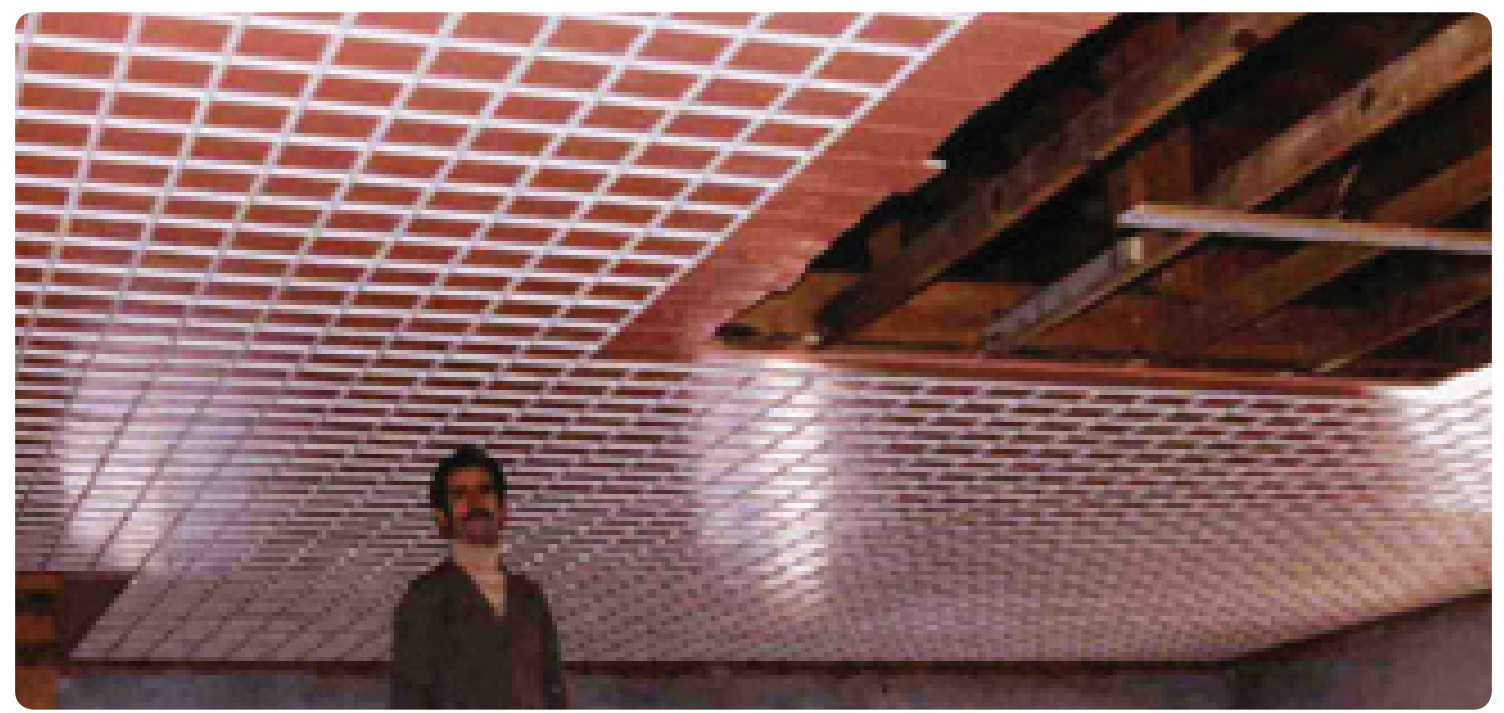

Resim 13. Sarayköy Çarşı Câmi Tavan (VGMA, 20:2004)

Vakıflar Dergisi 47 - Haziran 2017

$$
\text { or } 178
$$


vanlar çıtalı tavan şeklindedir. Ele alınan yapılardan Çivril Gümüşsu Dere Câmi'nde (19.yy) ise çıtalama tavan ortasında sekizgen bir form oluşturulmuş, sekizgenin her bir kenarı yere dikey çıtalarla çevrelenmiş ve kenarlardan duvara dik uzanan ve kenarlara doğru genişleyerek uzanan çıtalardan oluşmuştur (Resim 14). ${ }^{6}$

\subsection{Düz -Kubbeli Tavanlı Câmiler}

Düz ahşap tavanlarda görülen taşıyıcı fonksiyonu olmayan sembolik diğer bir öge de tavanlarda yapılan kubbelerdir. Babadağ Aşağı Tepeardı Câmi (Ince, 1999: 498) (1906M./H.1323) (Resim15), Tavas Ebubekir Câmi (1810-1820
M./H.1225) (Resim 16), Acıpayam Yassıhöyük Eski Câmi (1942 tamir) (Resim 17), Yatağan Teke Müsellim Câmi'nde (1811 M./H.1266) (Resim 18a-b) ahşap kubbeler mevcuttur. Bunlardan başka Denizli merkezde Hacı Kaplan (Resim 197) ve Hatipoğlu Câmileri ile Çardak Söğüt Köyü Câmileri, Serinhisar Hacı Hamza (Ağalar) Câmi (1859 M./H.1276), Çivril İğdir Köyü Câmi, Çardak Gemiş Köyü Câmi ve Sarayköy Hisarköy, Sarayköy Hasköy Câmilerinde tavan ortasında göbeklerin varlığı bilinmektedir (İnce, 2007: 145). Yine Akköy Yukarı Câminde de (18.sonu19.yy.başı) düz ahşap tavanda kubbe mevcuttur (İnce, 2001: 65-79).

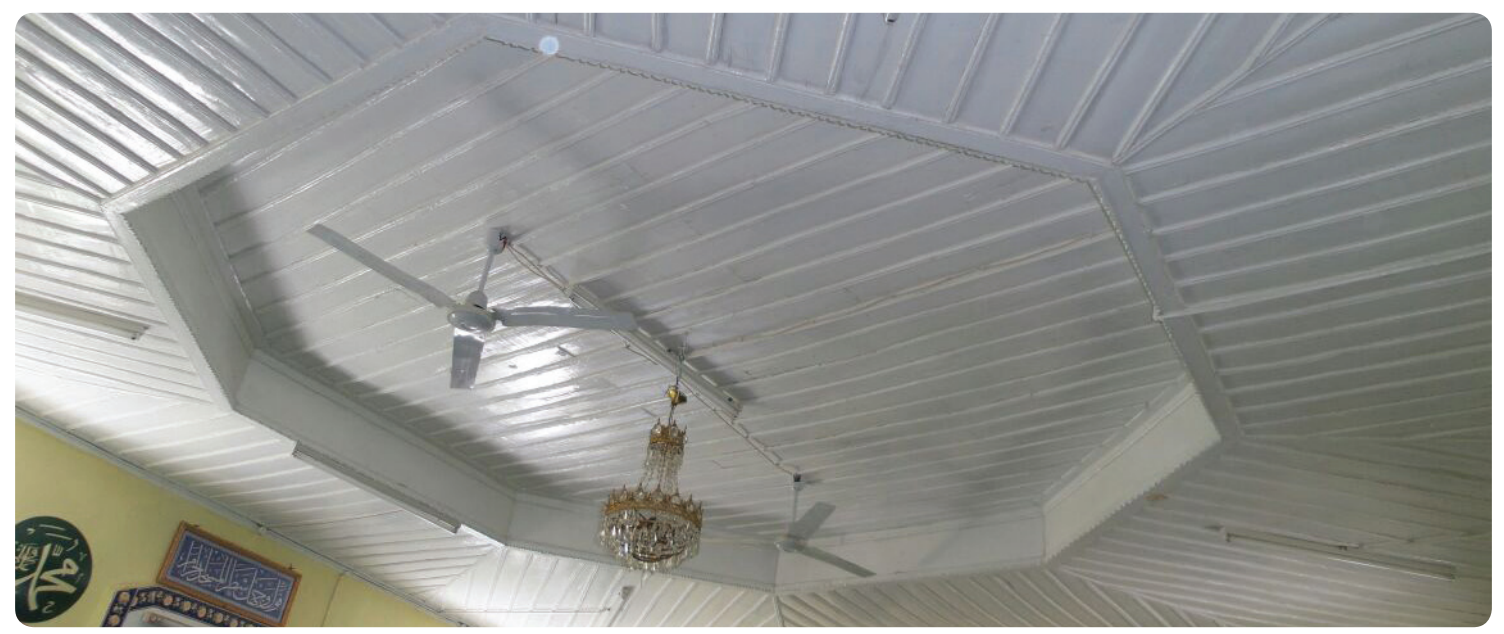

Resim 14. Gümüşsu Dere Câmi ( 21 Nisan 2017)

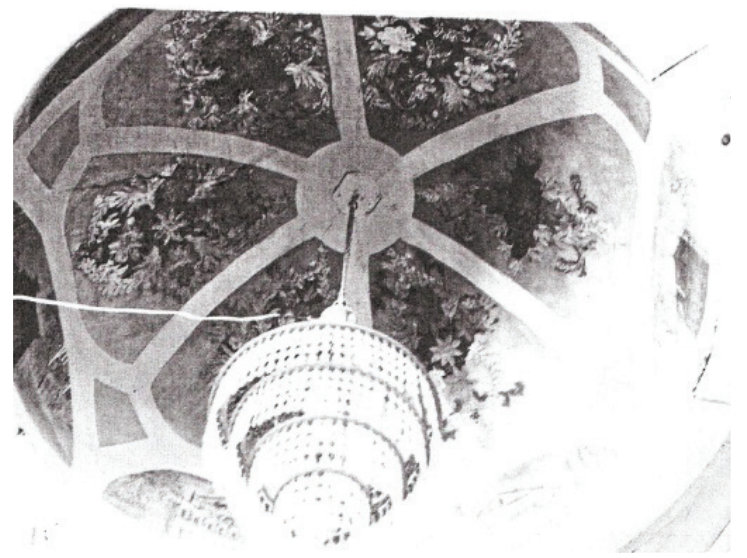

Resim 15. Babadağ Aşağı Tepeardı Câmi Kubbeli Tavan (Ince, 2003: 498)

6 Cami kapalı olduğu için resim çekilemediğinden, kendi özel fotoğraf arşivinden bu resmi sağlayan Sayın Süleyman Tüzün'e teşekkür ederim.

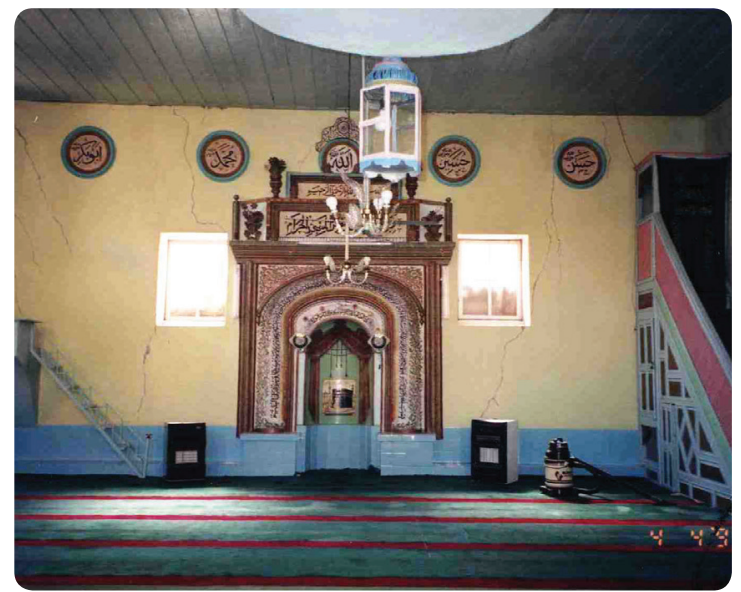

Resim 16. Tavas Ebubekir Câmi (VGMA, 20: 2003)

7 Aydın Vakıflar Bölge Müdürlüğü (AVBM) olarak kısaltıımıştır. 


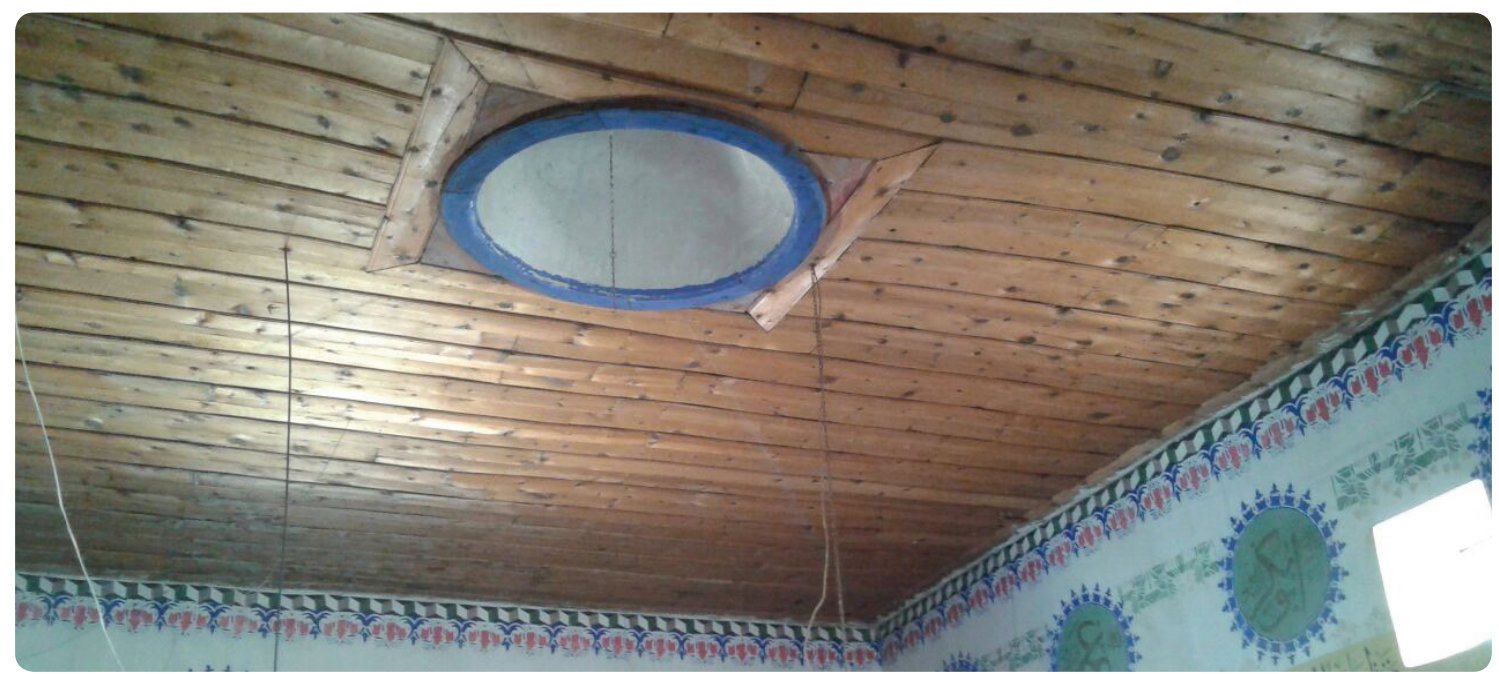

Resim 17. Acıpayam Yassıhöyük Eski Câmi (28 Mart 2017)

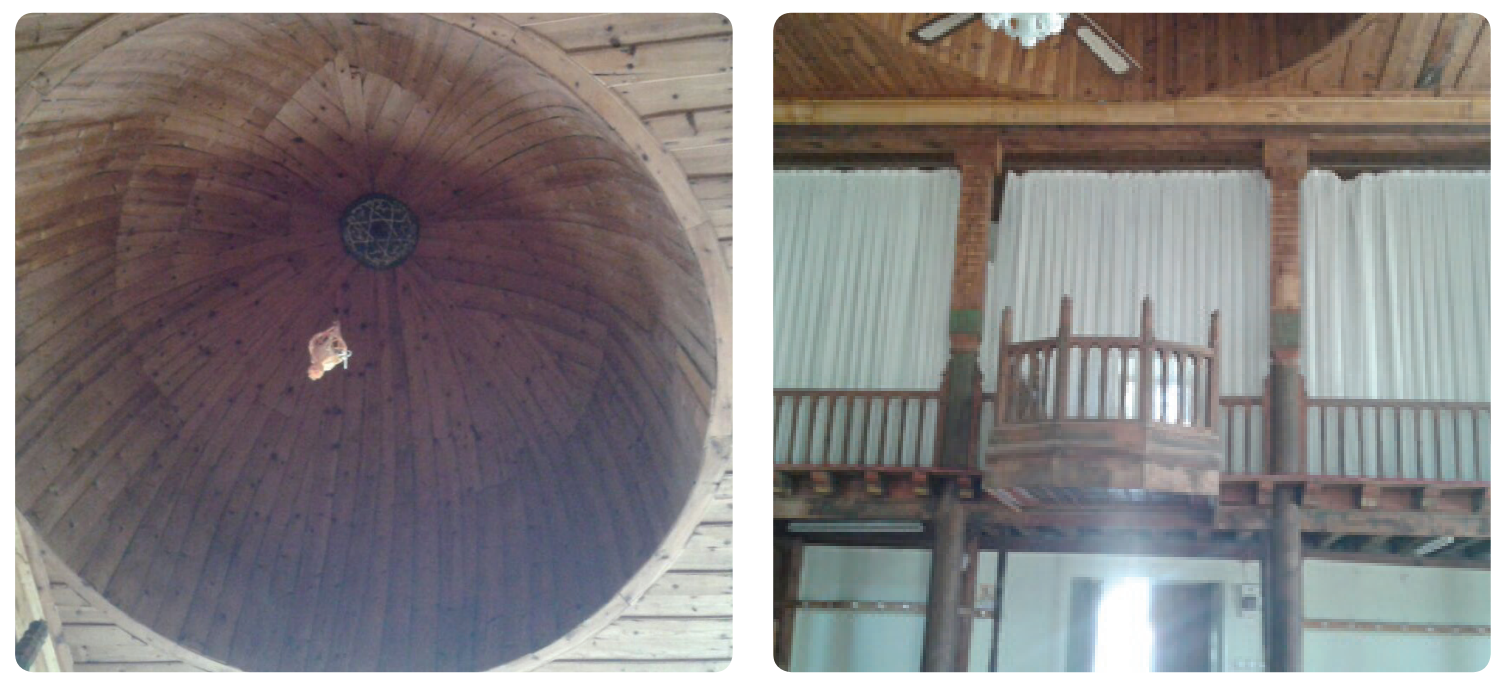

Resim 18. a-b Yatağan Teke Müsellim Câmi (28 Mart 2017)

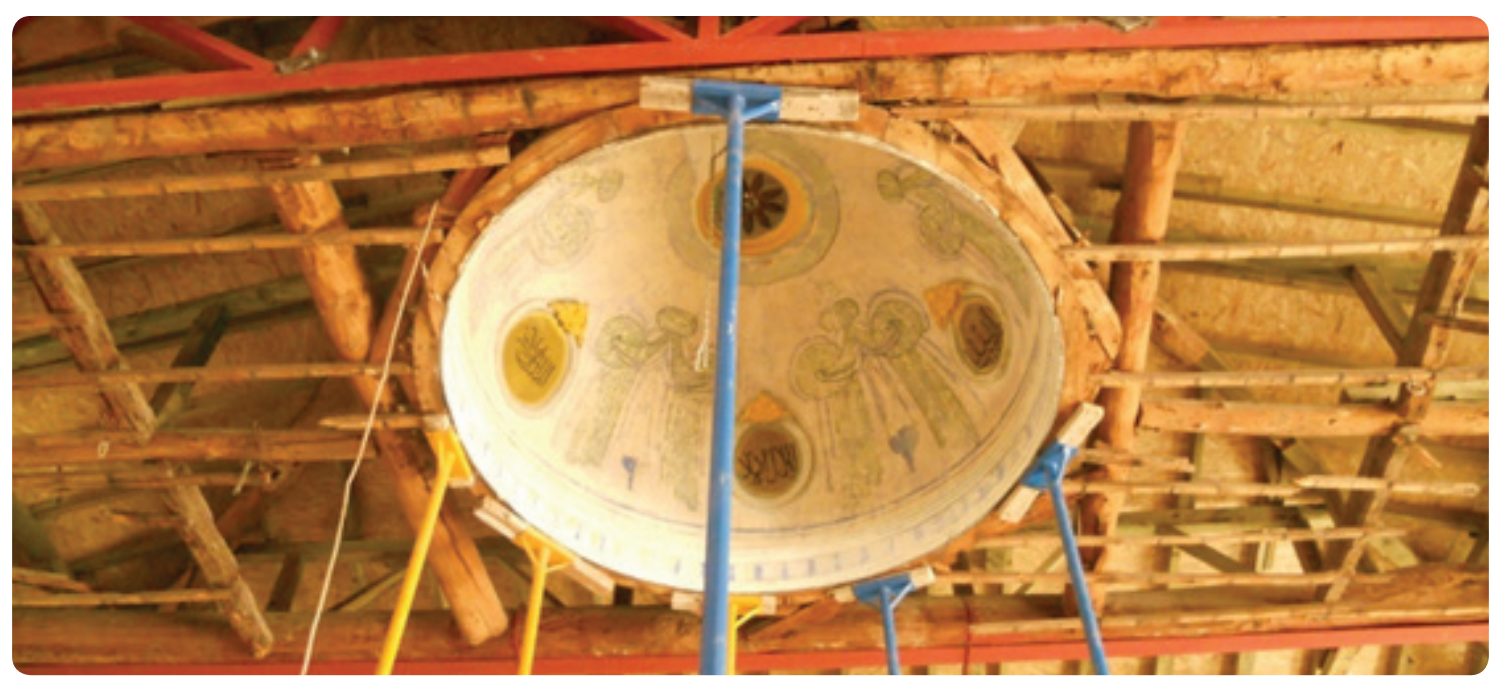

Resim 19.Denizli Hacı Kaplan Câmi (AVBM -2016)

Vakıflar Dergisi 47 - Haziran 2017

$$
\text { Ge. } 180 \text { e }
$$




\subsection{Düz- Tonozlu Tavanlı Câmiler}

Düz ahşap tavanlı 19.yüzyıl ortalarına tarihlenen Çal Merkez Çarşı Câmi'nde düz ahşap tavanla örtülü bölümünde ortada bir, köşelerinde dört olmak üzere toplam beş çapraz tonoz yerleştirilmiştir ve üzeri dıştan kırma çatılı ve kiremitle örtülmüştür (Resim $\left.20^{8}\right)$. Tonozların üzerleri bağdadi sıva ile kaplıdır. Çapraz tonozlar kare tabana sahiptir ve birbirleriyle birleşim noktalarında kare şeklinde dört ana taşıyıcı ahşap kolonla desteklenmiştir. ${ }^{9}$

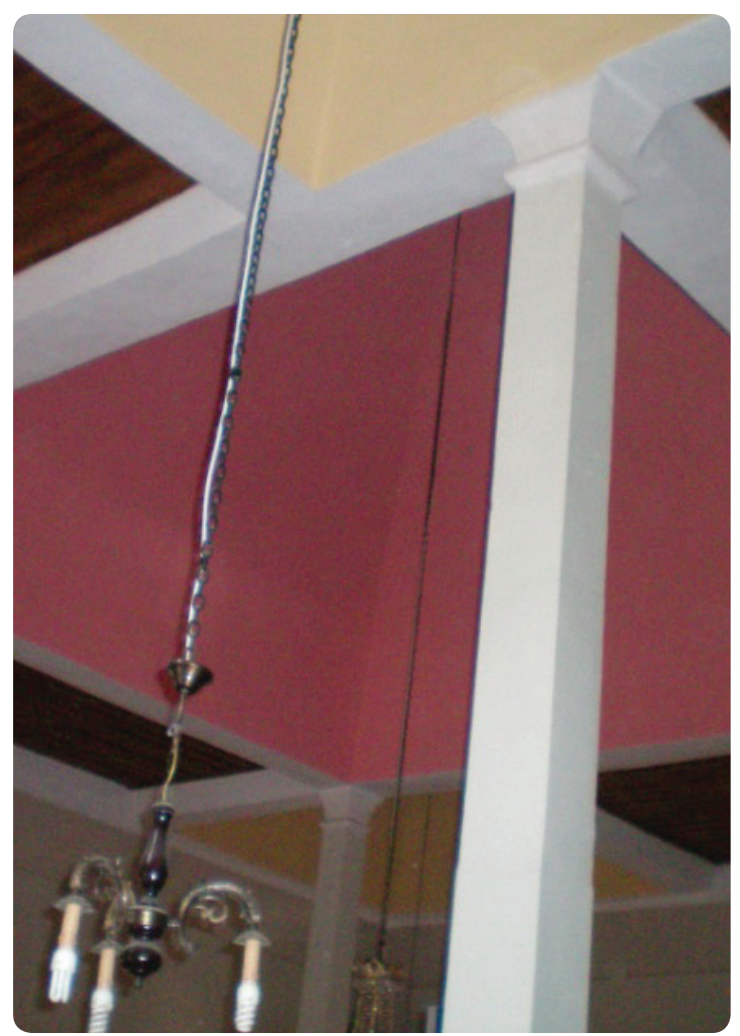

Resim 20. Çal Çarşı Câmi

\subsection{Düz- Kademeli Tavanlı Câmiler}

Düz ahşap tavanlı Câmilerden aşağıda isimleri verilen sekiz yapıda orta sahnın üzeri kademeli tavan şeklinde düzenlenmiştir. Bekilli Çoğaşı Köyü Câmi (1743 M./H. 1156), Baklan Boğaziçi Çalkebir Köyü Eski Câmi'nde (1774-75 M. /

8 Fotoğrafları çekip gönderen Çarşı Cami Müezzini İbrahim Bozkurt ile müftülük görevlisi Hüsnü Üçkuyulu'ya teşekkür ederim (30.11.2012).

9 VGMA 2007 Yılı Çal Merkez Çarşı Cami hakkında teknik rapor.
H.1186), ${ }^{10}$ Acıpayam Çivril Savran Köyü Serbanşah Câmi (18. Yüzyılın üçüncü çeyreği), Acıpayam Yazır Çarşı Câmi (1802M./H.1217), Çivril Bayat Köyü Câmi (18.yy.sonu 19.yy başı) Çal Kocaköy Şalvan Câmi'nde (18.yy-sonu-19. yy başı), Güney Belenardıç Köyü Câmi (1884 M./R.1300), Baklan Tekke Câminde (18.yy-sonu-19.yy başı) tavan şeklinde olup orta sahınların üzeri kademeli ters tavan şeklindedir. Üst örtü dıştan kırma kiremit çatılıdır.

Bekilli Çoğaşlı Köyü Câmi'nde (1743 M./H. 1156), Orta sahın ana kirişlerde yer alan profilli konsollarla yükseltilmiş olup tavan, kademeli tavan şeklinde yapılmıştı (Çakmak, 1991: 96). Tavanı taşıyan sekizgen desteklerin üzerinde profilli yastiklar ve onun üzerinde de kuzey-güney yönlü kirişler vardır. Yan sahınlar bir yandan bu kirişlere diğer yandan duvarlara oturan $25 \mathrm{~cm}$. aralıklarla döşenmiş doğu- bat yönlü kirişlerle örtülü olduğu anlaşılmaktadır (Çakmak, 1997: res:238).

Baklan Boğaziçi Çalkebir Köyü Eski Câmi'sinde (1774-75 M./H.1186) destekler, kuzey-güney

10 Baklan Eski Cami ve Çal'da bulunan diğer iki cami ile ilgili Kaymak Mustafa Paşa'nın 1728 M./H. 1140 Cemâziye'l-ûlâ tarihli vakfiyesinde şu bilgilere ulaşılmaktadır: “...Kayıpazarı'nda hayatında müceddeden bina idüb ta'yin-i cihât eylediği Câmi'-i şerîfte hatip olanlara yevmî beş akça ve vâ'iz olanlara yevmî beş akça ve imâm olanlara yevmî beş akça ve kâtib olanlara yevmî beş akça ve câbi' olanlara yevmî beş akça ve müezzin olanlara yevmî üç akça ve kayyım olanlara yevmî iki akça ve ferraş olanlara yevmî iki akça ve siraci olanlara yevmî bir akça ve bevvâb olanlara yevmî bir akça vazife verile ve yine Pazar-ı mezkûrda vâki' Atik Câmi'-i şerîfin imâm ve müezzin ve kayyımından her birine yevmî birer akça vazîfe verile ve Baklan Kazası'nda Çiftlik-i Dayılar nâm mahalde vâki' câmi'-i şerîfin imâmına yevmî iki akça ve müezzinine yevmî bir akça vazîfe verile ve balâda zikrolunduğu üzere sâlifü'z-zikr Kayıpazarı'nda vâki' müsakkafât ve mezâri'nin gallâtnı tahsîl ve câmi'-i mezbûrın iktizâ eden şem'-i ruğan ve zeyt vesâir masârifini rü’yet ve vezâif-i mezkûreyi erbâb-ı cihâta teslîm içün merhûm-ı mezbûrun evkâf-ı mütevellisi tarafindan bir kaymakam-ı mütevelli nasb ve ta'yin olunub beher yevm on akça vazife verile ve kaymakam-ı mezburun Camii mezkur kâtibi kalemiyle asitane-i saadette asıl mütevelli ma'rifetiyle beher sene muhâsebesi görülüb harcırah olmak üzere beher sene bin iki yüz akça kaymakam-ı mezbûre ve altiyüz akçe kâtib-i merkûma üç yüz akça câbiye verildikten sonra ol cânibde olan irâd-ı vakıfdan vezâif-i mezkûre ile câmi'-i mezbûrun sâir masârıfindan fazla kalırsa asıl mütevelliye teslîm oluna..."(VGMA, 735: 119/49). 
yönünde uzanan ana kirişleri taşımaktadır (Resim 20a-b). Kuzey duvarına en yakın iki destekle ana kiriş arasında profilli yastıklar vardır. Yan sahınların bir tarafi duvarlara, diğer tarafi ana kirişlere oturur (Çakmak,1997: 30). Orta sahın

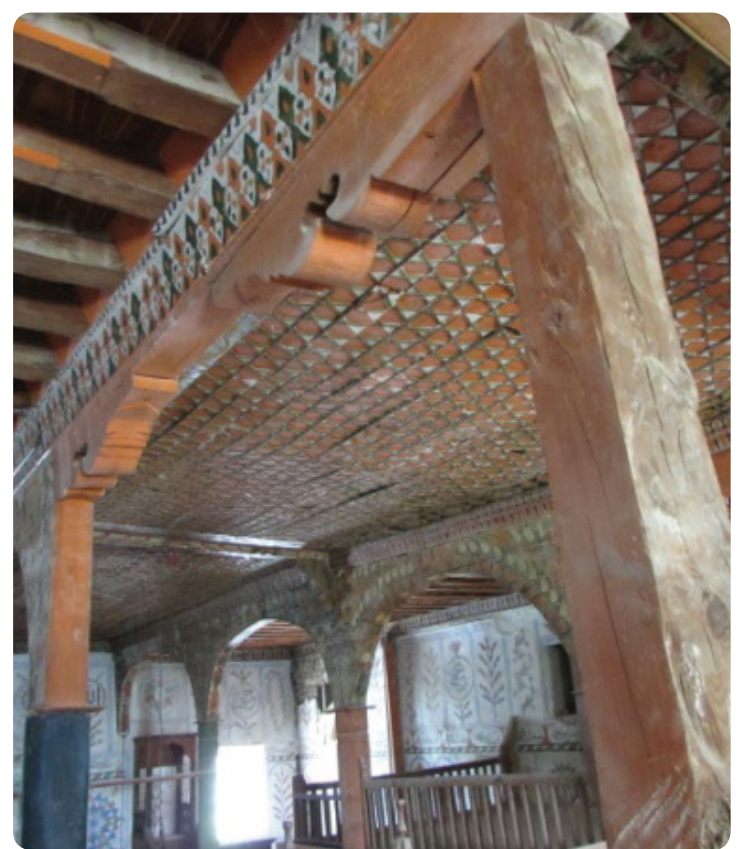

yanlardan yüksek tutularak tavan doğu-bat yönünde bir kirişle ikiye ayrılmıştır. Sahınların üstü düz ahşap kirişleme şeklinde yapılmış olup, orta bölüm kademeli tavan şeklinde düzenlenmiştir (Resim 21a-b).

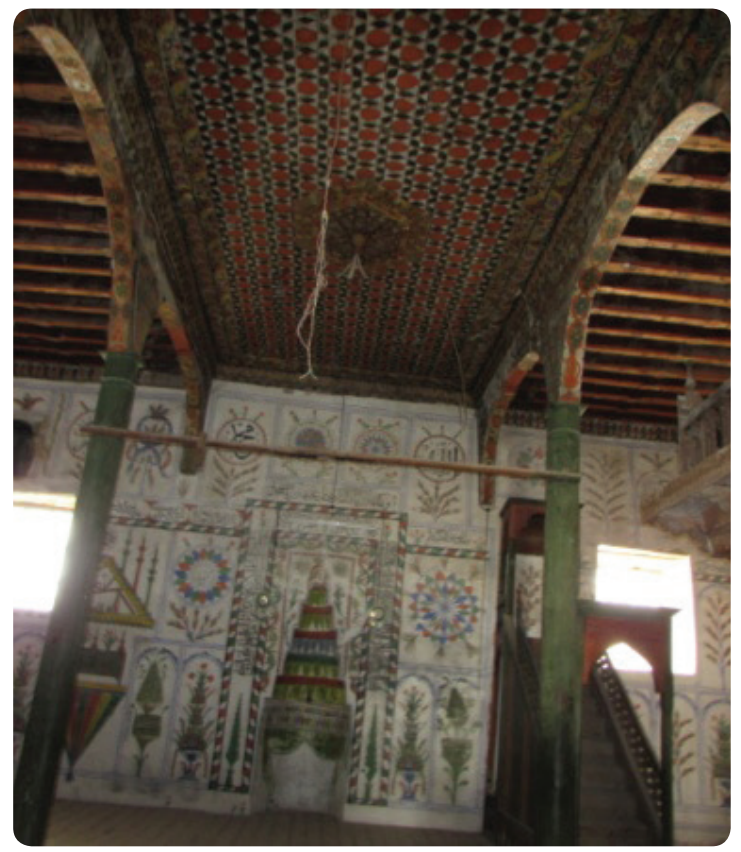

Resim 21.a-b Baklan Boğaziçi Çalkebir Köyü Eski Câmi (AVBM -2017)
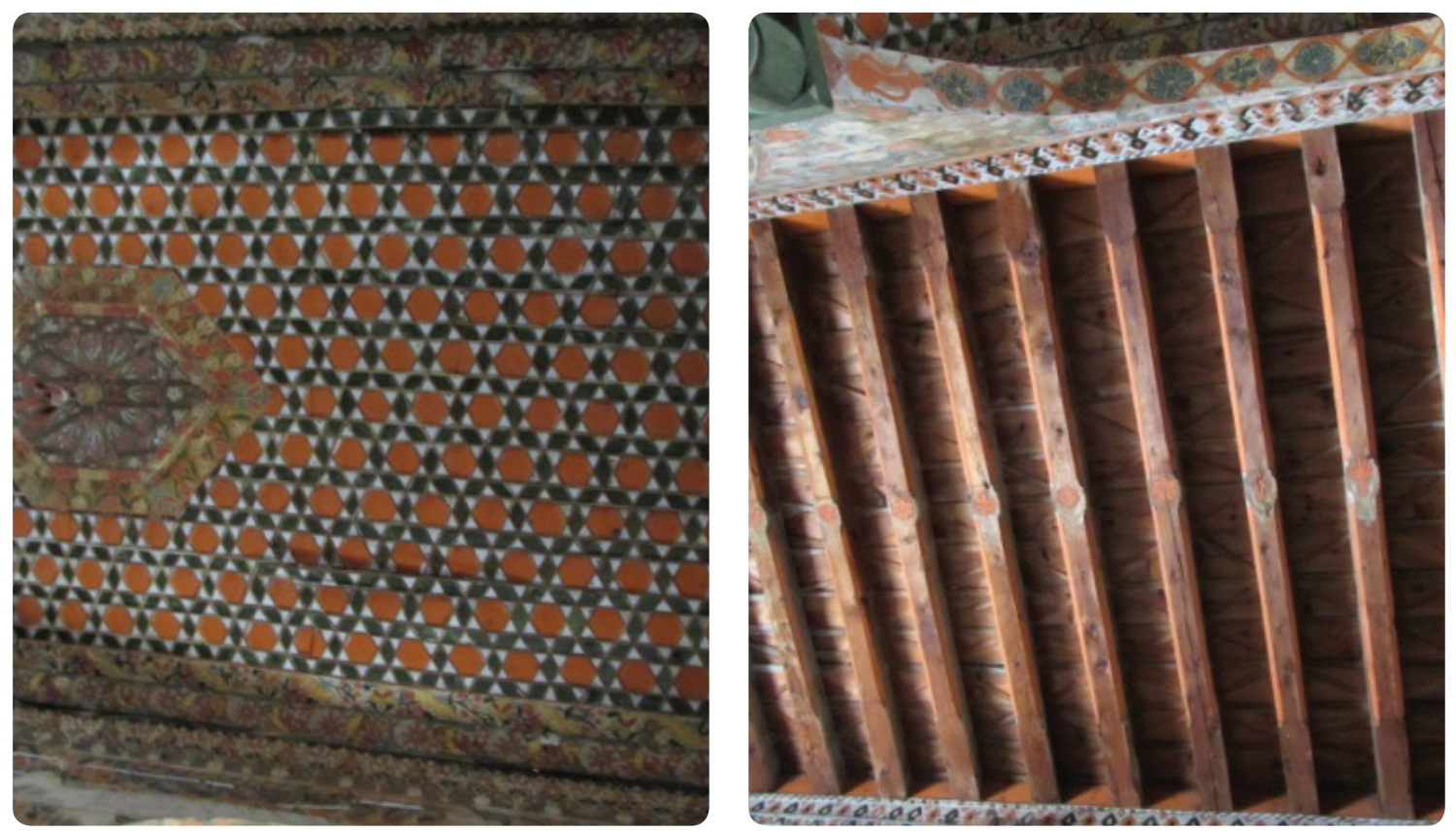

Resim 21. c-d Baklan Boğaziçi Çalkebir Köyü Eski Câmi (AVBM -2017) 
Çivril Savranşah Köyü Serbanşah Câmi (18. Yüzyılın üçüncü çeyreği), orta sahın yan sahınlardan yüksek tutularak kademeli tavan şeklinde düzenlenmiştir. Sahınların üzeri ise doğu-batı yönünde 0,15-0,20 m. aralıklarla yerleştirilen kirişlerle örtülerek alttan düz tahtalarla kapatılmıştır. Kirişlerin mekâna bakan yüzleri ise çıtalarla çaprazlamasına baklava şeklinde motiflerle süslenmiştir. Orta sahında tavan ortasında altıgen bir göbek yer almaktadır (Resim 22).

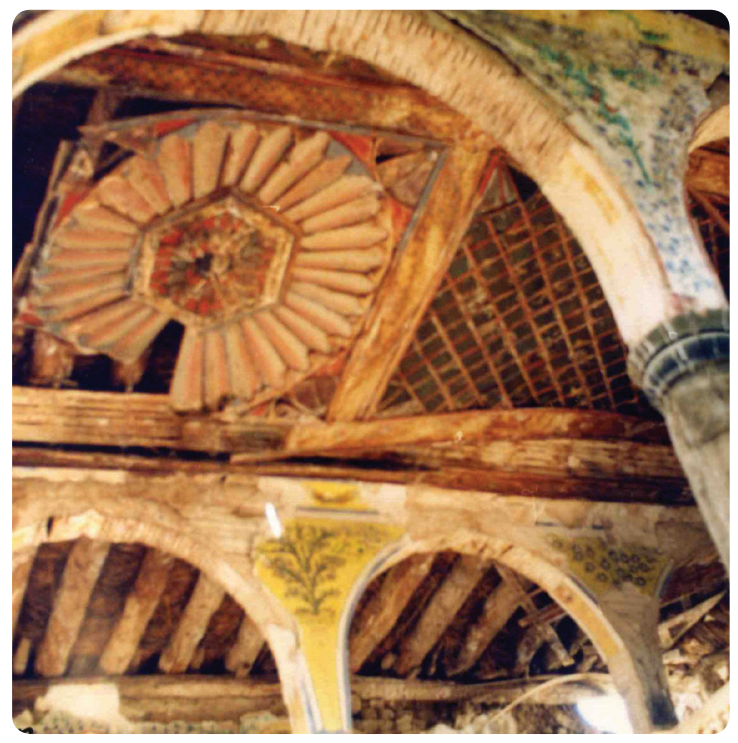

Resim 22. Serbanşah Câmi (VGMA, 20: 2001).

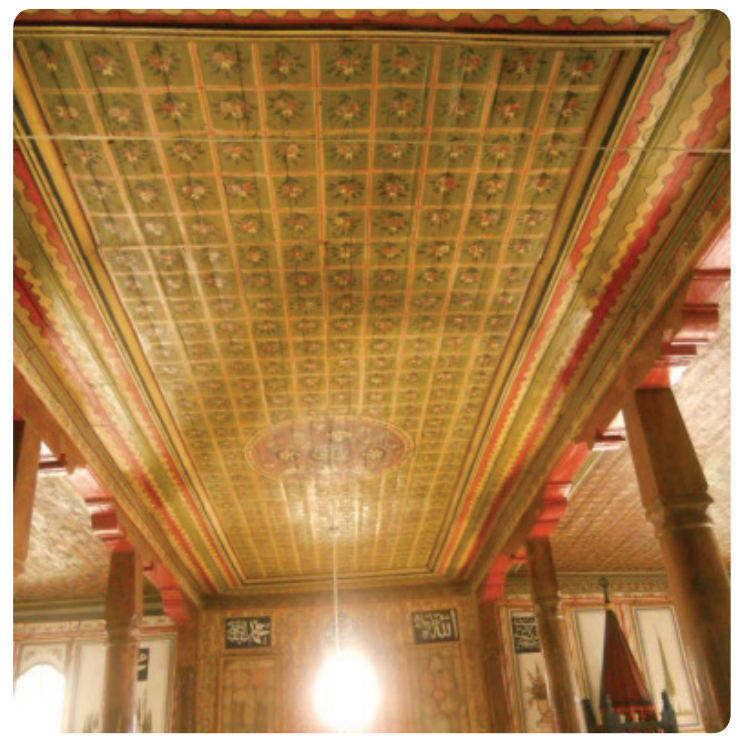

Resim 24. a-b Yazır Kasabası Câmi (AVBM: 4 Nisan 2017).
Acıpayam Yazır Köyü Çarşı Câminde (1802 M./H.1217) ise destekler üzerine kuzey-güney yönünde uzanan kirişler yerleştirilmiştir. Harim tavanının kuzeyi bir kirişle kare şeklinde üç bölüme ayrılmıştır (Resim 23). Orta sahın kenarlarda yükseltilerek kademeli tavan şeklinde düzenlenmiştir (Resim 24a-b).

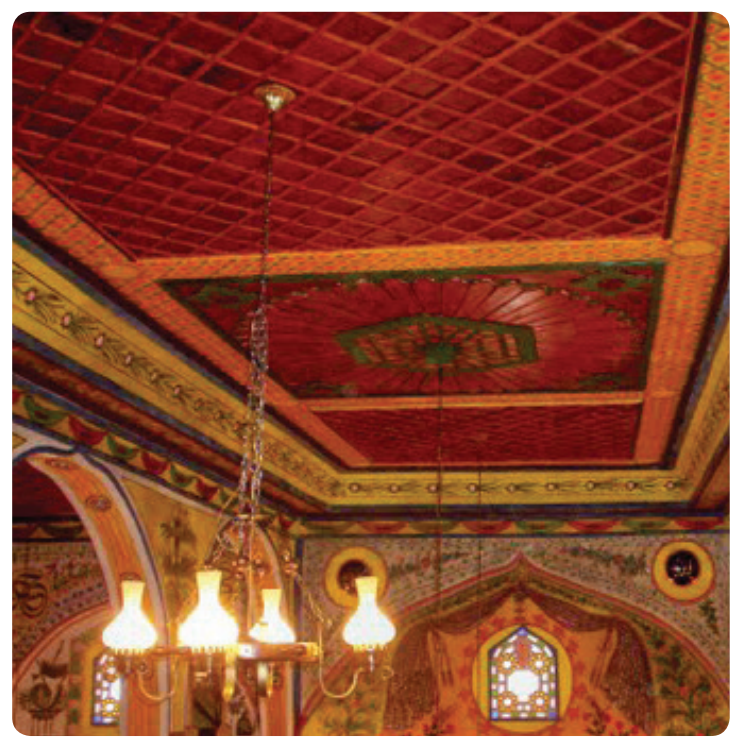

Resim 23. Serbanşah Câmi (AVBM : 2011).

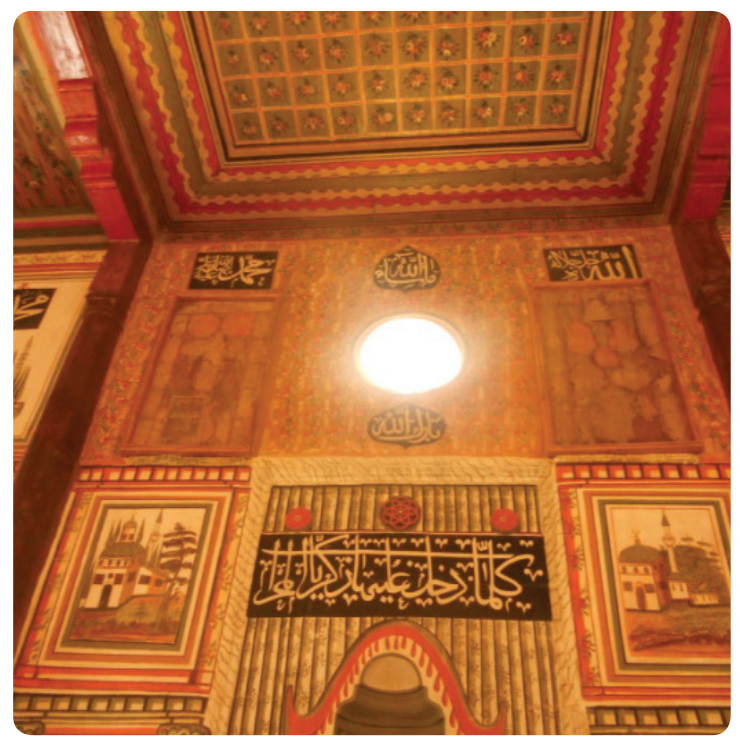


Çivril Bayat Köyü Câminde (1872), kuzey-güney yönünde uzanan ana kirişlerin desteklere oturduğu yerde profilli birer yastık bulunmaktadır. Profiller ortada tam, uç kısımlarda yarım haldedir. Ana kirişler üzerine doğu- bat yönde atılan kirişlerle üst örtünün yükü duvarlardan desteklere aktarılmıştır (Resim $25^{11}$ ). Orta sahın yanlar dan yüksek tutularak kademeli tavan yapılmıştır. Ahşap kirişlerin üzeri hasırla kaplanmıştır. Yapı önceden toprak damlı iken günümüzde kırma çat ile örtülmüştür (Cirtil, 2007: 115).

Çal Kocaköy Şalvan Câminde (18.yy-sonu-19.yy başı) orta sahın yanlardan yüksek tutularak kademeli tavan şeklinde yapılmıştır (Resim 26. a-b).

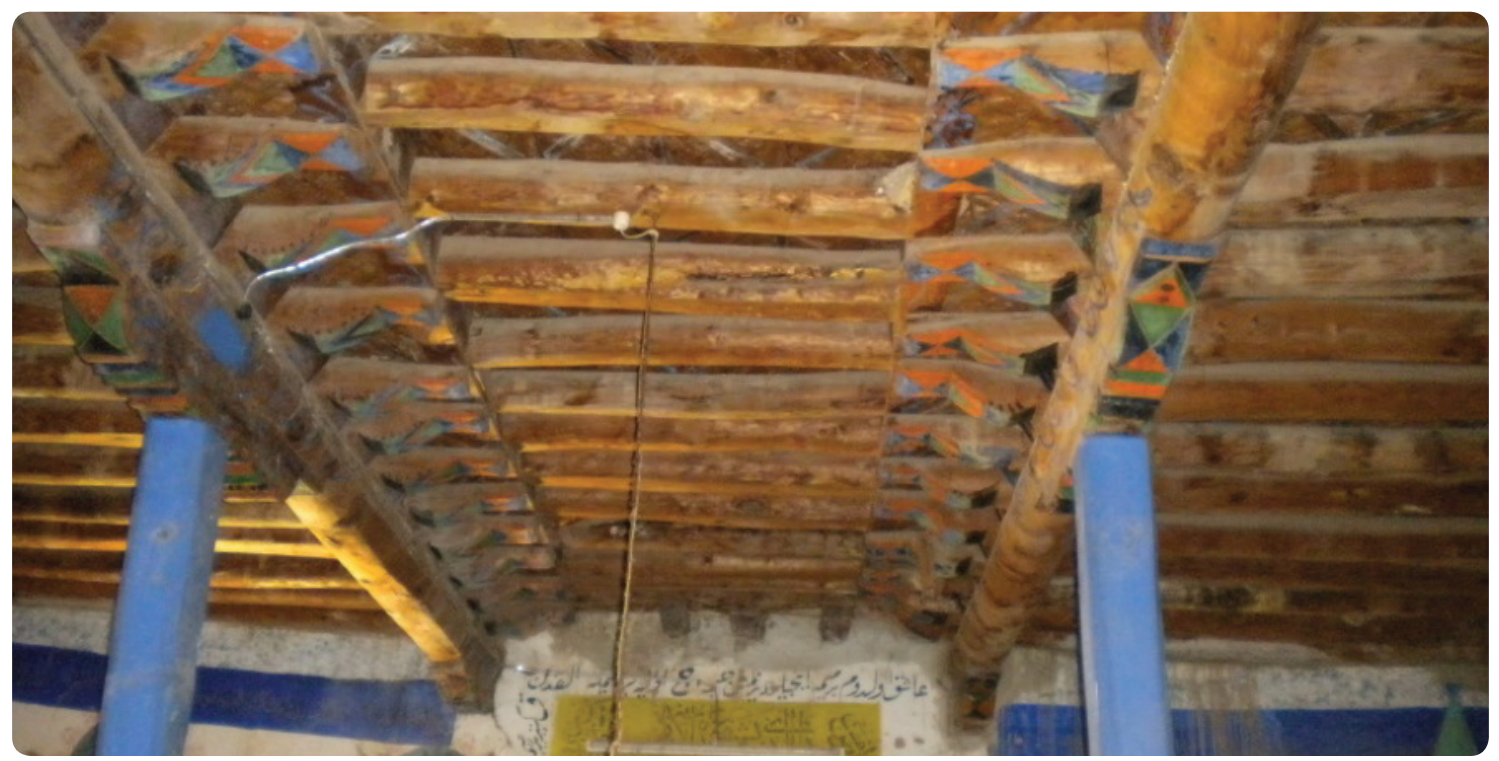

Resim 25. Bayat Köyü Câmi
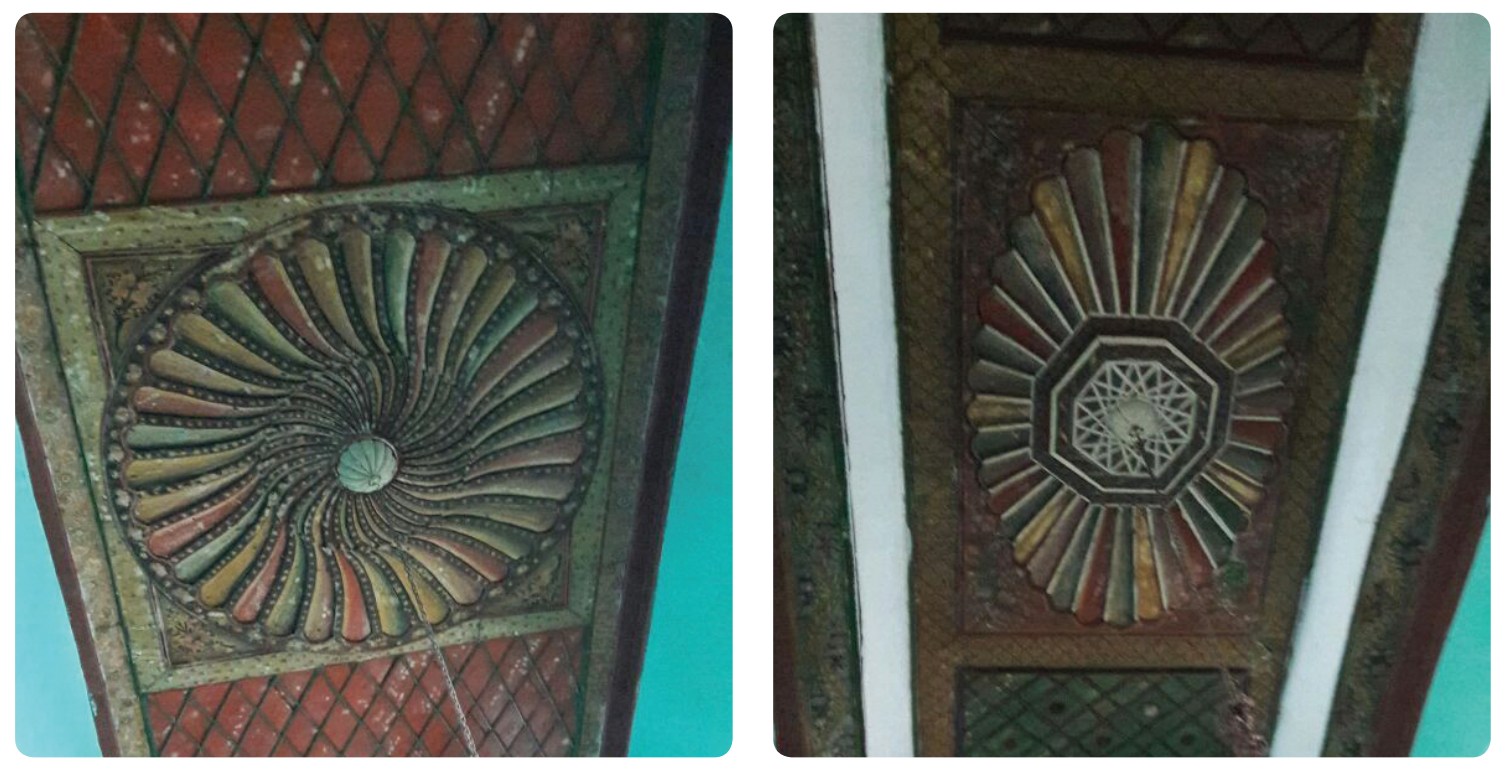

Resim 26. a-b Çal Kocaköy( Şalvan) Câmi Orta ve yan sahın tavanları.

11 (http://www.pamukkale.gov.tr/DE/page/kultur_cami. html.14.03.2017) 
Güney Belenardıç Köyü Câminde (1884 Baklan Tekke Câmi'nde (18.yy-sonu-19.yy başı) M./R.1300) Dört sahınlı yapıda ortadaki iki de desteklere oturan profilli, yastıkların üzerinsahın konsollarla yükseltilerek kademeli tavan şeklinde yapılmıştır (Resim 27a-b). Yapıların dış örtüsü düz toprak damlı iken, dönem dönem yapılan onarımlar sırasında kırma çatı ile örtülerek kiremit kaplanmıştır. de kuzey-güney yönlü ana kirişler yer almakta olup, bunları doğu-bat yönlü yan kirişleri taşır (Resim 28 ${ }^{12}$ ). Tavan kirişlemesi üstten yapılmıştr. Bir sıra konsolla orta sahın tavanı kademeli yapılmıştır. Dıştan kırma çatılı ve kiremit kaplıdır.
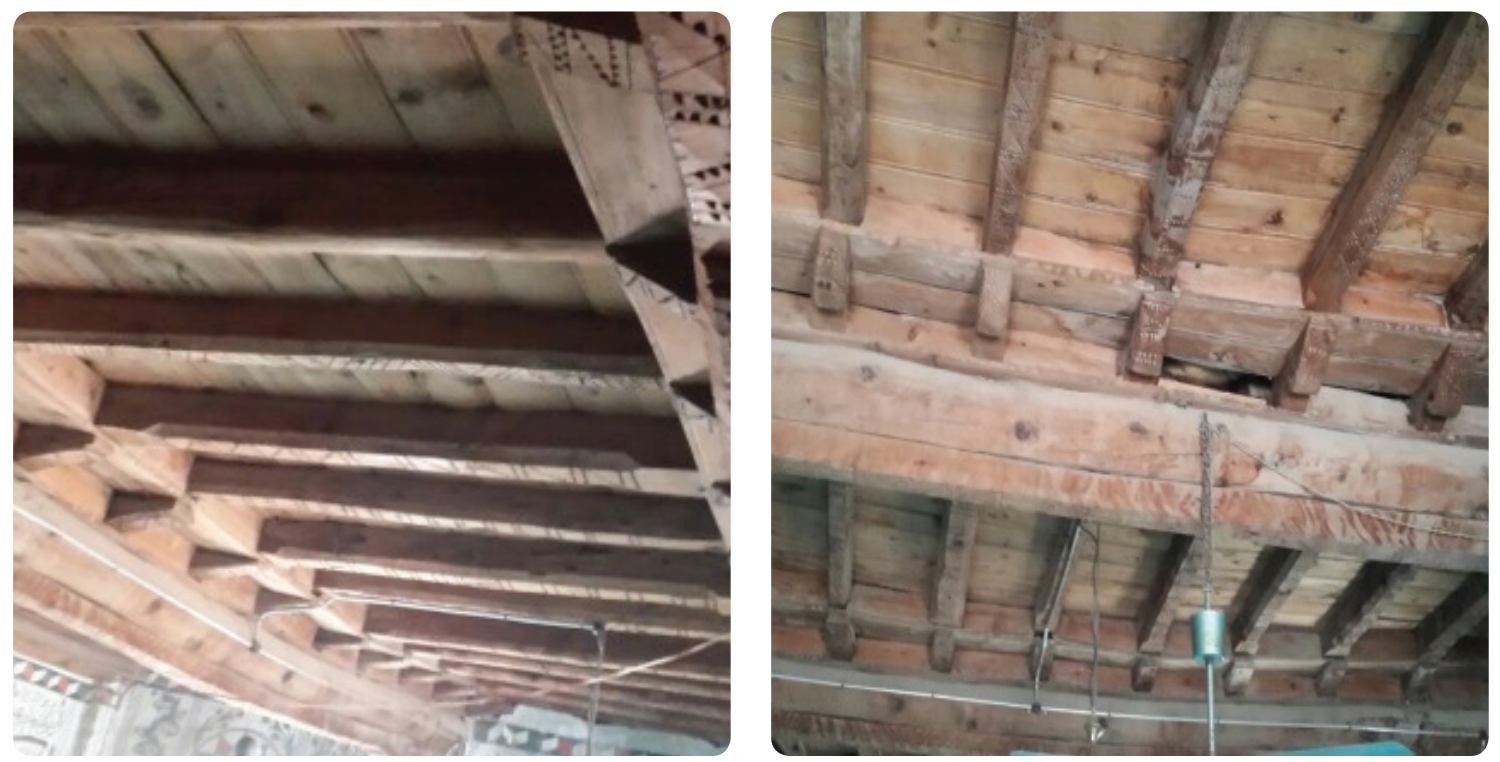

Resim 27. a-b Güney Belenardıç Köyü Câmi Tavan (4 Nisan 2017)

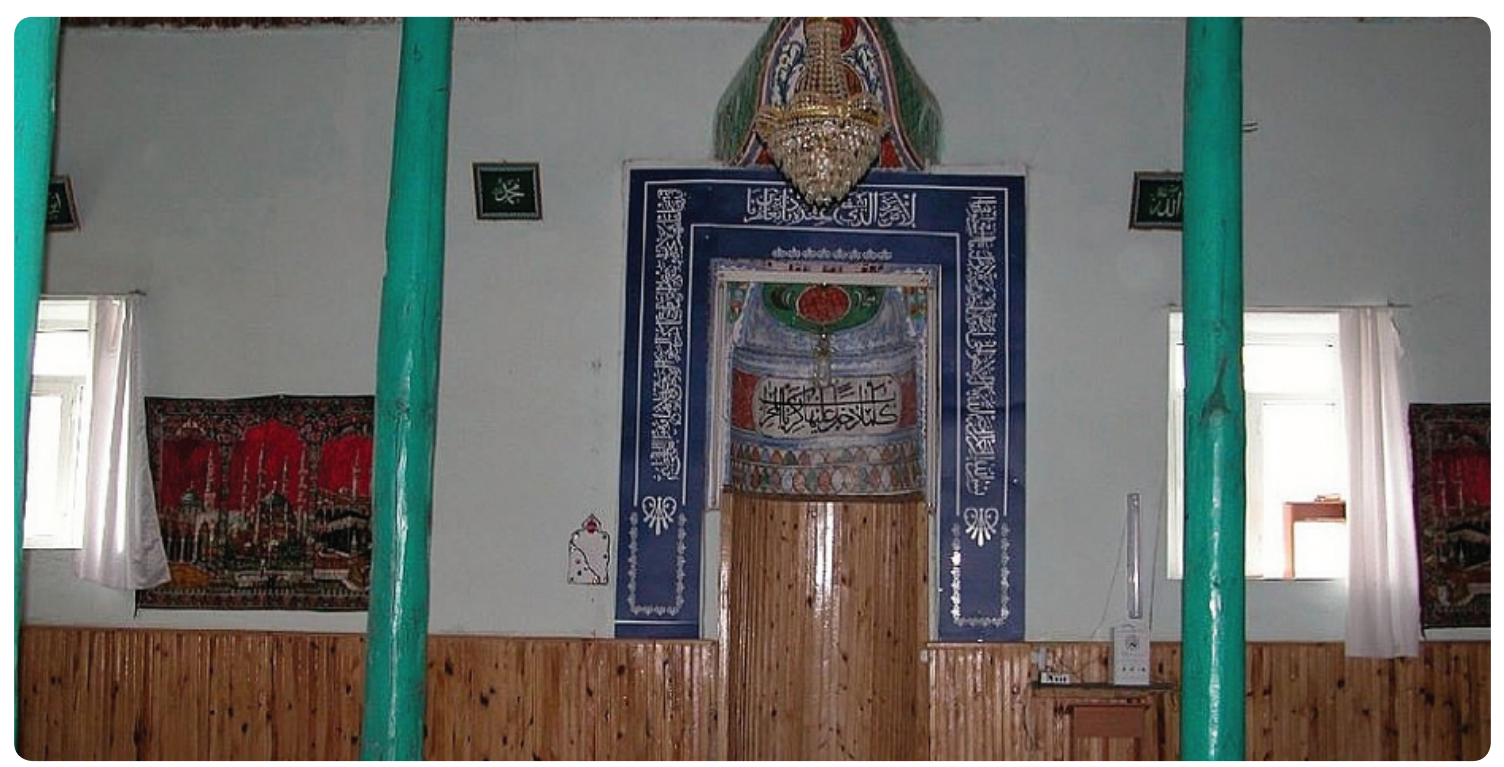

Resim 28. Baklan Tekke Câmi

12 http://www.pamukkale.gov.tr/DE/page/kultur_cami. html.18.11.2012 


\section{Düz Tavanlı Câmilerde Taşıyıcılar}

\section{a. Duvarlar}

Düz ahşap tavanlı desteksiz Câmilerde duvarlar taşıyıcı işlevi görmekte olup, kesme taş, moloz taş, kaba yonu, kerpiç, tuğla ve ahşap malzemenin kullanıldığı görülür. Duvarlar kerpiç yığma, moloz taş yığma veya kaba yonu yığma veya kesmetaş şeklinde yapıldığı gibi, çoğu yapıda ahşap hatılların kullanıldığı dikkati çeker. Yapılardaki duvar kalınlıkları 0,56 ile 0,92 m. arasında değişmektedir. ${ }^{13}$ Tavas Ulukent Câmi'nin duvarlarında moloz taş malzeme kullanılmıştır ve plan üzerinden duvar kalınlığının 0,80-0,85 m. olduğu saptanabilmiştir. ${ }^{14}$

Serbanşah Câmi'nde (18.yyılın üçüncü çeyreği) duvarlar pencere alt seviyesine kadar içten moloz taş ve tuğla, dışta ise muntazam blok taşlarla örülüdür. Bu kesimden yukarısı ise kerpiç örgülü olup, aralarına yatay yerleştirilmiş ahşap hatıllarla inşa edilmiştir. Duvar kalınlığı $0.70 \mathrm{~m}$. ile $0.74 \mathrm{~m}$. arasında değişmektedir.

Yazır Çarşı Câminde (1802 M./H.1217) ise malzeme olarak bütün beden duvarlarında moloz taş, arada ahşap hatillarla kullanılmış olup, duvar kalınlığı 0,87 m.dir.

Kale Cevher Paşa Câmi (1819-20M./H.1235) ve Pazar Yeri Câmi duvarlarında kaba yonu taş, moloz taş, pencerelerdeki atkı taşlarıyla mihrapta kesme taş kullanılmış olup duvar kalınlığı yapının tüm beden duvarlarında 0,84 m.'dir.

Baklan Tekke Câmiinde (18.yy-sonu-19.yy başı) ise yapının inşasında tamamen moloz taş kullanılmıştır. Çal Kuyucak Köyü ve Bekilli Çoğaşlı Köyü Câmilerinde yapının tamamında moloz taş kullanılmış olup ahşap hatıllarla desteklenmiştir.

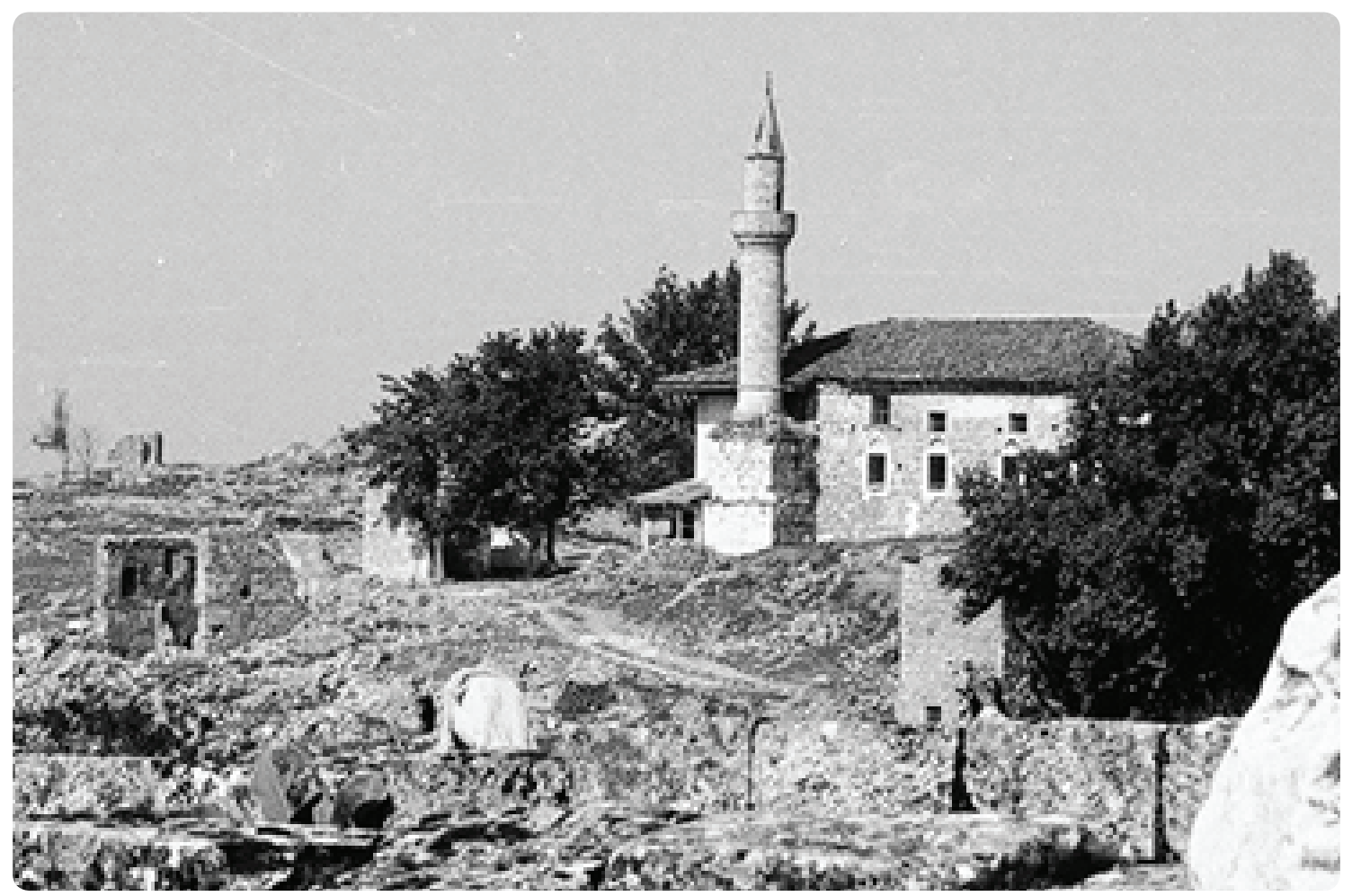

Resim 29. Kale Pazaryeri Câmi (VGMA, 20: 1968)

13 Duvar kalınlıkları ilgili yapıların VGM Arşivindeki planlarınlarından edinilmiştir.

14 http://www.pamukkale.gov.tr/DE/page/kultur_cami. html.18.11.2012 
Tablo 3. Düz tavanlı câmilerin duvar örgüsünde kullanılan malzemeler.

\begin{tabular}{|c|c|c|}
\hline Çivril & Gümüşsu Dere Câmi & moloz taş temel üzerine kerpiç arası ahşap hatıllar \\
\hline Acıpayam & Apa Câmi & moloz taş temel üzerine kerpiç arası ahşap hatıllar \\
\hline Acıpayam & Yassıhöyük Câmi & moloz taş temel üzerine kerpiç arası ahşap hatıllar \\
\hline Acıpayam & Yazır Câmi & moloz taş, arada ahşap hatıllar \\
\hline Akköy & Yukarı Câmi & kabayonu-kerpiç \\
\hline Babadağ & $\begin{array}{l}\text { Hamidiye Ovayurt Taraş, } \\
\text { Babadağ Aşağı Tepeardı, } \\
\text { Yukarı Kuzere Câmileri }\end{array}$ & kesme taş \\
\hline Babadağ & Kırçıtaş ve Düvenönü Câmileri & kesme taş-tuğla \\
\hline Baklan & Tekke Câmi & moloztaş \\
\hline Bekilli & Çoğaşı Köyü Câmi & moloztaş- ahşap hatillar \\
\hline Buldan & Çarşı ve Hacı Bekir Câmileri & moloz taş temel üzerine kerpiç arası ahşap hatıllar \\
\hline Buldan & Dört Eylül Câmi & kesme taş-kabayonu \\
\hline Buldan & Ali Ağa Câmi & kesme taş-moloz taş \\
\hline Buldan & Avdan Baba Câmi & kabayonu-moloz taş \\
\hline Çal & Çarşı Câmi & kesme taş \\
\hline Çal & Kuyucak Köyü Câmi & moloztaş- ahşap hatıllar \\
\hline Çardak & Gemiş Köyü Câmi & moloz taş temel üzerine kerpiç arası ahşap hatıllar \\
\hline Çivril & Serbanşah Câmi & $\begin{array}{l}\text { moloz taş ve tuğla, dışta, blok taş, kerpiç, ahşap } \\
\text { hatillar }\end{array}$ \\
\hline Denizli & $\begin{array}{l}\text { Ulu Câmi }{ }^{10}, \text { Kiremitçi, } \\
\text { Akkonak, Öküzbatt,, } \\
\text { Hatipoğlu, Odun Pazarı, } \\
\text { Saraylar Mahallesi, } \\
\text { Değirmenci Câmileri }\end{array}$ & moloz taş temel üzerine kerpiç arası ahşap hatıllar \\
\hline Denizli & $\begin{array}{l}\text { Kuşpınar Hasan Fevzi Efendi } \\
\text { Câmi }\end{array}$ & kesme taş-tuğla-kabayonu \\
\hline Denizli & İncekara Câmi & moloztaş-kerpiç tuğla \\
\hline Güney & $\begin{array}{l}\text { Çarşı, Hacı Habib, Çolacık, } \\
\text { Said Ağa, Mestan, Hacı } \\
\text { Hüseyin, El-Hac Hasan ibn el- } \\
\text { Hac Halilzade Câmi }\end{array}$ & kesme taş, kaba yonu ve moloz taş (?) \\
\hline Kale & $\begin{array}{l}\text { Pazaryeri Câmi ve Cevher } \\
\text { Paşa Câmi }\end{array}$ & $\begin{array}{l}\text { kesme taş-devşirme-moloz taş ve kabayonu ahşap } \\
\text { hatıllar }\end{array}$ \\
\hline Kızılcabölük & Hanönü Câmi & moloz taş temel üzerine kerpiç arası ahşap hatıllar \\
\hline Tavas & Ulukent & moloztaş \\
\hline Tavas & Aydoğdu Köyü Câmi & moloz taş temel üzerine kerpiç arası ahşap hatıllar \\
\hline Tavas & $\begin{array}{l}\text { Çayırlık, Kavaklı, Yukarı } \\
\text { Câmileri }\end{array}$ & moloz taş temel üzerine kerpiç arası ahşap hatıllar \\
\hline Sarayköy & Çarşı Câmi & tuğla-kabayonu \\
\hline Sarayköy & $\begin{array}{l}\text { Hükümetönü, Sarayköy } \\
\text { Hasköy }\end{array}$ & moloz taş temel üzerine kerpiç arası ahşap hatıllar \\
\hline
\end{tabular}


Güney İlçesindeki desteksiz düz ahşap tavanlı Câmilerden sadece Çarşı Câmi'nin duvar kalınIığı (0,70 m.), Dere, Çolacık, Said Ağa, Mestan, Güney el-Hac Hasan ibn el-Hac Halilzade, Hacl Habib Câmilerinde de 0,75-0,80 m. arasında değişmektedir. Duvarlar tamamen sıvalı olduğu ve hakkında başka bir yayın bulunmadığı için malzeme konusunda herhangi kesin bir bilgiye ulaşılamamıştr. Ancak yöre mimarisine bakıldığında kesme taş, kaba yonu ve moloz taş malzeme ile duvarların yığma olarak yapılmış olduğu kanaatini kuvvetlendirmektedir.

\section{b. Destekler}

Denizli ve çevresindeki düz tavanlı câmilerde destek kullanımına bakıldığında 4 ile 12 arasında değişmektedir. Destekler kare, yuvarlak ve sekizgen şeklindedir. Yedi yapıda destekler duvardan tamamen bağımsız, altı yapıda bazen iki bazen dört destek duvarlara bitişiktir.

Tablo 4. Düz tavanlı câmilerde destekler

\begin{tabular}{|c|c|c|c|c|c|c|c|c|}
\hline \multirow{2}{*}{ Yapı adı } & \multirow{2}{*}{ Tarihi } & \multirow{2}{*}{$\begin{array}{c}\text { Destek } \\
\text { sayısı }\end{array}$} & \multicolumn{3}{|c|}{ Şekli } & \multirow{2}{*}{ Çapı } & \multirow{2}{*}{ Serbest } & \multirow{2}{*}{ bitişik } \\
\hline & & & Kare & yuvarlak & sekizgen & & & \\
\hline Tavas Ulukent Câmi & 1530 & 4 & 4 & & & $\begin{array}{c}0,23-0,24 \\
\mathrm{~m} .\end{array}$ & 2 & 2 \\
\hline Çivril Bayat Köyü Câmi & 1872 & 4 & 3 & 1 & & & 2 & $2^{11}$ \\
\hline $\begin{array}{l}\text { Bekilli Çoğaşlı Köyü } \\
\text { Câmi }\end{array}$ & 1743M./H.1156 & 6 & & & 6 & & 6 & \\
\hline Çivril Serbanşah Câmi & $\begin{array}{l}\text { 18.yyılın üçüncü } \\
\text { çeyreği }\end{array}$ & 6 & & 6 & & $0,30-0,33 m$ & 6 & \\
\hline $\begin{array}{l}\text { Baklan Boğaziçí } \\
\text { Çalkebir Eski Câmi }\end{array}$ & 1774-75 M./H.1186 & 8 & 2 & 6 & & & 6 & \\
\hline $\begin{array}{l}\text { Acıpayam Yazır Çarşı } \\
\text { Câmindeki }\end{array}$ & 1802M./H.1217 & 10 & & 10 & & $\begin{array}{c}0,32-0,35 \\
\mathrm{~m} .\end{array}$ & 6 & 4 \\
\hline Baklan Tekke Câmi & $\begin{array}{c}\text { 18.yy sonu-19 yy } \\
\text { başı }\end{array}$ & 12 & & 12 & & & 12 & \\
\hline $\begin{array}{l}\text { Baklan Çataloba Köyü } \\
\text { Câmi }\end{array}$ & $\begin{array}{c}\text { 18.yy sonu-19 yy } \\
\text { başı }\end{array}$ & 8 & 3 & 5 & & & 4 & 4 \\
\hline Kale Cevher Paşa Câmi & 1819M./H.1235 & 12 & & $12^{12}$ & & $33-36 \mathrm{~cm}$ & 10 & \\
\hline Çal-Şalvan Câmi & 19.yy başı & 8 & 3 & 5 & & & 4 & 4 \\
\hline $\begin{array}{l}\text { Bozkurt Baklan } \\
\text { kuyucak Câmi }\end{array}$ & $1814-15$ & 8 & 2 & 6 & & & 8 & \\
\hline $\begin{array}{l}\text { Güney Belenardıç } \\
\text { Köyü Câmi }\end{array}$ & 1884 & $14^{13}$ & 11 & & 3 & & 4 & 10 \\
\hline Çal Çarşı Câmi & 1903 & 4 & $4^{14}$ & & & & & \\
\hline Toplam & & 104 & 32 & 63 & 9 & & & \\
\hline
\end{tabular}


Düz tavanlı Câmilerden on üç câmide toplam yüz dört ahşap destek bulunmaktadır. Bunlardan otuz ikisi kare, altmış üçü yuvarlak, dokuzu sekizgen şeklindedir. Yapılardan sadece Çivril Savranşah Köyü Serbanşah Câmi'nde (18. yüzyılın üçüncü çeyreği) yuvarlak şekilli (Resim 30), Kale Cevher Paşa Câminde (1854 M./H. 1251.) kompozit (Resim 31), Bekilli Çoğaşlı Köyü Câminde (1743 M./H.1156.) kare prizmal şekilli (Resim 32) sütun başlığı şeklinde düzenlemeler mevcuttur.

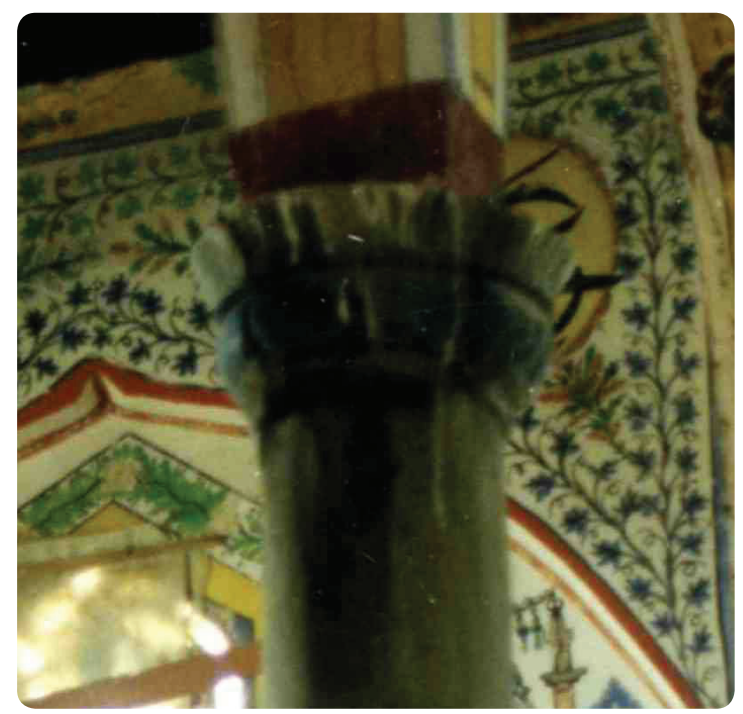

Resim 30. Çivril Serbanşah Câmi sütun başlığı.

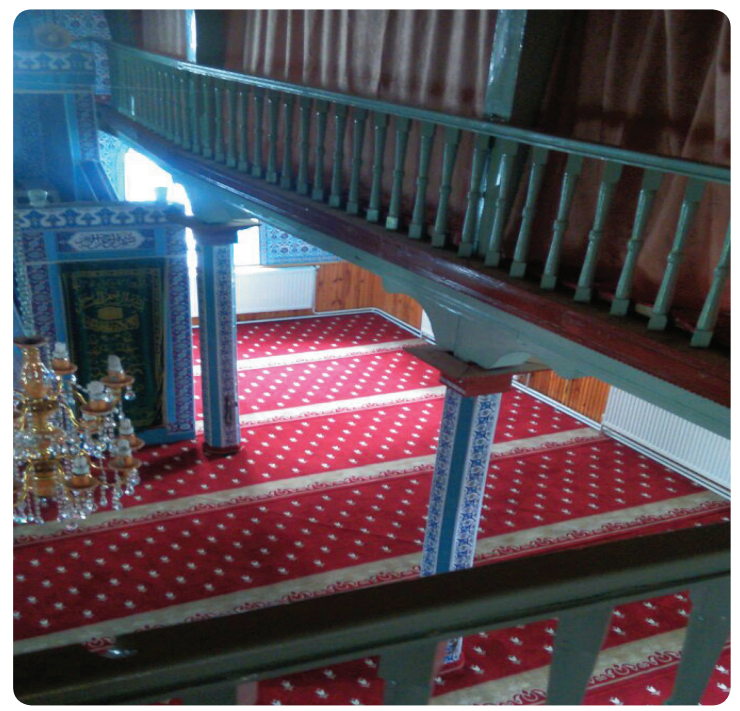

Resim 32. Bekilli Çoğaşlı Köyü Câmi (2017)
Yazır Kasabası Çarşı Câmi'nde on adet yuvarlak destekten ikisi kuzey, ikisi güney duvarına bitişik ve altısı bağımsızdır. 0,32 -0,35m. arasında değişen çaptaki destekler tek parça ahşaptan yapılmış ve tavana yakın yerde birer silmeden sonra 0,50 m.'lik dikdörtgen prizma şeklinde yukarı doğru daralan birer başlık görünümünde yükselmektedir (Resim 33). Benzer örnekler Kale Cevher Paşa Câmi'nde sütun başlıkları üzerinde de görülmekle birlikte bunun başıı olarak kabul edilip edilemeyeceği tartışmalıdır.

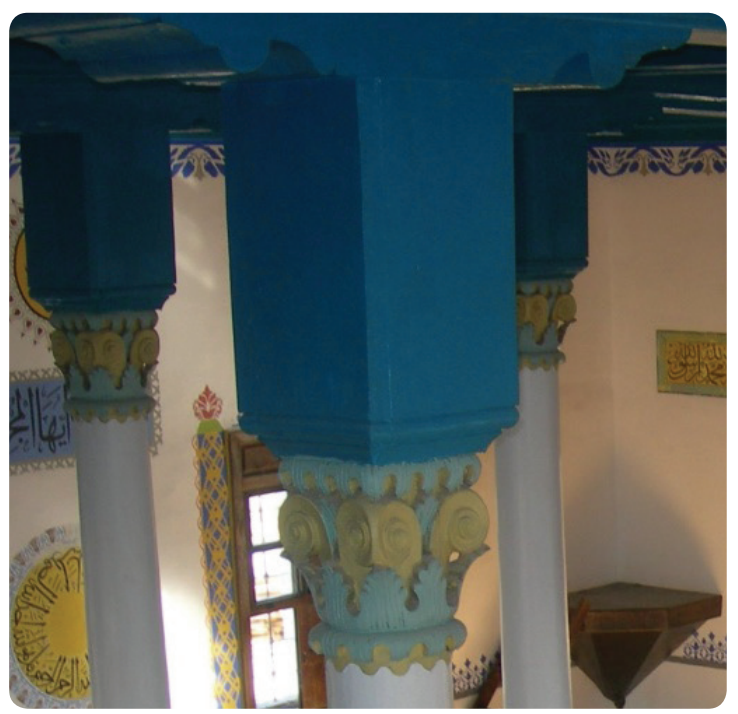

Resim 31. Kale Cevher Paşa Câmi sütun başlığı.

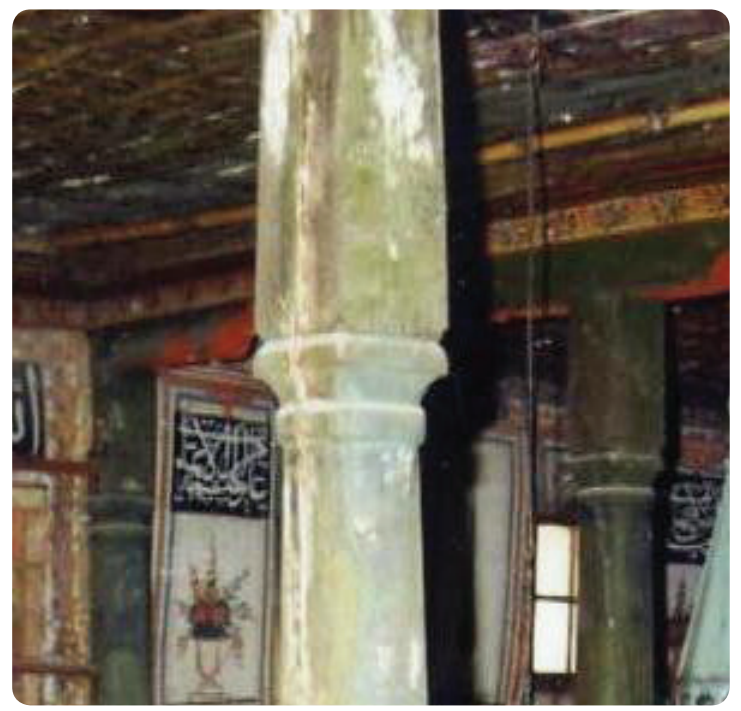

Resim 33.Yazır Beldesi Çarşı Câmi Ahşap Destekler (VGMA, 20: 2004) 
Çal Çarşı Câminde (19.yy başı) tonoz örtüyü taşıyan kare destekler üzerinde birer silmeden sonra kare prizmal şekilde başlık görünümü verilen bir bölüm oluşturulmuştur (Resim $\left.34^{15}\right)$.

Baklan Boğaziçi Çal Kebir Köyü Eski Câmi'nde (1774-75 M./H.1186) destekler, güney yöne doğru, ikinci ve üçüncü açıklıklar taşıyıcı olmayan dekoratif sivri kemerle, son açıklık ise aynalı kemerle kapatılmıştır.
Bozkurt Baklan Kuyucak Câminde (1743M. /H.1156) ise desteklerin 1989 yılına kadar birbirine üç dilimli dekoratif ahşap kemerlerle bağlı olduğu, onarım sırasında basit kemerler yapıldığı anlaşılmaktadır.

Çivril Serbanşah Câmi'nde (18.yüzyılın üçüncü çeyreği) destek araları taşıyıcı işlevi olmayan sivri ahşap kemerlerle kapatılmıştır (Resim 35).

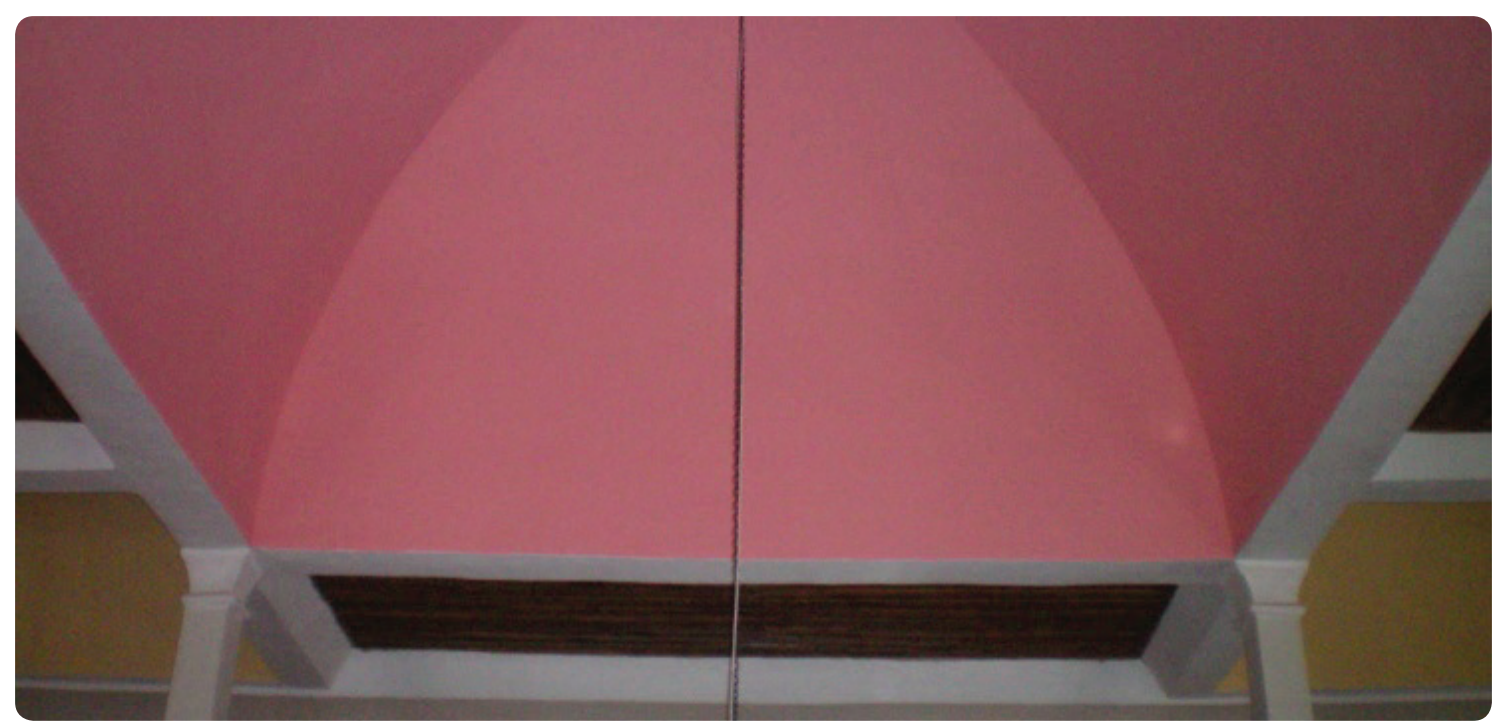

Resim 34. Çal Çarşı Câmi (30.11.2012)

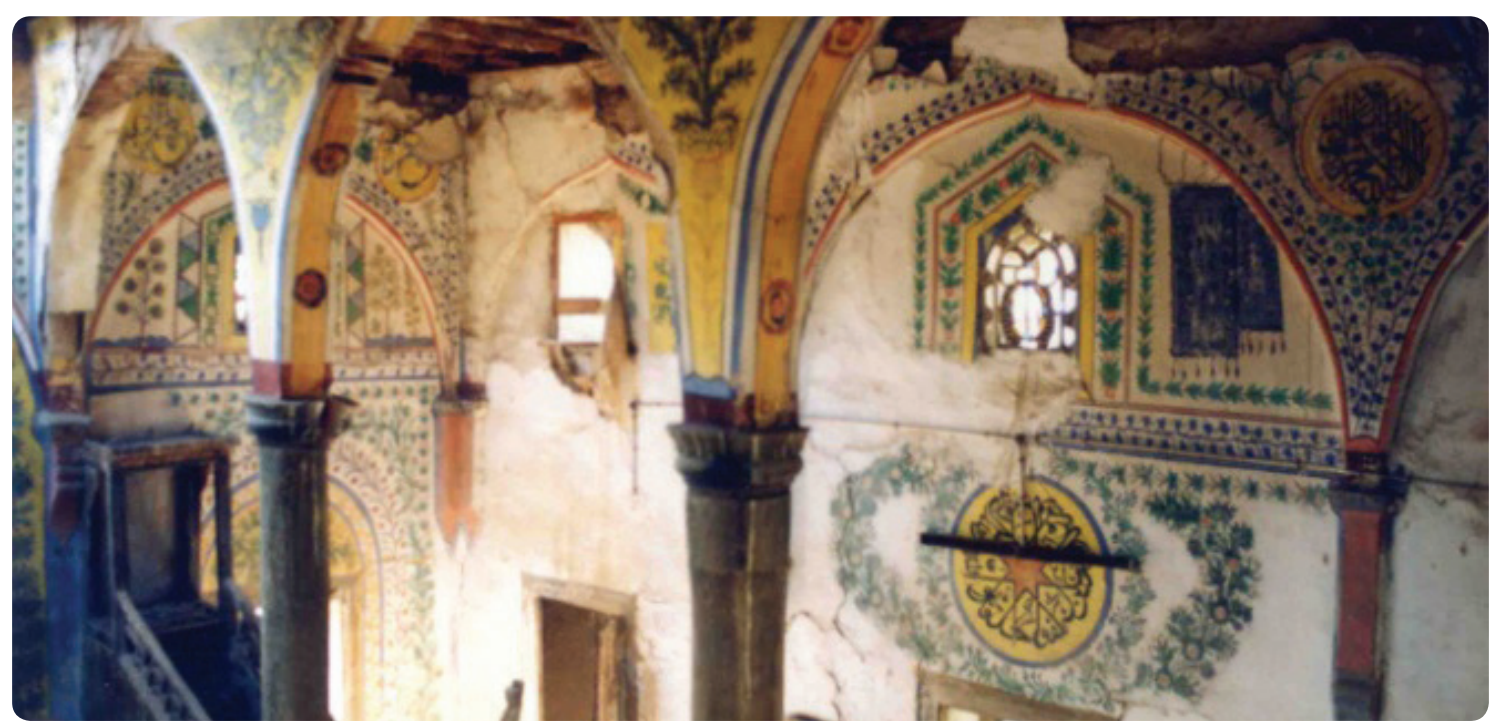

Resim 35. Çivril Serbanşah Câmi kemerler (VGMA, 20: 2001)

15. Fotoğrafları çekip gönderen Çarşı Cami Müezzini İbrahim Bozkurt ile müftülük görevlisi Hüsnü Üçkuyulu'ya teşekkür ederim. 
Çal Kocaköy Şalvan Câminde(18.yy-sonu-19. Çal Kuyucak Köyü Câminde de tavanı destekyy başı) aşağıdan yukarıya doğru daralan, kare leyen ahşap direklerin çokgen formda olduğu prizmal başlıklara oturan yuvarlak kemerlerle anlaşılmaktadır (Resim 37). orta ve yan sahınlar ayrılmıştı (Resim 36).

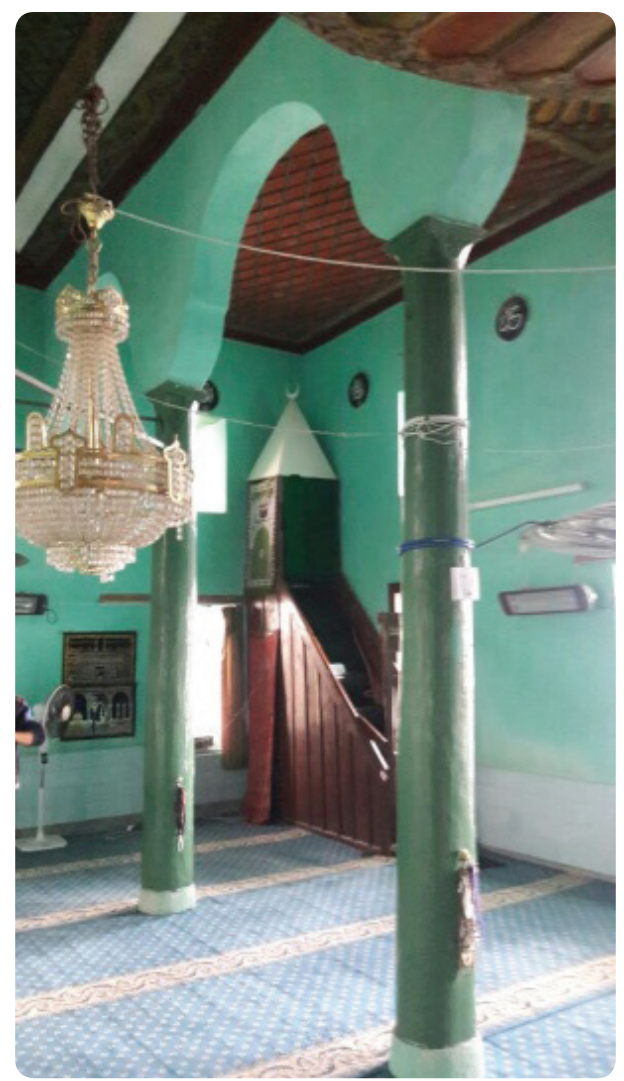

Resim 36. Çal Kocaköy Şalvan Câmii Destekler (6 Nisan 2017)

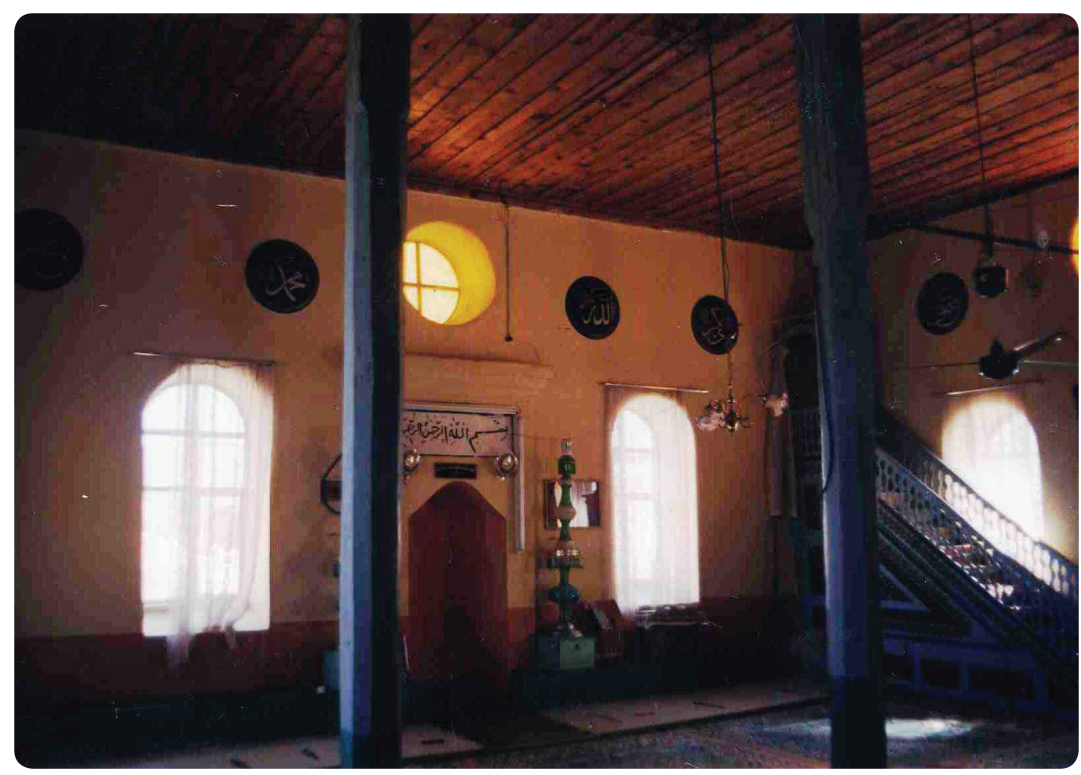

Resim 37. Çal Kuyucak Köyü Câmi Destekler (VGMA,20:2004). 


\section{Kubbeli Câmiler}

Yapılan çalışmada Denizli ve çevresindeki câmilerden diğer bir grubu kubbeli câmiler oluşturmaktadır. Honaz Sultan Murad Câmi (15-16. yy), Çivril Dedeköy Emirhisar Câmi (15.-16. yy), ${ }^{16}$ Tavas Hırka Köyü Câmi (1860-61M.) ${ }^{17}$ Çivril Çarşı Câmi (1903), Kayalık (Eski Müftü) Câmi kubbeli Câmilerdendir.

\section{1. Örtü Düzeni:}

Bugün harap bir halde olan Honaz Sultan Murad Câmi 15-16 yüzyıı ${ }^{18}$ fotoğraflarında yapıda hari min kuzey-batı köşesinde içi üçgen bir kuşakla doldurulan ve günümüze ulaşabilen tromp kaIıntilarından ve yuvarlak formdan, üst örtünün kubbeyle örtülü olduğu anlaşılmaktadır (Resim 39). Dışta sekizgen olan kubbe kasnağı içte sekizgenin köşelerine yerleştirilen mukarnas dolgular aracılığıyla on altggene dönüştürülmüştür. Güney doğu ve güney bat köşelerdeki trompların sadece kemer başlangıçları seçilmektedir. Kubbeye geçiş sivri kemer şekilli büyük tromplarla sağlanmıştır (Resim 38).

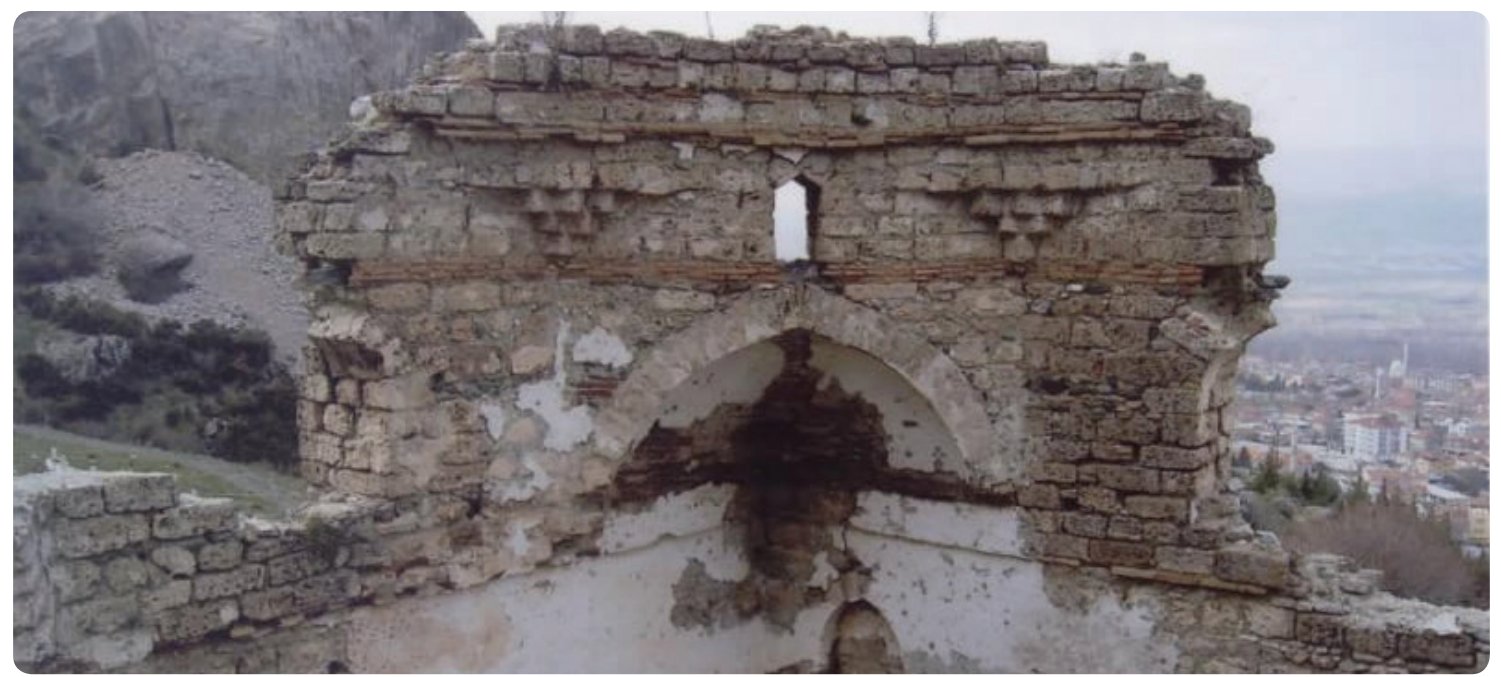

Resim 38. Honaz Sultan Murad Câmi*

16 Ayda Arel yapının 15. yüzyıl özellikleri gösterdiğini ve fetih dönemine ait olması gereken yapının bir külliyenin parçası olduğunu söyler (Arel, 1990: 5).

17 Söz konusu yapının tarihlendirmesi konusunda Vakıflar Genel Müdürlüğü uzmanlarından oluşan (Sanat Tarihçi Birsen Erat, restoratör Selçuk Tezcan ve Y. Mimar Aydın Y. Kesici) heyetin raporunda (201802001-RP003) yapının son cemaat yerinde bulunan girişin iki yanındaki mukarnas kavsaralı iki mihrabiye ve duvar üzerinde bulunan dört konsol ile döşeme üzerinde bulunan dört sütun alınlığından aslında üç birimli, üç kubbeli bir biçime sahip olduğu, 1991 yılında mevcut olan sonraki bir dönemde yapılan son cemaat yerinin de korunmaya değer özellikte olduğunu, ancak aslına uygun kubbeli bir proje çizilerek kurulun onayına sunulması ve konuyla ilgili son kararın yerinde yapılacak bir incelemeden sonra verilmesi önerilmiştir.

18 Çakmak, Denizli ve çevresinin 1429 yılında II. Murad Döneminde Osmanlı hakimiyetine girdiğini, Sultan Murad'ın burada bir cami yaptırma ihtimalinin olabileceğinden söz eder. Evliya Çelebi'nin ise Honaz'da iki camiden söz ettiğini, Kale içindeki Kurşunlu caminin bu cami olması intimal dahilinde olduğunu ve yapının 15.yyıl-17 yüzyıl zaman aralığında yapılmış olabileceğinden söz eder (Çakmak, 1991: 18).

* www.kulturportali.gov.tr/turkiye/denizli/gezilecekyer/sultan-murad-cami 10.04.2017
Çivril Emirhisar Dedeköy Câmi (15.-16.yy) kare planlı kubbeli bir yapıdır. Kubbe dışta sekizgen bir kasnağa oturmakta olup, her kenarda yuvarlak kemerle kuşatılmış dikdörtgen birer pencere vardır. İçerde ise kubbeye geçişler oldukça büyük tromplarla sağlanmakta ve içlerinde birer gergi kirişi bulunmaktadır. Tromplar arasında ise üçgen kısımlar yer alır. Sekizgen kasnağa oturan kubbenin yükleri, pişmiş toprak kaplarla hafifletilmiş pandantiflerle karşılanmaktadır (Arel, 1990: 5). 
Yapı oldukça harap bir halde iken, 2004 yılında Vakıflar Genel Müdürlüğü tarafindan onarılmıştır (Resim 39a-b-c).

Tavas Hırka Köyü’nde bulunan câmi kare planlı ve kubbe ile örtülüdür. Kubbe dışta sekizgen bir kasnağa sahiptir. Kasnağın her kenarının ortasında sivri kemerli birer sağır pencere yer al

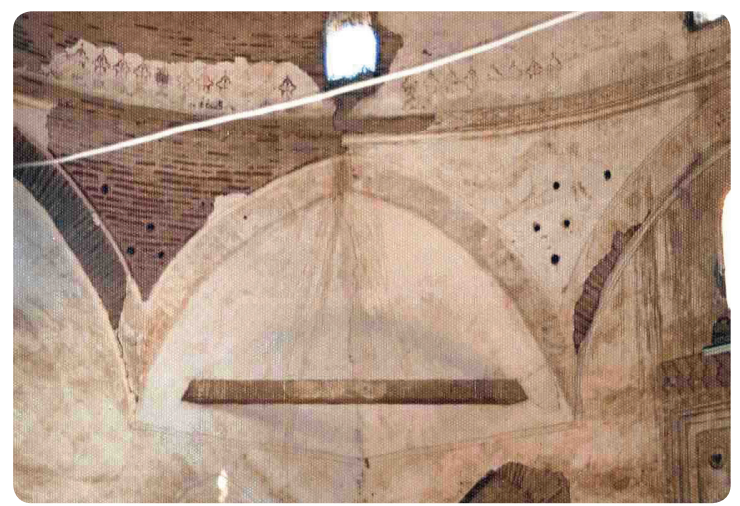

Resim 39 a-b. Çivril Emirhisar Dedeköy Câmi Kubbe (VGMA, 20: 2003)

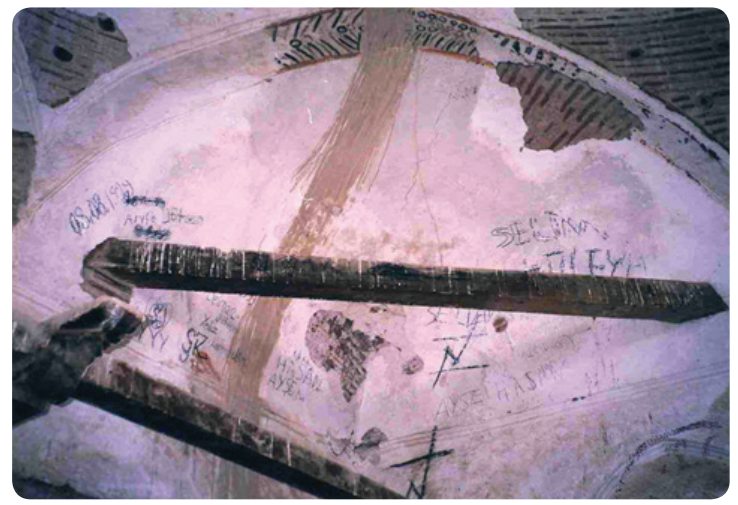

Resim 39 c. Çivril Emirhisar Dedeköy Câmi Kubbe (VGMA, 20: 2003)

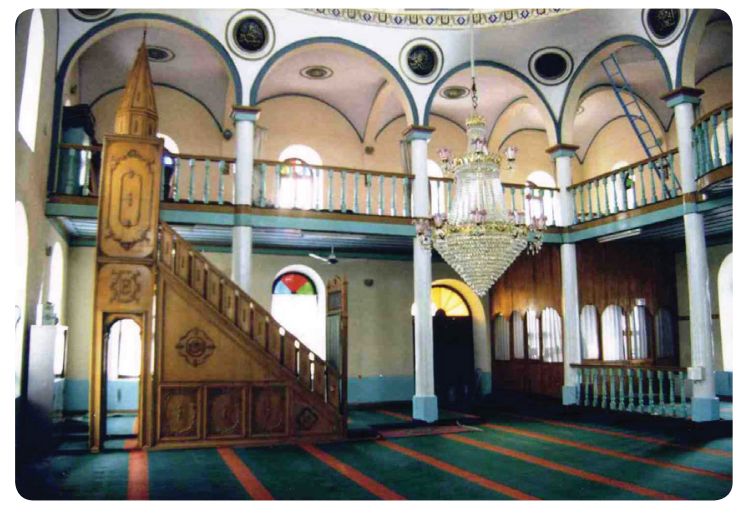

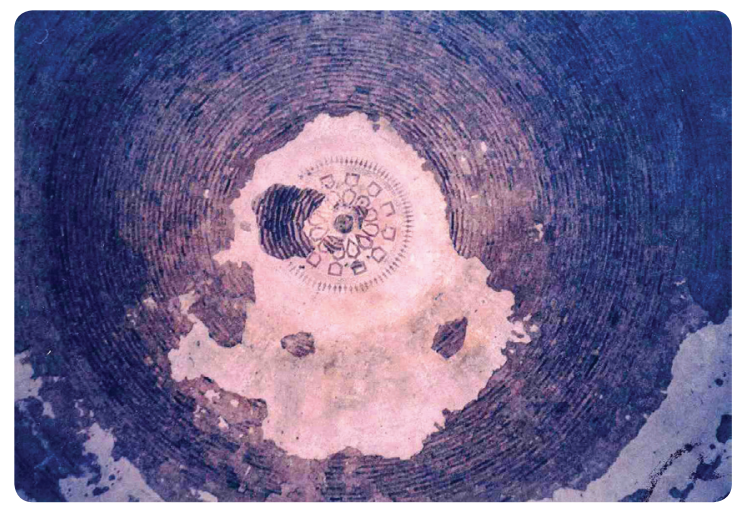

maktadır. Kubbeye geçiş içerde oldukça büyük yivli tromplarla sağlanmıştır (Resim 40 ).

Denizli Kayalık Müftü Câminde orta mekân, büyük bağdadi bir kubbe ile örtülmekte olup doğu, bat ve kuzeyde etrafinı bağdadi beşik tonozlu mekânlar kuşatır. Kubbe dıştan kurşunla, tonozlu mekânların üzeri çatılı ve kiremit kaplıdır (Resim 41a-b).

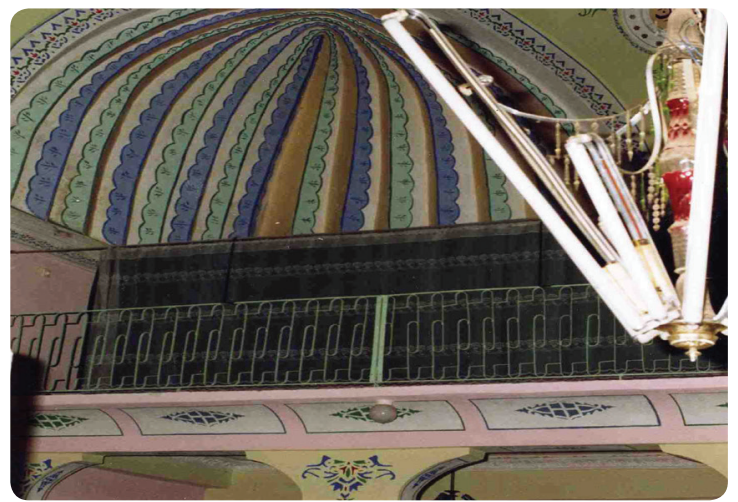

Resim 40. Tavas Hırka Köyü Câmi kubbeye geçişler (VGMA,20:2004).

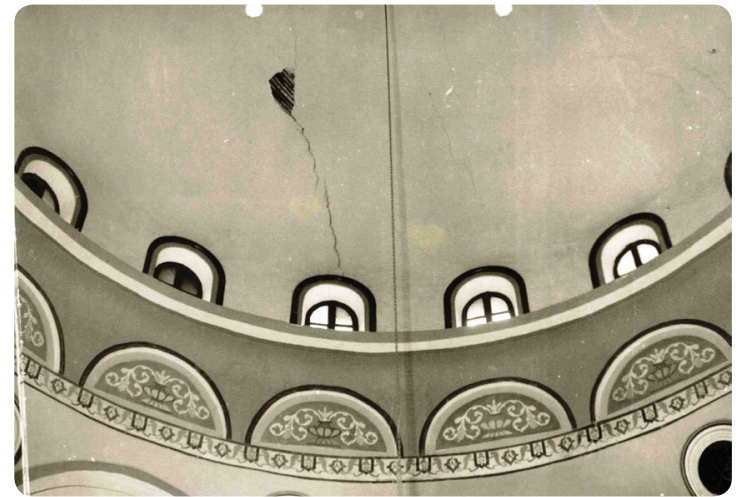

Resim 41 a-b. Denizli Kayalık Müftü Câmi-kubbe (VGMA, 20: 2004; 20: 1999). 
Çivril Çarşı Câminde harimi içten örten bağdadi kubbe dıştan sekizgen yüksek bir kasnakla kuşatılmış ve her cephede sivri kemerli birer pencere açılmıştır. Kasnağın üzerinde bulunan sekiz dilimli piramidal çat ise kiremitle kaplıdır. İçerideki bağdadi kubbeye geçiş trom plarla sağlanmıştır (Resim 42a-b- 44).

\subsection{Duvarlar}

Honaz Sultan Murad Câminde kubbe duvarlar tarafindan taşınmaktadır. Günümüzde harap bir halde olan yapıda kaba yonu, moloz taş, tuğla, tromplarda tuğla, kasnakta ve kubbede dönüşümlü kaba yonu ve tuğla malzeme kullanılmıştır (Çakmak, 1991: 15).

Emirhisar- Dedeköy Câminde de yine kubbe duvarlara oturmakta olup duvar kalınlığı 1,461,50 m.dir. Duvarlarda devşirme blok taşlar, kaba yonu, kesme taş, mermer, kubbe, kemer ve tromplarda tuğla, kullanılmıştır (Resim 44). Kasnakta kaba yonu üç sıra tuğla şeklinde almaşık örgü görülmektedir. ${ }^{19}$

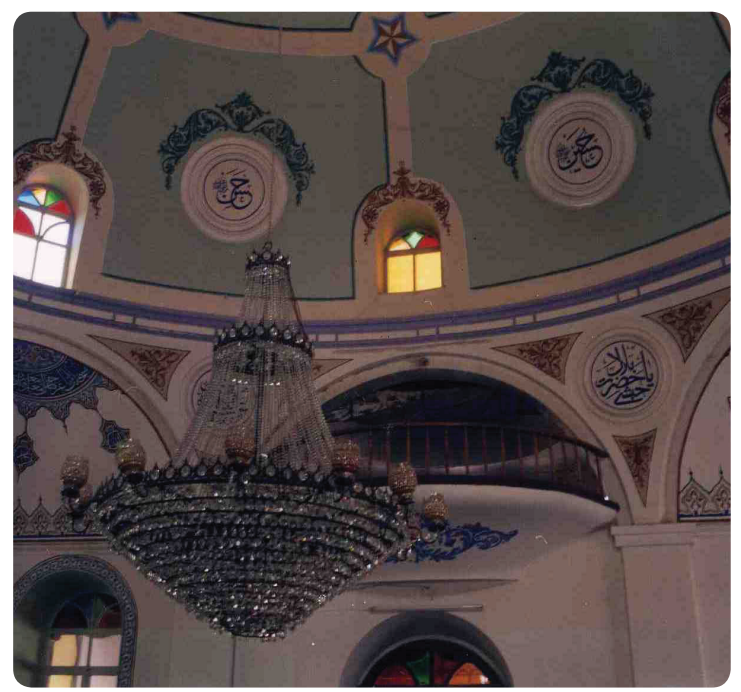

Resim 42 a-b. Çivril Çarşı Câmi bağdadi kubbesi (VGMA, 20: 2004)

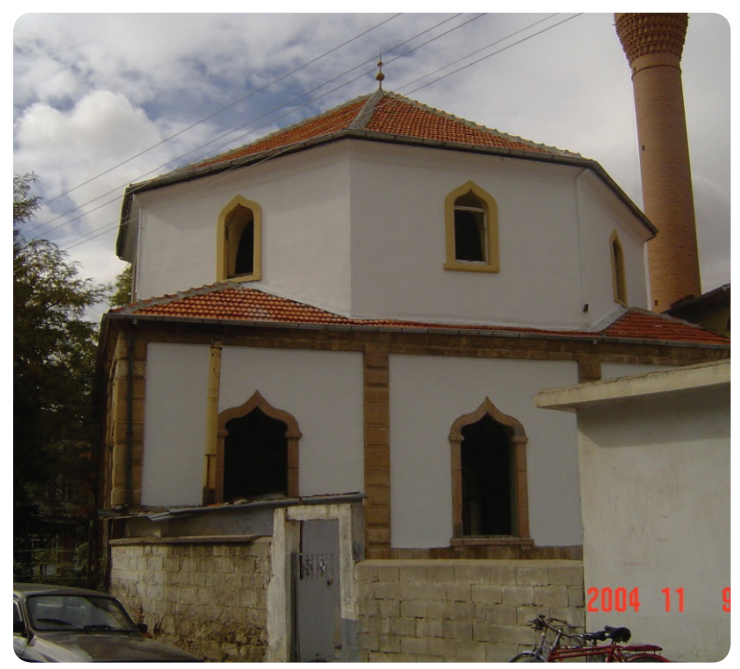

Resim 43. Çivril Çarşı Câmi onarım sonrası (VGMA, 20: 2004).

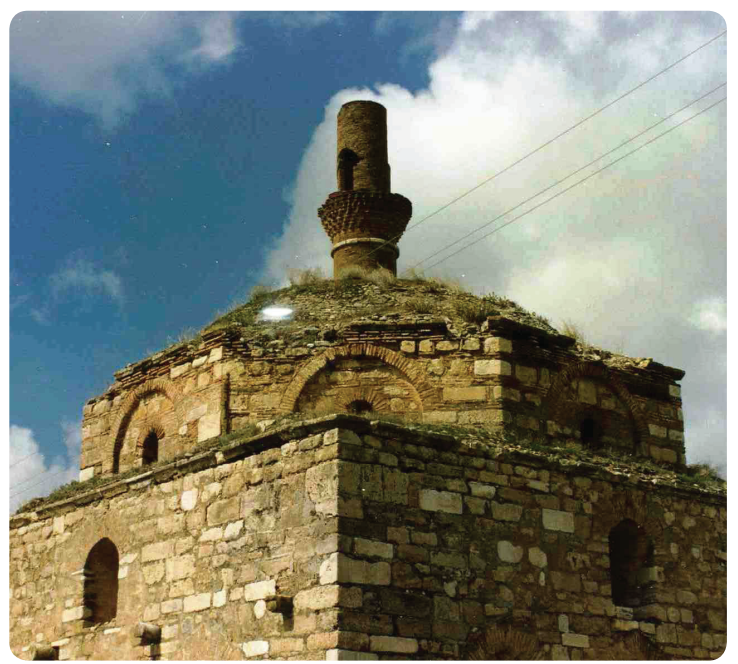

Resim 44. Çivril Dedeköy Emirhisar Câmi (VGMA, 20: 2003)

19. Arkeolog Nesrin Karabay ve Arkeolog Cevdet Sevinç tarafindan hazırlanan 09.04.2006 tarihli envanter fişi. 
Tavas Hırka Köyü Câminde de kubbe 1,47-1,67 m. arasında değişen kalınlıktaki duvarlar tarafindan taşınmaktadır. Duvarlarda kabayonu taş, moloz taş, yer yer kesme taş, pencere atkıları ile harimin giriş açıklığında devşirme mermer kullanılmıştır (Resim 45a-b).

Denizli Merkez Kayalık Eski Müftü Câmi, kare planlı 11m.çapında, yerden 16 m.yüksekliğinde bağdadi kubbeli bir yapıdır. Kubbe, güneyde duvarlar diğer üç yönde 5,5 metre uzunluğundaki sekiz yuvarlak ahşap destek tarafindan taşınmaktadır. Destek araları bağdadi yuvarlak kemerlerle kapatımıştır. Kubbe dışarıdan kurşun ile kaplıdır. On altggen kubbe kasnağında on alt pencere mevcuttur. Kubbeyi doğu-bat ve kuzeyden bağdadi beşik tonozlu mekânlar kuşatır. Duvarlar yığma olarak kesme taştan inşa edilmiş ve kalınlığı 0,72m'dir.

Çivril Çarşı Câminde (1903) ise bağdadi kubbeyi taşıyan beden duvarları kesme taştan inşa edilmiştir. Kubbe ve tromplar ise bağdadi olarak yapılmıştır.

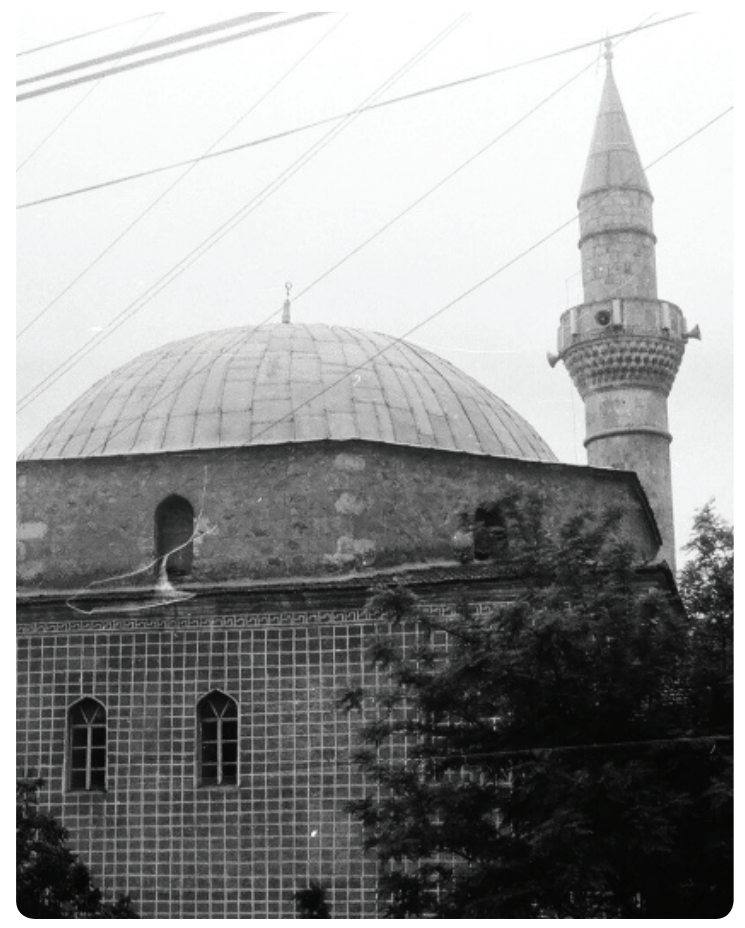

\section{Karşılaştırma Ve Değerlendirme}

Denizli ve çevresinde bulunan, Vakıflar Genel Müdürlüğü Arşivinden elde edilen her tür belge (resim, plan, rapor vb) ile diğer araştırma ve yayınlardan da yararlanılarak ele alınan bazı Câmiler yapı elemanları açısından değerlendirilmiştir. Yapılar düz tavanlı ve kubbeli Câmiler olarak gruplandırılmıştır. Bu bağlamda yetmiş bir düz tavanlı, beş kubbeli Câmi tespit edilmiştir.

Düz tavanlı Câmilerde kendi içerisinde göbeksiz, tekne tavanlı, kubbeli tavanlı, kademeli tavanlı, çıtalı göbekli tavanlı ve tonozlu tavanlı şeklinde tasnif edilmişlerdir. Her iki ana grup düz tavanlı ve kubbeli Câmiler de örtü düzeni ve taşıyıcılar olarak alt başlıklar açılarak incelenmiştir.

\section{1. Üst Örtü Düzeni:}

İçte düz tavanlı Câmilerin üst örtü sistemine bakıldığında bir kısmının önceki dönemlerde toprak dam şeklinde olduğu ve zamanla yapılan onarımlar sonrasında hepsinin üzerine kırma çathlı yapılıp, kiremitle örtüldüğü öğrenilmiştir.

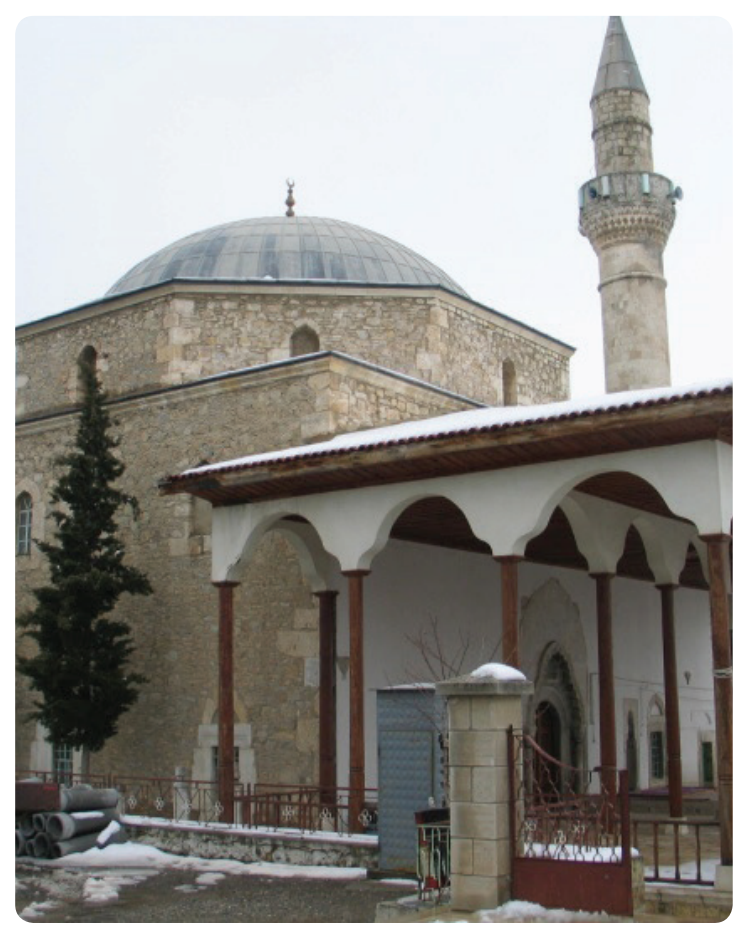

Resim 42 a-b. Çivril Çarşı Câmi bağdadi kubbesi (VGMA, 20: 2004) 
Tavanlarda tamamen düz tavan, düz tavanda kirişlemenin üstten yapıldığı ${ }^{20}$, düz tavan ortada tekne tonoz şeklinde göbek, düz tavan ortada kubbe, düz tavan çıtalı göbek, çıtakâri tavan ortada çıtakâri göbek, çıtkâri tavan ortada kubbe, kademeli tavan şeklinde düzenlemeler karşımıza çıkmaktadır.

İncelenen örneklerden desteksiz ahşap tavanlı Câmilerde iç örtü düz tavan şeklindedir. Düz tavanlar, geleneksel Türk evlerinde de çok yaygın olarak uygulanmıştır. Bu tavanlar; kirişlemenin altına perdahlı veya düz tahtaların, uzunlamasına düzgün bir yüzey oluşturacak biçimde çakıl

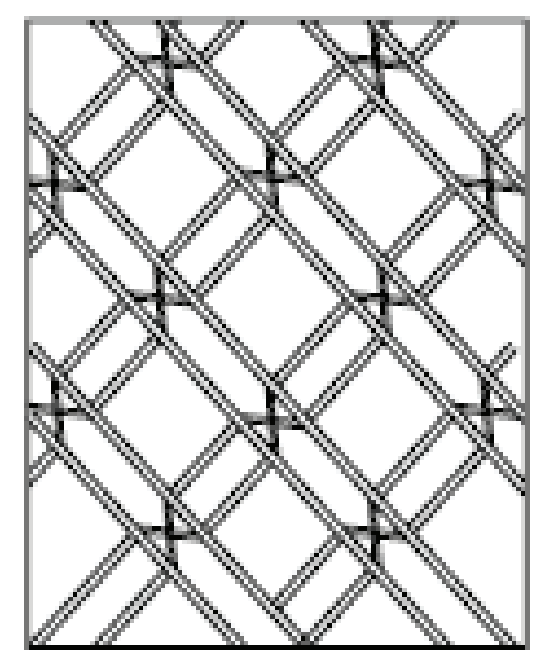

masıyla elde edilir. Daha sonra bu yüzey çeşitli süsleme teknikleriyle bezenebilir. Bu teknikte yapılan tavanlarda kirişlemenin alt kaplandığı için kirişleme görünmez. Dolayısıyla düzgün bir görünüm elde edilir. Duvar ile bütünlüğünün sağlanması için ince pervazlarla çevrelenebilir. Çoğunlukla yapıldığı döneme, konumuna ya da ustanın süsleme anlayışına göre, çıta ve tahtalarla geometrik şekiller oluşturularak, $\mathrm{S}$ ve $\mathrm{C}$ kıvrımı parçalarla, aplike elemanlarla çok farklı şekillerde süslendikleri görülür. Bazı örneklerde ise düz bırakılan zeminin ortasına bir göbek oluşturularak sade bir süsleme yapılmıştır.
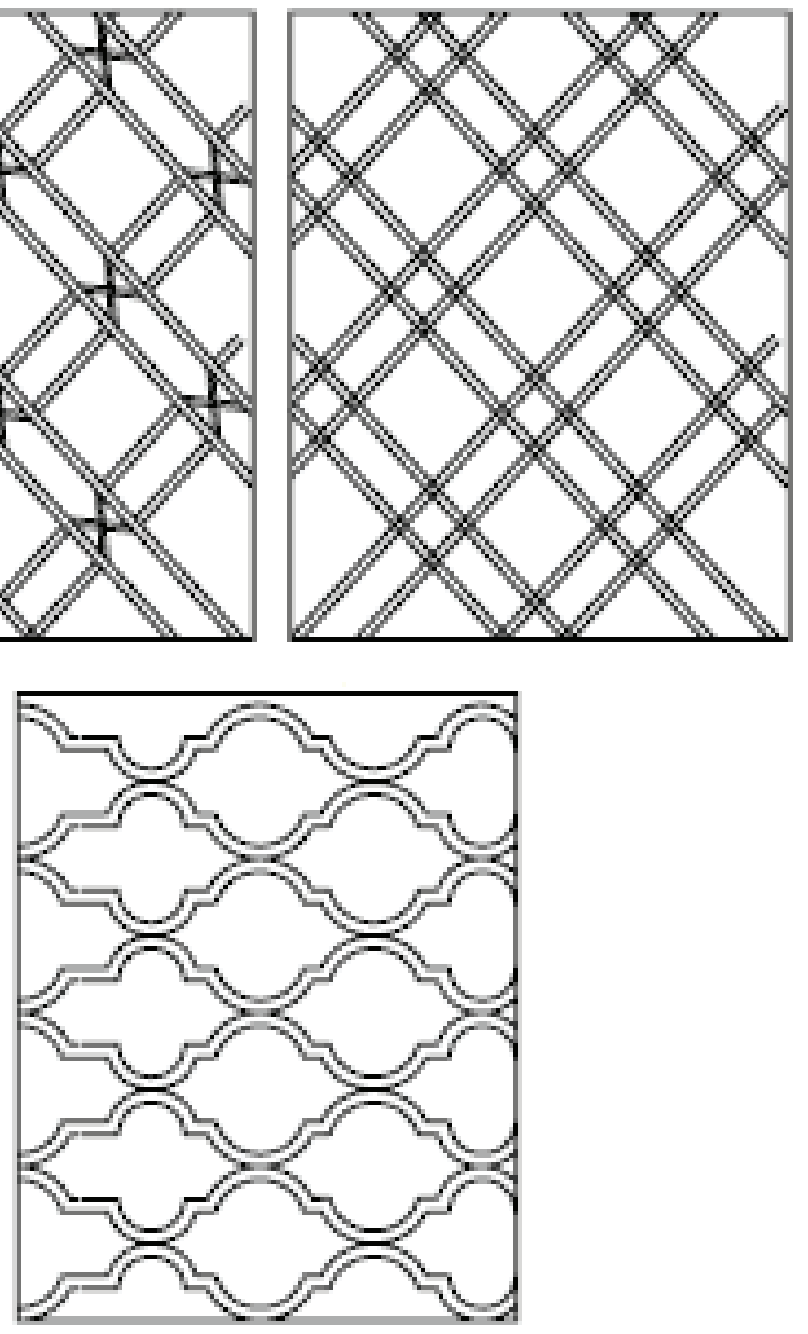

Çizim 1. Sık kullanılan çıtakâri tavan uygulamaları (Yıldırım ve Hidayetoğlu, 2006: 336).

20. Kale Cevher Paşa Câmi . 
İncelen toplam otuz beş câmide tamamen sade düz çıtalı tavanlar mevcuttur. Denizli İnce Karalar Câmi'nde göbekte ve köşelerde kalemişi süslemelere rastlanırken, Güney Dere Câmi'nde düz tavanın tam ortasında çıtalarla oluşturulmuş baklava dilimi şeklinde basit bir göbek dikkati çeker. Çivril Gümüşsu Dere Câmi'nde ise tavan çıtaları çaprazlama çakılarak ortada oldukça geniş, sekizgen bir göbek oluşturulmuştur. Dere, Sarayköy Çarşı Câmi ile Babadağ Yukarı Kuzere Câmilerinde tavan çıtakârî olarak yapılmış ve ortada tavan yüzeyinden dışa taşkın, yine çıtalarla oluşturulmuş geometrik desenli bir göbek mevcuttur.

Düz ahşap tavanlı Câmilerden sekizinde orta sahınların üzeri kademeli tavan şeklinde düzenlenmiştir. Bekilli Çoğaşlı Köyü Câmi (1743 M./H.1156), Baklan Boğaziçi Çalkebir Köyü
Eski Câmi'nde (1774-75 M./H.1186), Güney Belenardıç Köyü Câmi 1884 M, Baklan Tekke Câmi 18. Yy. sonu 19. yy başı, Çivril Savran Köyü Serbanşah Câmi (18. Yüzyılın üçüncü çeyreği), Acıpayam Yazır Çarşı Câmi (1802 M./H.1217), Çivril Bayat Köyü Câmi (18.yy.sonu 19.yy başı) Çal Kocaköy Şalvan Câminde (18.yy-sonu-19.yy başı), orta sahınların üzeri tekne tavan da denilen kademeli tavan şeklindedir.

Serbanşah ve Çal Kocaköy Şalvan Câmilerinde ise merkezden dışa doğru dağılan yuvarlak formlu tavan göbeği ve çevresinde baklava dilimi çıtalarla süsleme yapılmıştır. Güney Belenardıç Köyü Câmi (M.1884/R.1300) Baklan Tekke Câmi'nde (18.yy-sonu-19.yy başı) ise, ters tavan şeklinde olup üst örtü dıştan kırma kiremit çatılıdır. ${ }^{21}$
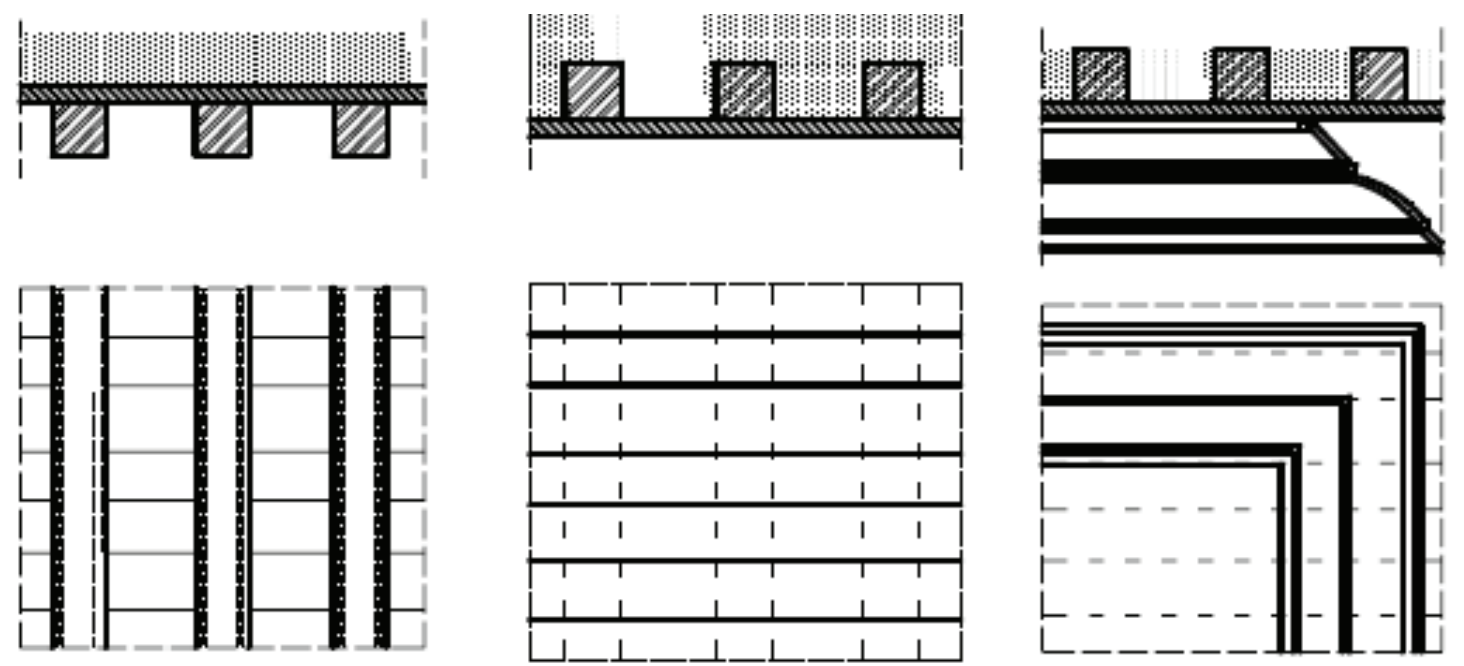

Çizim 1. Sık kullanılan çıtakâri tavan uygulamaları (Yıldırım ve Hidayetoğlu, 2006: 336).

21. Ters tavan, en yalın ve süslemesiz tavan şeklidir. Bu tür tavanlar kirişler üzerine, ince lama şeklinde merteklerin yan yana sıralanmasıla ya da hasır ve buna benzer malzemelerin kirişlerin üzerine serilmesiyle oluşturulur. (Yıldırım ve Hidayetoğlu, 2006: 335). 
Düz tavanlı Câmilerden Çarşı, Dedeli, Kavaklı, Tavas Mestanağa, Yukarı Babadağ Hamidiye, Kızılcabölük Hanönü (İnce, 2006: 169), Acıpayam Apa Köyü (Pektaş, 2003b: 430),Tavas Aydoğdu Köyü, Acıpayam Ovayurt Taraş Köyü, Sarayköy Hükümetönü, Tavas Avdan Baba, Tavas Ali Ağa, Serinhisar Ağalar (Hacı Hamza), Câmilerinde olmak üzere toplam on dört câmide düz tavanın ortasında tekne tonoz şeklinde çökertme göbekler vardır.

Düz ahşap tavanlı Câmilerin bazılarında da çatı aralığının elverdiği ölçüde gizli ahşap kubbelere yer verilmiştir. Babadağ Aşağı Tepeardı Câmi, Tavas Ebubekir Câmi, Acıpayam Yassıhöyük Eski Câmi, Yatağan Teke Müsellim Câmi, Denizli merkezde Hacı Kaplan ve Hatipoğlu Câmileri ile Çardak Gemiş ve Söğüt Köyü Câmileri, Çivril İğdir Köyü Câmi ve Sarayköy Hisarköy, Sarayköy Hasköy Câmileri (Pektaş, 2007: 145) ile Akköy Yukarı Câmi (İnce, 2007: 476) olmak üzere toplam on bir câmide ahşap tavan ortasında kubbeler mevcuttur.

Sadece bir yapıda ise düz ahşap tavanların arasında kare planlı bağdadi beş tonozun yerleştirildiği Çal Çarşı Câmi (1903) farklı bir örnek olarak karşımıza çıkmaktadır.

Değişik yörelerde ahşap destekli ahşap tavanIı Câmilerde sembolik kubbelerin kullanıldığı örneklere rastlanmaktadır. Örneğin Çarşamba Paşa Yazı Köyü Câminde harimin düz ahşap tavanı ortasında, dışarıdan belli olmayacak biçimde çatı arasına gizlenmiş yaklaşık $3 \mathrm{~m}$ çapında süsleme amaçlı yapılmış ahşap bir kubbe bulunmaktadır (Nefes,2010:397). Yine Ordu'da Atik Ibrahim Paşa (1801M./H.1216), Hamidiye Câmi 1889 M. /H.1307) Aziziye Câmi (1892 M./H.1310) Câmileri (Baş, 1994:261) Artvin Muratlı Merkez Câmi (1262/1846 M. düz ahşap tavanlarının ortasında bağdadi kubbeler yer almaktadır (Aytekin, 1998: 42).

Kubbeli Câmilere bakıldığında Honaz Sultan Murad Câmi, Çivril Dedeköy Emirhisar Câmi ve
Tavas Hırka Köyü Câmileri tek kare mekân üzerinde kubbe örtülü yapılardır. Her üç yapıda da kubbe sekizgen diştan sekizgen kasnağa oturmaktadır. Honaz Sultan Murad Câmi bugün büyük ölçüde harap vaziyettedir. İçte kubbeye geçişler mukarnas sıraları ile oluşturulmuş 16gen bir kasnak ve sivri kemerli tromplarla sağlanmıştir.

Dedeköy Câmi'nde ise yine kubbeye geçişler içeride sivri kemerli büyük tromplarladır. Tromplar arasında da üçgen alanlar mevcuttur. Kemer aralarına gergi kirişleri yerleştirilmiştir. Kasnakta yuvarlak kemerli nişler içerisinde yine yuvarlak kemerli pencereler vardır.

Tavas Hırka Köyü Câmi'nde de kubbeye geçişler oldukça büyük yivli tromplarladır. Kasnaktaki sivri kemerli pencereler ise sağır pencere şeklindedir. 1429 tarihli Edirne Şah Melek Paşa Mescidi, Edirne Ayşe Kadın Câmi (1468), Akşehir Hasan Paşa Câmi (1508), Ankara Cenabi Ahmet Paşa Câmi (1565) kubbeye geçişin yivli tromplarla sağlandığı yapılara örnektir. Görüldüğü üzere 15. ve 16. Yüzyıl özelliği olarak karşımıza çıkmaktadır Duvarlara gelen yükleri ise sivri boşaltma kemerleri karşılamaktadır. ${ }^{22}$

Denizli Kayalık Müftü Câmi ile Çivril Çarşı Câmi'nde de kare mekânları örten birer bağdadi kubbe mevcuttur. Çivril Çarşı Câminde de dıştan sekizgen kasnak ve her cephede sivri kemerli birer pencere mevcuttur. Kubbe içerde köşelerde yuvarlak kemerli tromplara oturmaktadır.

Kayalık Câmi'nde kubbenin oturduğu on altgengen kasnağın her cephesinde bir pencere mevcuttur. Kubbe içerde güneyde duvarlar tarafindan, diğer üç yönde sekiz ahşap destek tarafindan taşınmakta olup, destekler yuvarlak bağdadi kemerlerle birbirine bağlanmaktadır. Batılılaşma Döneminde örnekleri görülen kârgir beden duvarlı, üst örtüde bağdadi tarzda kub-

22. Konuyla ilgili olarak Bkz. Ayverdi,1989:418; Yüksel, 1986:328; Aslanapa;1986:328). 
beli inşa edilen etrafi tonozlu yapılar mevcuttur. Bunun erken örneklerine M.1590 /H.1000 tarihli İstanbul Takyeci İbrahim Ağa Câmi, 1791-92 M./H.1206 tarihli Soma Hızır Bey Câmi (Kuyulu, 1990: 108) ve 1864-65 M./ H. 1281 tarihli Kırkağaç Çiftehanlar Câminde bu tür planlar görülür. Dedeköy Câminde kubbe dıştan sekizgen yayvan bir çat, Çivril Çarşı Câminde de sekizgen piramidal çatı ile örtülü olup kiremit kaplıdır. Denizli Kayalık Müftü ve Hırka Köyü Câmilerinin kubbeleri ise dışta kurşunla kaplıdır.

\subsection{Destek ve Taşıyıcılar}

Denizli'de incelen düz tavanlı Câmilerde üst örtüyü taşıyan duvarlardan başka on üç yapıda ahşap desteklerin taşıyıcı işlevi gördüğü tespit edilmiştir. Kullanılan destek türleri kare, yuvarlak ve sekizgendir. Kare şeklinde destek yalnız Ulukent ve Çal Çarşı (1903) Câminde kullanılırken, tümü sekizgen desteklere sahip tek yapı Bekilli Çoğaşlı Köyü Câmi'dir. (1743 M./H.1156). Güney Belenardıç Köyü Câmi'nde (1884) serbest olan üç destek sekizgendir. Acıpayam Yazır Çarşı Câmi (1802 M./H.1217), Çivril Serbanşah Câmi (18. Yılın üçüncü çeyreği), Kale Cevher Paşa Câmi (1819-20 M./H.1235), Baklan Tekke Câmi'nde (18.yüzyıl sonu-19.yy başı) desteklerin tümü yuvarlaktır. Düz tavanlı câmilerden on üç Câmide toplam yüz dört ahşap destek bulunmakta ve bunlardan otuz dokuzu kare altmış biri yuvarlak, dokuzu sekizgen biçimindedir.

Yapılardan sadece Çivril Savranşah Köyü Serbanşah Câminde (18. yüzyılın üçüncü çeyreği) yuvarlak şekilli, Kale Cevher Paşa Câminde (1854 M./ H.1251 ) kompozit, Bekilli Çoğaşı Köyü Câmi'nde (1743 M./H.1156) kare prizmal biçimli sütun başlığını andıran düzenlemeler mevcuttur.

18.yüzyılın ikinci yarısı ile 19.yüzyıl başı arasındaki tarihlerde inşa edilen söz konusu yapılarda kullanılan kare desteklerin kullanım oranı- nın yuvarlak desteklere göre daha az olduğu görülür. Bu da malzemenin doğal formunun bozulmadan kullanıldığına işaret etmektedir. Sadece Güney Belenardıç Köyü Câmi'nde onbir destek kare şeklindedir. Bu yapıdaki desteklerle ilgili bir farklılık da onbir desteğin tümünün duvarlara bitişik olmasıdır. Yapının benzer plan türlerinin aksine dört sahınlı olması da sonradan bazı müdahalelerin yapıldığına işaret etmektedir. Kare desteklerin kullanıldığı yapılarda az sayı teşkil etmesi bu yapıların belki de başlangıçta tümünün yuvarlak destekli olduğu, sayıca az olan kare desteklerin ise daha sonradan ilave edildiklerini düşündürmektedir.

Çivril Savranşah Köyü Serbanşah Câminde alt olan 0,30x0,33 m. çapındaki desteklerin yükseklikleri $3.89 \mathrm{~m}$. ile $3.98 \mathrm{~m}$. arasında değişmektedir. Acıpayam Yazır Kasabası Çarşı Câminde (1802 M./H.1217), 0,32x0,35 m.(10), Kale Cevher Paşa Câmi'nde 33×36cm. ölçülerinde (10), Baklan Tekke Câmi(18.yüzyıl sonu 19.yüzyıl başı.), (12) yuvarlak destek mevcuttur. Çivril Serbanşah, Kale Cevher Paşa(1819-20M./H.1235), Baklan Tekke, Bekilli Çoğaşlı Köyü (1893) Câmilerinde destekler tamamen duvardan bağımsızdır.

Destekler üzerinde başık, sadece Serbanşah ve Kale Cevher Paşa Câmi'nde görülmektedir. Serbanşah'da C-S kıvrımlı yuvarlak başlıklar yer almakta olup, başlıkların yüksekliği 0,18 m., en dar oldukları alt kısımda çapları 0,28 m., en geniş oldukları üst kısımda çapları 0,47m.dir (Mavuşoğlu, 2008: 13). Kale Cevher Paşa Câmi'nde ise kompozit başlık formunun ahşaba işlenerek kullanıldığı görülür. Câminin bulunduğu yerin bir Bizans yerleşimi olmasının bu tür etkileşimlerde rol oynayabileceği düşünülmektedir. Cevher Paşa Câminde başlıklar üzerine sonradan ilave edilen dikdörtgen prizma şeklinde yükseltilerin (0,50 m.) benzeri, Yazır Çarşı Câmindeki destekleri oluşturan tek parça ahşabın üstte yuvarlak bir silmeden sonra dikdörtgen prizma şekline 
getirilmesi ile sağlanmıştır. Çal Çarşı Câmindeki kare şeklinde desteklerin bir silmeden sonra kare prizmal şekilde bir başlık görünümünde sonlandırılması da buna benzer bir örnektir.

Destekler bizzat tarafimızdan tespiti yapılan, Kale Cevher Paşa, Yazır Beldesi Câmi, Baklan Boğaziçi Çalkebir Eski Câmi, Baklan Tekke Câmi, Bekilli Çoğaşlı Köyü Câmi ile Çivril Bayat Köyü Câmilerinde serbest profilli yastıklara otururken, Güney Belenardıç Câminde serbest profilli yastıklar yerine, kirişlerin destekler üstüne gelen kısmına profilli yastık görünümü verilmiştir (Resim 47).

Destekler Serbanşah Câminde sivri, Baklan Boğaziçi Çalkebir Eski Câminde sivri ve Bursa kemeri, Çal Şalvanköy Câminde taşıyıcı işlevi olmayan dekoratif üç dilimli yuvarlak kemerlerle bağlanmıştrr. Bozkurt Baklankuyucak Köyü Câminde de önceden üç dilimli kemerler varken onarımdan sonra bunun yerine basit kemerler yapılmıştır. Baklan Çataloba Köyü Câminde destekler doğrudan kirişlere oturmaktadır. Tüm yapılarda destekler kaidesizdir.

Düz tavanlı veya kubbeli câmilerde üst örtüyü taşıyıcı elemanlardan biri de duvarlardır. Gerek ahşap destekli, gerekse içerde destek kullanılmayan Câmilerin duvarlarında yapı malzemesine bakıldığında kabayonu, kesmetaş, moloz taş, ahşap, kerpiç malzemenin ahşap hatillarla desteklenerek yığma duvar şeklinde yapıldığı anlaşılır. Denizli merkezde bulunan Öküzbatt Mescidi (Resim 47a-b), İncekaralar Câmi, Kiremitçi Mahallesi, Odun Pazarı, Akkonak Mahallesi, Saraylar Mahallesi Câmilerinde duvar örgüsünde su basman seviyesine kadar moloz taş, üzerinde ahşap çatkı arası kerpiç örgü tekniğinin uygulandığı görülür.

Yine Baklan Boğaziçi Çalkebir Köyü Eski Câmi,

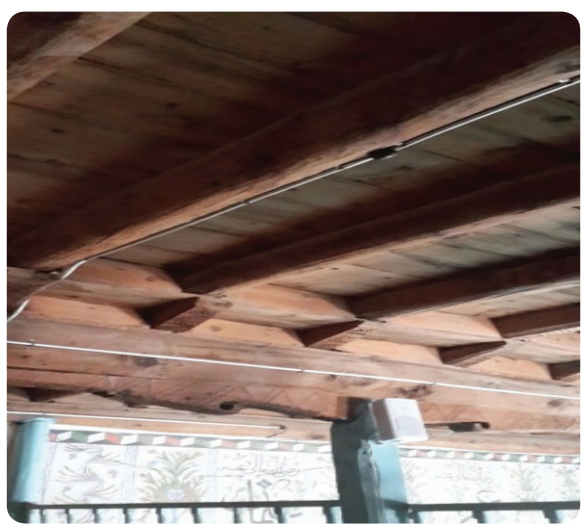

Resim 47. Güney Belenardıç Köyü Câmi ( 29 Mart 2017)
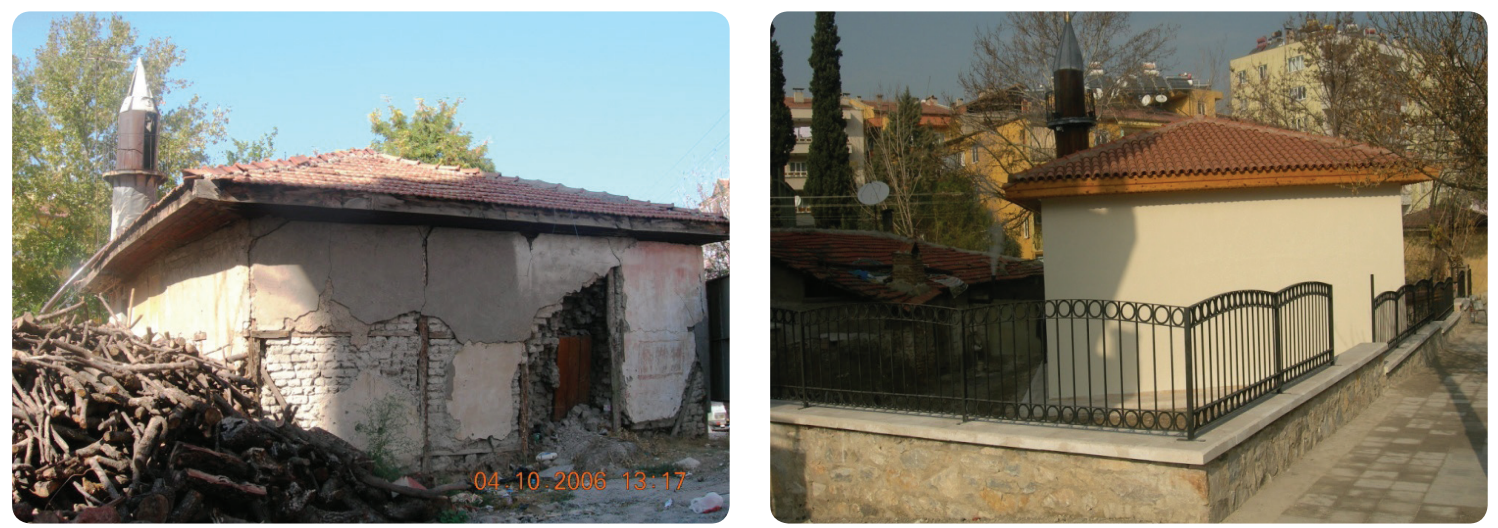

Resim 47a-b. Öküz Batt Mescidi duvar örgüsü onarım öncesi ve sonrası (VGMA,20:2006). 
Bozkurt Baklankuyucak Câmi, moloz taş su basman seviyesine kadar kullanılmış olup, kerpiç malzeme ve aralarda ahşap hatillarla desteklenerek yığma olarak edilmiştir. Çivril Bayat Köyü Câminde de duvarlarda tamamen kerpiç kullanılmıştır.

Baklan Çataloba Köyü Câmi'nde temelden $0,30 \mathrm{~cm}$. kadar yükseklikte kaba yonu taşla inşa edilen duvarlar kerpiç malzemeyle devam ettirilerek aralarına ahşap hatıllar yerleştirilmiştir. Tavas Ulukent Câmi Çal Kocaköy (Şalvan) Câmi ile Güney Belenardıç Köyü, Çoğaşlı Köyü, Çal Kuyucak Köyü, Yazır Köyü Çarşı (0,87m.), Baklan Tekke Câmi'nde yapının tamamında moloz taş kullanılmıştır.

Serbanşah Câmi'nde duvarlar pencere alt seviyesine kadar içten moloz taş ve tuğla, dışta ise muntazam blok taşlardan örgülüdür. Bu kesimden yukarısı ise kerpiç örgülü olup, aralarına yatay yerleştirilmiş ahşap hatllarla inşa edilmiştir. Duvar kalınlığı $0.70 \mathrm{~m}$. ile $0.74 \mathrm{~m}$. arasında değişmektedir.

Kale Cevher Paşa Câmi duvarlarında kaba yonu taş, moloz taş, pencerelerde ki atkı taşlarıyla mihrapta kesme taş kullanılmış olup duvar kaıınlığı yapının tüm duvarlarında 0,84 m.'dir.

Kubbeli Câmilerden Honaz Sultan Murad Câmi (15.-16.yy), Çivril Dedeköy Câmi (15-16.yy), (1,46-1,50 cm) ve Tavas Hırka Köyü Câmilerinde (1860-61 M./H.1277) duvar kalınlıkları (1,471,67 cm.) düz ahşap tavanlı câmilere göre daha fazladır. Tavas Hırka Köyü Câmi geç döneme tarihlenmesine rağmen diğer iki yapıyla karşılaştrıldığında plan, malzeme ve teknik bakımdan benzerlikler göstermekle birlikte, daha erken dönem özellikleri yansıtır. Kullanılan malzeme ise kaba yonu, devşirme blok taş ve mermer ve tuğladır. Honaz Sultan Murad Câmi'nde duvarlarda kaba yonu, moloz taş, tuğla, tromplarda tuğla, kasnakta ve kubbede dönüşümlü kaba yonu ve tuğla malzeme kullanılmıştır. Dede Köy
Câmi'nde duvarlardaki malzeme aynı olmasına rağmen kubbe, kemer ve tromplar tuğladır. Kasnakta ise tuğla ve kaba yonu taşın dönüşümlü kullanılması yönünden benzeşir. Tavas Hırka Köyü Câmi'nde de duvarda kullanılan malzemeler aynı olmasına rağmen kasnakta moloz taş kullanımı dikkati çeker. İçyapıda duvarlar sıvalı ve badanalı olduğu için malzeme kullanımı açısından bir şey söylemek mümkün olmasa da tromp ve kemerlerde tuğla kullanılması ihtimali yüksektir.

Çivril Çarşı Câmi ile Denizli Kayalık Müftü Câmi duvarlarda kesme taş, kubbesinin ise bağdadi olarak yapılması bakımından birbirine benzerler. Ancak Kayalık Müftü Câmi'nde kubbeyi üç taraftan kuşatan bağdadi kemerli ve tonozlu mekânlar vardır.

Denizli ve çevresinde bulunan düz tavanlı ve kubbeli Câmilerin inşaat malzemesinin seçiminde, yörede kullanılan ve kolay bulunabilen malzemenin tercih edildiği, özellikle Denizli merkezde temelde moloz taş üzerine ahşap çatkılı kerpiç duvarların, Babadağ'daki eserlerde kesme taş, Çal, Çivril ve Tavas yöresindeki eserlerde ise moloz taş ve kerpiç, Buldan ve Güney'de bulunan yapılarda moloz taş ve kaba yonu taş kullanımının yaygın olduğu dikkati çekmektedir. Kubbeli yapılarda ise kesme blok taş, moloz taş, devşirme mermer, kemer kubbe ve tonozlarda tuğla malzemenin kullanıldığı, Kayalık Müftü ve Çivril Çarşı Câmi'nde bağdadi kubbe ve kemerlerde, Çal Çarşı Câmi'nde tonozlarda ise ahşap kullanılmıştır.

\section{Sonuç}

Denizli ve çevresinde yer alan câmilerden belgeleri bunulan genelde vakıf eseri olan yetmiş altı câminin yapı elemanları açısından değerlendirilmesinin yapıldığı bu çalışmada yapılar harim bölümleri örtü, destek ve taşıyıcılar açısından ele alınmıştır. Söz konusu çalışma yeni yapıların da tespiti ile yeni bilgi ve belgeler ışı- 
ğında önceki ve onarım sonrası durumlarının yapı elemanları açısından karşılaştırılmalı olarak değerlendirilmesi bakımından önemli bir çalışmadır.

Düz ve kubbeli câmiler olarak yapılan ayrıştırmada yetmiş bir düz tavanlı beş kubbeli yapı tespit edilmiştir. Düz tavanlı câmilerde örtü sistemi genellikle dıştan kırma çat şeklinde olup, kiremit kaplıdır. İçte ise çoğu tamamen düz tavan şeklinde olan otuz beş, ahşap tavan ortasında çıtalı göbekli dört, tekne biçimli çökertme göbekli on bir, düz kubbeli on üç, düz tonozlu bir, ters tavan şeklinde olup ortası kademeli sekiz câmi şeklinde gruplandırılmıştır.

Bu yapılardan harim içinde tavanı taşıyan desteklere sahip on üç câmi mevcut olup, kare, silindir ve çokgen desteklerin kullanıldığı dikkati çeker.

Malzeme olarak genellikle temelde moloz taş ve üzeri ahşap çatkılı arası kerpiç kullanımı dikkati çeker. Ancak moloz taş ve ahşap hatıl, kerpiç ve ahşap hatıl, kaba yonu malzemelerle yapılan yığma duvarlar da mevcuttur. Malzeme kullanımı yörelerde kolay bulunabilir malzemeye göre ağırlık kazanmıştır.

Beş adet kubbeli câmiden ikisinde kubbe bağdadi olarak yapılmıştır. Birinde kesme taş diğer ikisinde tuğla kullanımı dikkati çeker. Kubbeye geçişler tromplarla yapılmış olup, düz tavanlılara göre oldukça kalın duvarlar kubbeyi taşımaktadır.

En özgün örnek ise Denizli merkezdeki Kayalık Müftü Câmi olup, güneyde duvarlara oturan bağdadi kubbenin üç yanında beşik tonozlu mekânlar yer alır. Bağdadi kubbeli iki yapıda da beden duvarları taşla inşa edilmiştir.
Denizli ve yöresinde yapı elemanları açısından değerlendirmeye tabi tutulan bazı câmilerin erken döneme tarihlenen kubbeli, çoğunun ise geç dönemde inşa edilmiş ahşap tavanlı, ahşap destekli yapılardan oluştuğu dikkati çeker.

Ahşabın kolay bulunabilir bir malzeme olması gibi temel nedenler de göz önüne alındığında başta Karadeniz olmak üzere ülkemizde birçok yörede değişik tiplerde inşa edildiği gibi ahşap tavanlı câmilerin geç dönemlerde Denizli ve yöresinde de inşa edildiği anlaşılmaktadır.

Söz konusu çalışma, 13.- 19. yüzyıllar arasında Denizli ve yöresinde inşa edilen, literatürde yer alanlardan başka, tarafimızdan yeni tespiti de yapılan 71 ahşap tavanlı ve 5 kubbeli câminin bugüne kadar yayınlanmamış arşiv bilgileri (yapılan onarımlar, yapılarla ilgi hazırlanan raporlar ve yapılarla ilgili vakfiyeler) ışığında bütüncül bir anlayışla yapı elemanları açısından değerlendirildiği ve bilim alanına sunulan derli toplu bir çalışmadır.

Bazı yapıların son kez ziyaret edilmesi sırasında vakıf eseri câmilerin aslına uygun onarıldığı, ancak Çataloba Köyü Câmi gibi bazı yapıların yıkılıp yerine yenisinin yapıldığı veya Taraş Köyü Câmi gibi ahşap tavanların onarım sırasında asma tavan altında bırakıldığı, nadir kalan son dönem örneklerde aslına uygun onarımlar yapılmadığı, bilinçsiz yapılaşma sonucu kaybolmaya yüz tuttuğuna şahit olunmuştur.

Çoğu geç dönem örnekleri olan bu yapıların gelecek kuşaklara sağlıklı bir şekilde aktarıması açısından, yörenin tamamen taranarak (vakıf kökenliği vs) bir envanter oluşturulması ve tamiratları veya yeniden inşâları sırasında denetimsiz bırakılmamaları gerektiği düşünülmektedir. 


\section{Kaynaklar}

\section{Arşiv Kaynakları}

Vakıflar Genel Müdürlüğü Vakıf Kayıtlar Arşivi VGMA Def. 210: 30-229; Def. 735: 119-49.

Sanat Eserleri Dairesi Başkanlığı Arşivi

VGMA, Tescil Fişi 200001005-TF001)Hasan Yüksel ve Nejdet Beşbaş.

VGMA, Envanter Fişi 09.04.2006)Nesrin Karabay ve Cevdet Sevinç.

\section{Araştırma ve İnceleme Eserler}

Arel, Ayda (1990). "Ege Bölgesi Ayanlık Dönemi Mimarisi:1989 Dönemi Yüzey Araştırmaları". VIII. Araştırma Sonuçları Toplantısı. Ankara. s. 1-24.

Aslanapa, Oktay (1986). Osmanlı Devri Mimarisi. İstanbul.1986.

Aytekin, Osman (1998). "Serhat Boylarında Bir Osmanlı Dönemi Yapısı Muratlı Merkez Câmii". Erzurum Atatürk Üniversitesi Güzel Sanatlar Enstitüsü Dergisi, 4: 37-47.

Ayverdi, Ekrem Hakkı (1989). Osmanlı Mimarisinde Çelebi ve II. Sultan Murad Devri. İstanbul. Baykara, Tuncer (1969). Denizli Tarihi. İstanbul. Baykara, Tuncer (1999) "Denizli”. İslâm Ansiklopedisi, C.9: s. 155-159.

Baş, Ali (1994). "Ordu'da Osmanlı Câmileri", Konya Selçuk Üniversitesi, Sosyal Bilimler Dergisi, 3, 261-284.Konya.

Cirtil, Saim (2006). "Denizli Türbeleri” Uluslararası Denizli ve Çevresi Tarih ve Kültür Sempozyumu Bildirileri,(6-7-8 Eylül). Denizli. C. II: s.195-205.

Cirtil, Saim (2007). "Çivril Bayat Köyü Câmi” Sanat Tarihi Araştırmaları, Haşim Karpuz'a Armağan. Konya. s. 115-124.

Çakmak, Şakir (1991). Denizli ili'ndeki Türk Anıtları (Câmiler). Ege Üniversitesi, Sosyal Bilimler Enstitüsü, Arkeoloji ve Sanat Tarihi Ana Bilim Dalı, Yüksek Lisans Tezi, İzmir.
Darkot, Besim (1955). “ Denizli”. İslam Ansiklopedisi. C. III. İstanbul. s. 527-531.

Erdemir,Yaşar, (1999), Beyşehir Eşrefoğlu Süleyman Bey Câmi ve Külliyesi. Beyşehir Vakfi Yayınları. Beyşehir.

Ersoy, Bozkurt (2012). "Kale-i Tavas (Tabae)". Ege Üniversitesi Arkeoloji Kazıları İzmir. s. 415-438.

Eskici, Bekir (1998). Ankara Mihrapları, Ankara Üniv. Sosyal Bilimler Enstitüsü Sanat Tarihi Anabilim Dalı (Yayınlanmamış Doktora Tezi). Ankara. Gökçe, Turan (2000). XVI. ve XVII. Yüzyıllarda Lâzıkıyye Kazası. Ankara.

İnce, Kâsım (1999). "Vakıflar Genel Müdürlüğü Arşivi'ndeki Babadağ’a Ait Vakfiyeler ve Babadağ'daki Türk Eserleri”. I. Babadağ Sempozyumu. Denizli. S. 468-508.

İnce, Kâsım (2001). "Yukarı Câmii/Akköy-Denizli”. Yüzüncü Yıl Üniversitesi Sosyal Bilimler Enstitüsü Dergisi, 2: 65-79.

İnce, Kâsım (2007). "Tavas ve Çevresindeki Osmanlı Mimarî Eserleri". Uluslararası Denizli ve Çevresi Tarih ve Kültür Sempozyumu 2. Denizli. S. 164-173.

Kuran, Apdullah (1972). "Anadolu'da Ahşap Sütunlu Selçuklu Mimarisi”. Malazgirt Armağanı. Türk Tarih Kurumu Yayını, Ankara. s. 179-186.

Kuyulu, İnci (1990). "Çiftehanlar Câmi". Arkeoleoji Sanat Dergisi, 5: s.103-115, İzmir.

Kütükoğlu, Mübahat (2002). XVI. Asırda Tavas Kazası. İstanbul.

Mavuşoğlu, Nazlı İpek (2008). Savranşah Köyü Câmi Restorasyon Projesi. Yüksek Lisans Tezi, İstanbul Teknik Üniversitesi Fen Bilimleri Enstitüsü, İstanbul.

Nefes, Eyüp (2020). “Çarşamba'da Yıkılmak Üzere Olan Ahşap Câmilerden Biri: Paşayazı Köyü Câmi", Uluslararası Sosyal Araştırmalar Dergisi The Journal of International Social Research Volume: 3 Issue: 14 Fall, s.385-389. 
Önge, Yılmaz (1975). "Selçuklularda ve Beyliklerde Ahşap Tavanlar". Atatürk Konferansları V, 1971-1972. Ankara. s.181-184.

Pektaş, Kadir (2003a). “Denizli Çevresindeki Türk Dönemi Tarihi Eserleri Üzerine (About Historical Artifacts of Turkish Period Around Denizli)", Uluslararası I. Denizli ve Çevresi Tarih ve Kültür Sempozyumu, Bildiriler 2. Isparta. s. 145-150.

Pektaş, Kadir (2003b).“Acıpayam ve Çevresindeki Türk Dönemi Eserlerinden Bir Kesit", I.ACIpayam Sempozyumu. Denizli. s.422-452.

Şimşek, Celâl (2000). Antik Lycos Vadisi'nde 2000 Yıllık Inaçlar. Denizli.

Toker, Turan (1941). "Frigya Baş Piskoposları". İnanç Dergisi, 54: s.23-35.

Uysal, Zekiye (2001). Ankara Mescitlerinde Kalem İşi Süslemeler (XIV.-XV. Yüzyıl). ÇÖMÜ Sosyal Bilimler Enstitüsü, Sanat Tarihi Anabilim Dalı, Yayınlanmamış Yüksek Lisans Tezi. Çanakkale.
Uzunçarşılı, İsmail Hakkı (1929). Kitâbeler II. İstanbul.

Yavuz, Mehmet (2009).“Doğu Karadeniz Köy Câmilerinde Bezeme Anlayışı". Uluslararası Sosyal Araştirmalar Dergisi, The Journal of International Social Research,Volume 2/6 Winter, Samsun. s. 306-322.

Yıldırım, K. Hidayetoğlu, M. Lütfi (2006). “Geleneksel Türk Evi Ahşap Tavan Süsleme Özelliklerinin Yapım Tekniklerinin Çeşitliliği Üzerine Bir Inceleme", Uluslararası Geleneksel El sanatları Sempozyumu. İzmir, s. 332-341.

Yüksel, İ.Aydın (1983). Osmanlı mimarisinde II. Bayezid, Yavuz Sultan Selim Devri (886926/1481-1520). İstanbul Fetih Cemiyeti. İstanbul.

http://www.stad.com/index.php?city_ id=300374\#photos

http://www.pamukkale.gov.tr/DE/page/kultur_Câmi.html.18.11.2012. 